Mechanisms of Carbon and Nitrogen transformations in Forest floors of Beech-, Spruce- and Mixed Beech-Spruce-Stands

\author{
Dissertation
}

Zur Erlangung des Doktorgrades des Forstwissenschaftlichen Fachbereichs der Georg-August-Universität Göttingen

\title{
Vorgelegt von
}

Ali Bagherzadeh Chaharjouee geboren in Mashhad - Iran

Göttingen, Februar 2004 
D 7

1. Berichterstatter: Prof. Dr. F. Beese

2. Berichterstatter: Prof. Dr. A. Hüttermann

Tag der mündlichen Prüfung: 16.02.2004

erschienen als elektronisches Dokument:

http://webdoc.sub.gwdg.de/diss/2004/bagherzadeh/index.html 
TO:

MEHRNOUSH \& ALIREZA 


\section{Table of contents}

1 INTRODUCTION (BACKGROUND HYPOTHESIS) ..................................................................... 1

2. TEMPERATURE DEPENDENCE OF NET C-MINERALIZATION AND $\mathrm{N}_{2} \mathrm{O}$ EMISSIONS FROM THE FOREST FLOORS OF A TEMPERATE FOREST ECOSYSTEM ..................... 4

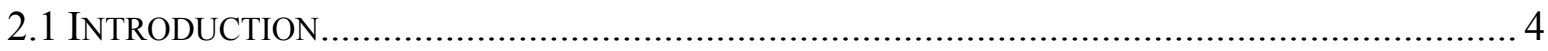

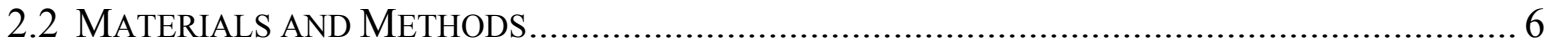

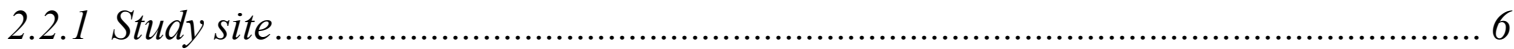

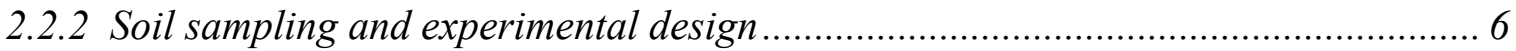

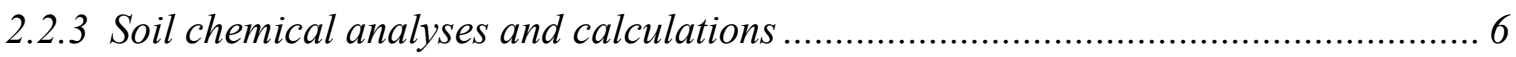

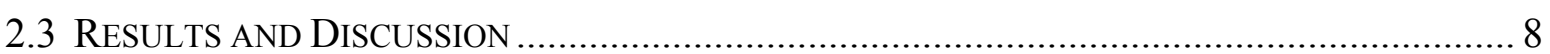

2.3.1 Impact of site on forest floors properties............................................................... 8

2.3.2 Temperature dependence of net $C$ mineralization............................................... 11

2.3.3 Temperature dependence of $\mathrm{N}_{2} \mathrm{O}$ emission rates............................................... 15

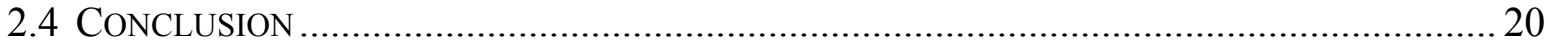

3. NITROGEN MINERALISATION IN $\mathrm{O}_{\mathrm{H}}$ HORIZONS OF BEECH, SPRUCE AND MIXED FORESTS AFFECTED BY TEMPERATURE AND SOIL MICROBIAL STATUS .............. 21

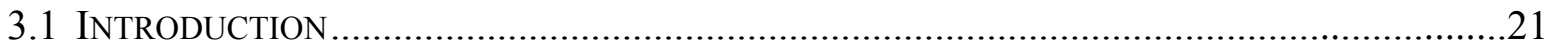

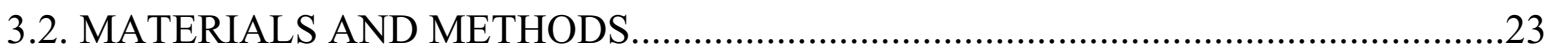

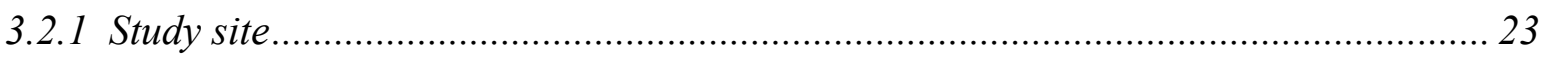

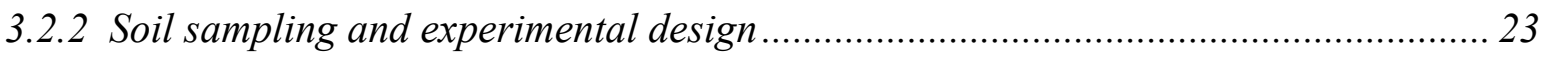

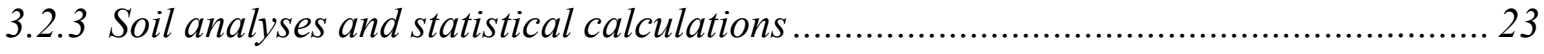

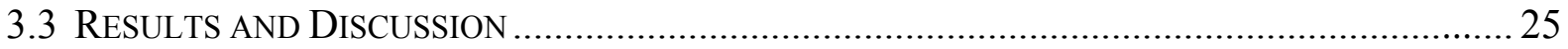

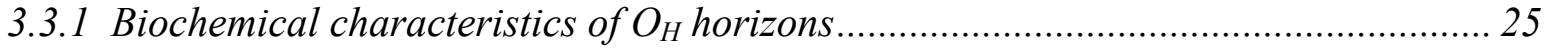

3.3.2 Net N-mineralization affected by litter quality and temperature .............................. 26

3.3.3 MiCROBIAL BIOMASS AND ERGOSTEROL CONTENT AFFECTED BY LITTER QUALITY AND

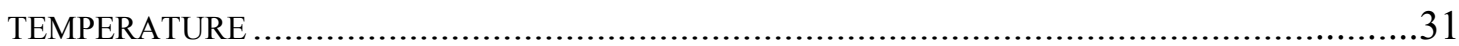

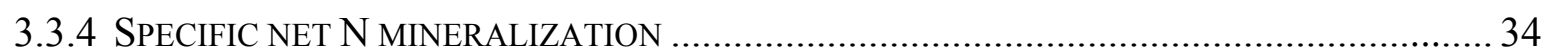

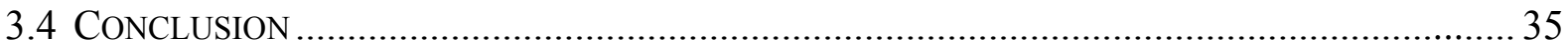

4. CARBON AND NUTRIENT STATUS OF BEECH SEEDLINGS GROWN ON THE

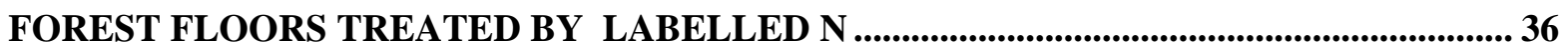

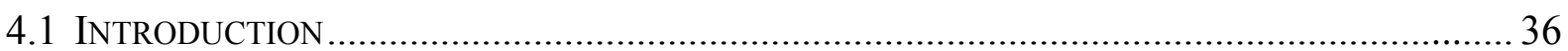

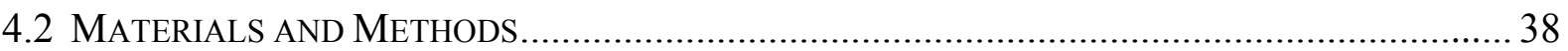

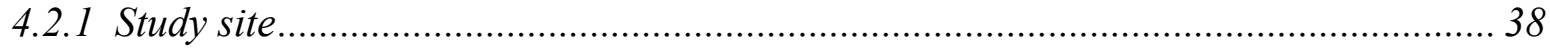




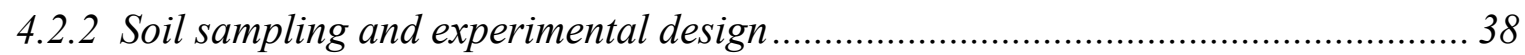

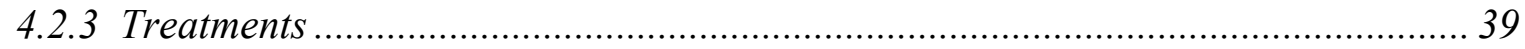

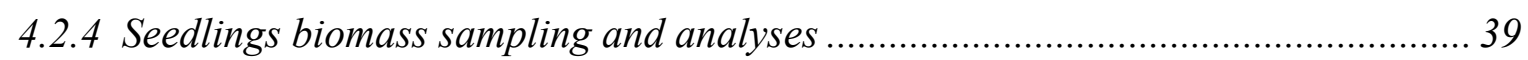

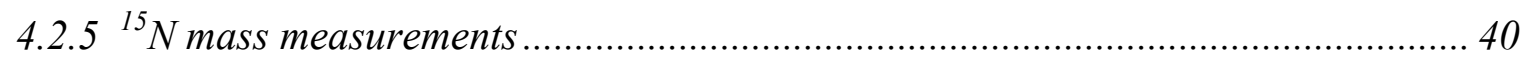

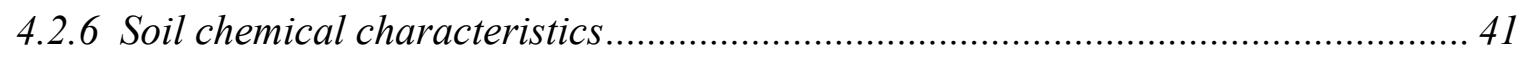

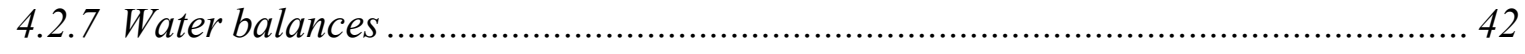

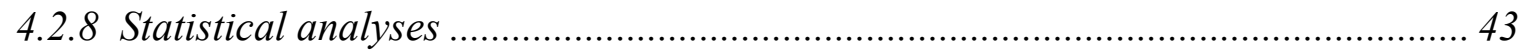

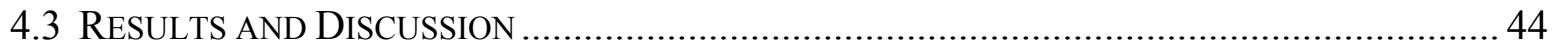

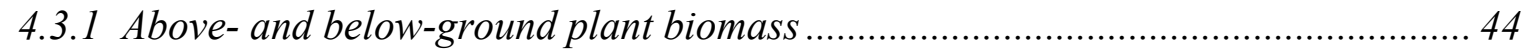

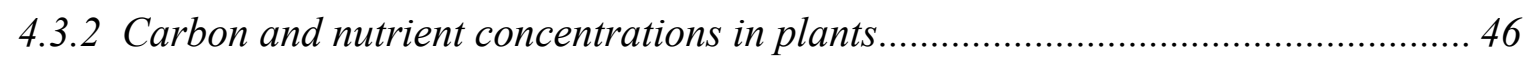

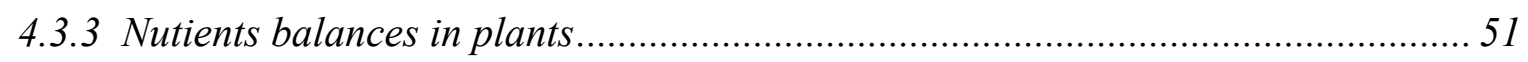

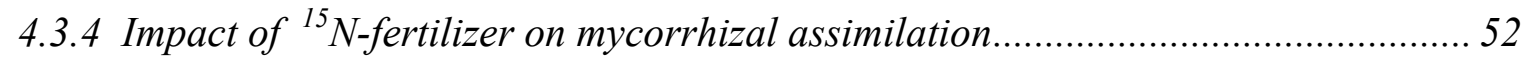

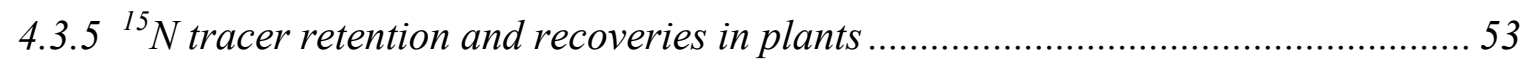

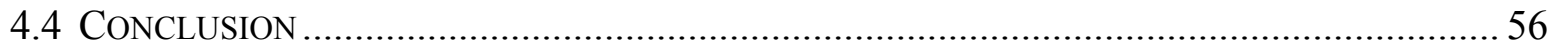

\section{NITROGEN TRANSFORMATION IN BARE AND BEECH COVERED FOREST

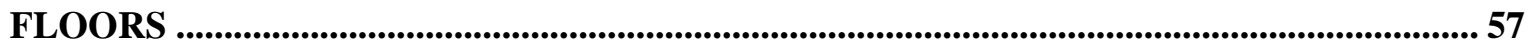

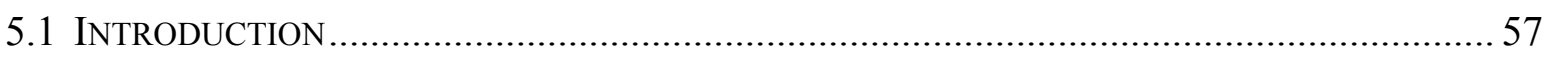

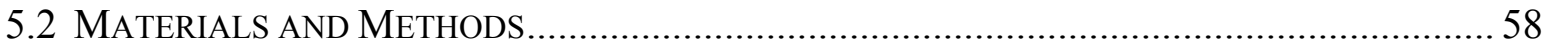

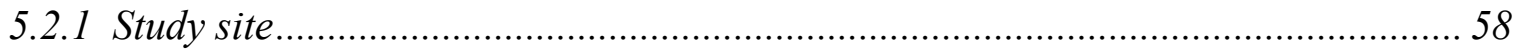

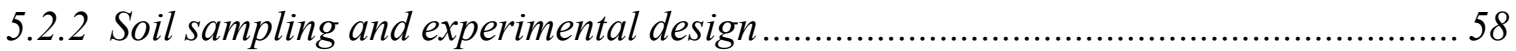

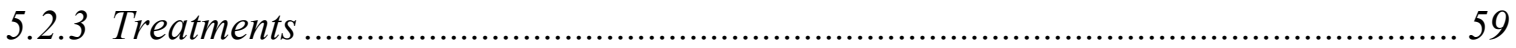

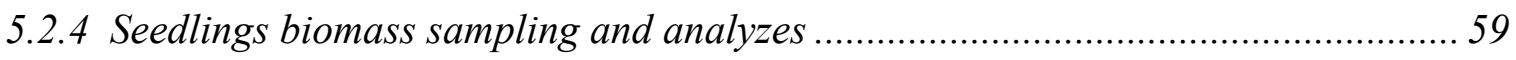

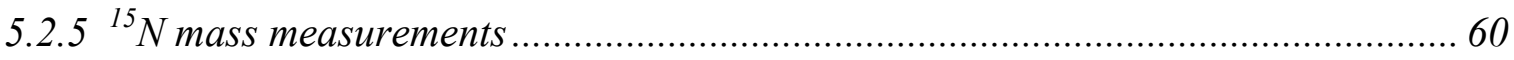

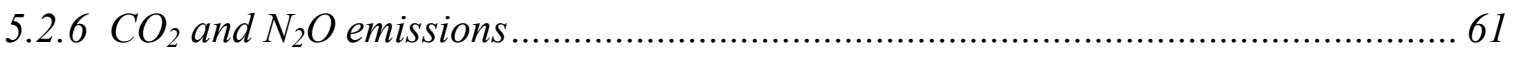

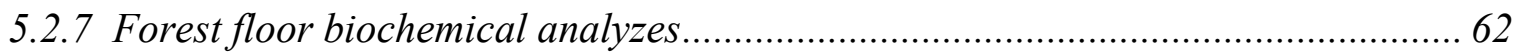

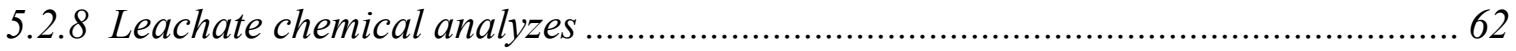

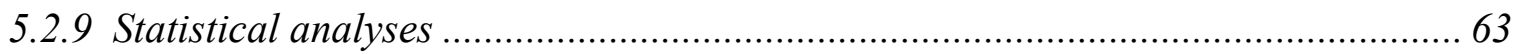

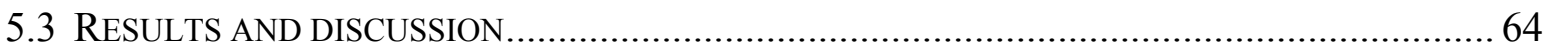

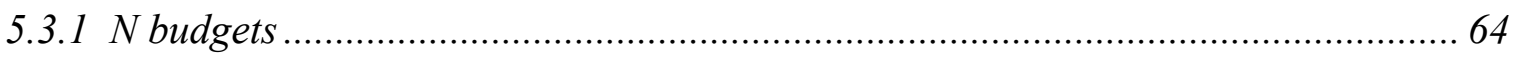

5.3.2 Impact of ${ }^{15} \mathrm{~N}$-fertilizer on nitrogen immobilization in forest floor ........................ 66

5.3.3 Impact of ${ }^{15} \mathrm{~N}$-fertilizer on dissolved organic carbon and nitrogen ....................... 68

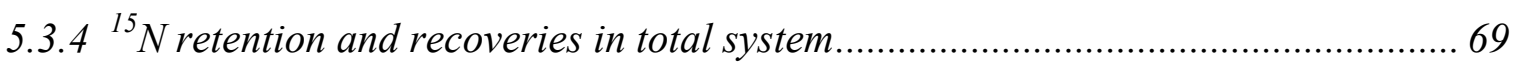

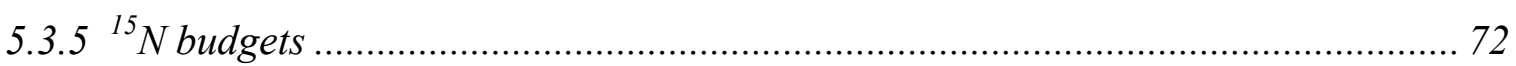




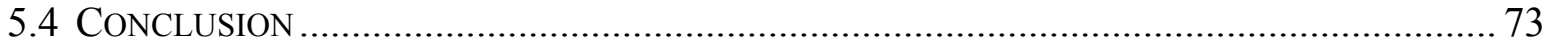

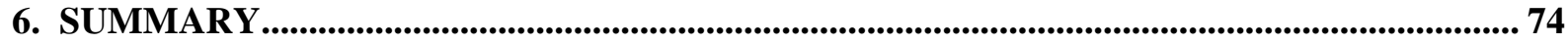

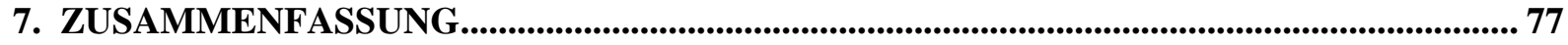

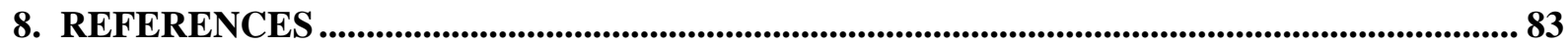

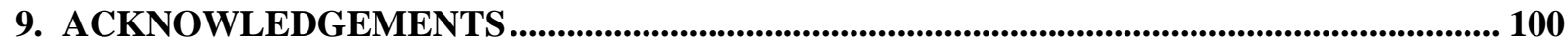




\section{Introduction (background hypothesis)}

Chronic Nitrogen deposition in many terrestrial ecosystems limits the net primary production and other processes involving the plants growth. In contrast to phosphorous, $\mathrm{N}$ is absent from most parent materials of the soils and must be accumulated from the N-pool of the atmosphere. Before the industrial age, rates of atmospheric $\mathrm{N}$ deposition on forests were exceedingly low and contributed insignificantly to the direct uptake by vegetation. Nevertheless, even low inputs of $\mathrm{N}$ over thousands of years can be accumulated in the soil and should more than account for the $\mathrm{N}$ quantities we observe in the soils today. In the past most of these inputs were as $\mathrm{NO}_{3}^{-}$, generated by lighting driven $\mathrm{N}_{2}$ oxidation, and as particulate organic $\mathrm{N}$ fixed by microorganisms. Nitrogen deposition in form of fertilizer, animal husbandry and fossil fuel combustion in the last century have significantly increased emissions of $\mathrm{NHx}\left(\mathrm{NH}_{3}\right.$ and $\left.\mathrm{NH}_{4}{ }^{+}\right)$and $\mathrm{NOx}\left(\mathrm{NO}\right.$ and $\left.\mathrm{NO}_{2}\right)$. Transport and transformations of NHx and NOx in the atmosphere have lead to elevated deposition of biological active $\mathrm{N}$ forms, mostly as $\mathrm{NH}_{4}{ }^{+}$and $\mathrm{NO}_{3}{ }^{-}$on forests in industrialized and densely populated regions. In contrast to former times the percentage of NHx from the nitrogen deposited has been increased drastically and risen in Mid Europe to about 50 \%. The total inorganic $\mathrm{N}$ deposition to the forests for example in Europe ranges from 5 to $80 \mathrm{~kg} \mathrm{~N} \mathrm{ha}^{-1} \mathrm{yr}^{-1}$ and exceeds in most of the cases the amounts of $\mathrm{N}$ immobilized in the annual growth increment of the trees which accounted for generally 5 to $20 \mathrm{~kg} \mathrm{~N} \mathrm{ha}^{-1} \mathrm{yr}^{-1}$. One key question in forest research is:

What is the fate of surplus $\mathrm{N}$ in the forest ecosystems and how do the nitrogen forms and the forest management influence the system internal status and processes with respect to the added nitrogen. There are a large number of experiments and surveys in the last two decades, which recover different aspects of the nitrogen cycle and the biochemical processes involved. Summarising the results one can draw the following image of the effects of $\mathrm{N}$ additions on ecosystem status and the processes with increasing $\mathrm{N}$ deposition: the net $\mathrm{N}$-mineralization, (NNM) net primary production (NPP) and the foliar nitrogen of the trees increase until a maximum reached and then slowly decrease for some reasons. At the stage of maximal Nmineralization the nitrification rates, the nitrogen leaching and the gaseous losses of $\mathrm{N}$ start to increase. Over the whole range of $\mathrm{N}$ deposition there is a trend of decreasing $\mathrm{C} / \mathrm{N}$ ratios of the soil organic matter. These trends appear consistently across the sites studied, however the reactions of the systems differed significantly. Two summary statements can be deduced from the findings. i) In general broad-leaved deciduous species with lower $\mathrm{N}$ use efficiencies and higher $\mathrm{N}$ uptake requirement are more resistant to $\mathrm{N}$ additions than needle-leaved ever green 
species with high $\mathrm{N}$ use efficiencies. ii) The initial $\mathrm{N}$-status is the result of the previous land use and disturbances. The governing factors and processes behind these patterns are still not good understood as well as the prognosis and quantification of the processes induced by $\mathrm{N}$ deposition. Still, open questions are how the previous land use and forest management influenced the initial status of the forest floors and acid soils and how these initial status modifies the processes of N-transformations. Not solved is the question to what extent the presence of tree roots and their mycorrhiza have an impact on the transformation of added nitrogen. Also of interest is the different behaviour of ammonium and nitrate added to the forest floors. Here the question arise whether the N-immobilization is biotic or abiotic in nature. In the Solling forests, located in the southern part of Lower Saxony, the nitrogen depositions amount to an average of $20-40 \mathrm{~kg} \mathrm{~N}^{-1} \mathrm{yr}^{-1}$. While the deciduous forests exhibit the lower and the ever green coniferous forests the higher values of $\mathrm{N}$ deposition, the input of $\mathrm{NH}_{4}{ }^{+}-\mathrm{N}$ and $\mathrm{NO}_{3}{ }^{-}-\mathrm{N}$ is roughly leveled out.

The aim of the present study was to investigate the effects of surplus addition of $\mathrm{N}$ on the forest floors of beech, spruce and mixed species stands in 120 years old forests at Solling. It was hypothesized:

- that the forest floors of spruce stands show a higher degree of N-saturation with increased $\mathrm{N}$-mineralization and losses via nitrate leaching and $\mathrm{N}_{2} \mathrm{O} / \mathrm{NO}$ emissions.

- that atmospheric $\mathrm{N}$ deposition in forest floors increases the net $\mathrm{N}$-mineralization and $\mathrm{N}_{2} \mathrm{O}$ losses at elevated temperatures indicated by higher $Q_{10}$ values for $\mathrm{NNM}$ and $\mathrm{N}_{2} \mathrm{O}$ emissions.

- based on the hypothesis of Aber (1998), mycorrhizal fine roots improve the Nimmobilization without increased $\mathrm{CO}_{2}$ emissions.

- that the applied nitrogen in plant available forms to a lower extent is taken up directly by the plants leading to an immobilization via the litter and forest floor $\mathrm{O}_{\mathrm{F}}+\mathrm{O}_{\mathrm{H}}$.

- that Ammonium is preferred by microorganisms in contrast to plants, resulted in higher total retention when this $\mathrm{N}$-form is applied.

To falsify these hypotheses, a green house study was set up. Incubations of undisturbed coresof the forest floors from old growth beech, spruce and mixed beech-spruce stands were performed, looking for the fate of ${ }^{15} \mathrm{~N}$-labelled ammonium and nitrate fertilizers in the systems with and without plants. Further, incubation studies were carried out to investigate the influence of different silvicultural and deposition history on net C-mineralization, $\mathrm{N}_{2} \mathrm{O}$ emissions as well as net $\mathrm{N}$-mineralization and microbial biomasses. The results presented here 
were compiled in the form of four manuscripts which have the following titles and will be submitted for publication soon.

i) Temperature dependence of C-mineralization and $\mathrm{N}_{2} \mathrm{O}$ emissions in the forest floor of temperate forest ecosystems.

ii) Nitrogen mineralization in $\mathrm{O}_{\mathrm{H}}$ horisons of beech, spruce and mixed species stands affected by temperature and soil microbial status.

iii) Carbon and nutrient status of beech seedlings grown on forest floors treated by labelled $\mathrm{N}$.

iv) Nitrogen transformation in bare and beech covered forest floors. 


\section{Temperature dependence of net $\mathrm{C}$-mineralization and $\mathrm{N}_{2} \mathrm{O}$ emissions from the forest floors of a temperate forest ecosystem}

\subsection{Introduction}

Forest floor is an important link in the biogeochemical cycle of nutrients in forest ecosystems and essential for the nutritional status of forest stands. The nutritional status of the foliage and thereby also the litter is, to some extent, influenced by soil properties (Fernandez and Struchtemeyer, 1984; Liu and Trueby, 1989). The forest floor also is of particular importance for the cycling of nutrients, both because huge amounts of nutrients may be trapped in the organic molecules and also because the mineralization of the organic matter is a rate-limiting process in the nutrient cycle of forest ecosystems. The mechanisms by which tree species influence forest floor acidity, base cations and heavy metal elements are several fold and include interspecific differences in the uptake of cations and anions (Alban, 1982), nitrogen fixation, and ensuing nitrification (Van Miegroet and Cole, 1984), and the stimulation of mineral weathering (Tice et al., 1996). Soil properties can affect forest floor decomposition rates through influencing (i) initial litter quality, notably the concentration of nutrients (Lukumbuzya et al., 1994; Norden, 1994) and recalcitrant organic compounds like lignin and tannins (Flanagan and van Cleve, 1983; Sanger et al., 1996), and (ii) the microenvironment in which litter decomposition takes place, including the communities of soil fauna and microorganisms. Tree species differ in their effect on soil development and nutrient cycling in the forest ecosystem. Tree species may differ also in their short-term (decades) influence on the biological activity and the nutrient availability of soil (e.g. Binkley and Valentine, 1991; Brown, 1992; Gower and Son, 1992). Differences between species in their effect on soil properties are most often explained by differences in the quantity and quality of the above ground litter produced. However, the abundance and composition of soil organisms may also influence the rate of decomposition and subsequently the release of mineral nutrients (e.g. Anderson 1988). Norway spruce and beech are the most widespread conifer and deciduous tree species in central Europe. Important differences between these species occur in their effects on soil and soil solution properties. Differences in rooting patterns lead to different soil exploitation among species, reflect the annual rate of base cations incorporation into the above ground foliar litter. The base-pump effect of beech trees by enlarging the soil volume exploited by the roots, is a basic means by which forest stands incorporate soil mineral nutrients in the living biomass by employment of nutrients from the mineral soil. Norway 
spruce is commonly described as a tree with a flat root system and restricted root development with a much lower penetration energy than most deciduous trees (Rottmann, 1989; Korotaev, 1992). Spruce in the mixed stands may occupy a larger soil volume than in a monoculture, which provides greater possibilities for nutrient acquisition. In addition, the deep-rooted beech in mixed stands may also be able to access nutrients below the rooting zone of spruce, affecting the nutrient storage and turnover of the whole soil profile. Still, there are a few studies in which a variety of coniferous and deciduous tree species growing under similar environmental conditions.

Soil temperature and moisture explain most of the variation in forest floor respiration but additional factors such as forest type, soil nutrient content and texture can be also important for site variation in forest floor respiration. For instance, it is well known that tree species and nutrient availability strongly affect the decomposition of litter, hence, tree species and soil specific factors could influence forest floor respiration. Elevated temperatures are expected to increase the emission of trace gases (e.g. Houghton et al., 1990) and may provide a positive feed back in the global $\mathrm{C}$ cycle due to decreases in soil $\mathrm{C}$ stocks. It has been hypothesised that increased $\mathrm{CO}_{2}$ concentrations in the atmosphere may increase global temperature, which stimulate the flux of carbon dioxide from soils causing a positive feed back effect on the atmospheric $\mathrm{CO}_{2}$ (Jenkinson et al., 1991; Schimel et al., 1994; Kirschbaum, 1995). Nitrous oxide $\left(\mathrm{N}_{2} \mathrm{O}\right)$ is an atmospheric trace gas which plays an important role both in atmospheric chemistry as well as in global warming (e.g. Ramanathan et al., 1985; Cicerone, 1987). As the biogeochemical cycling of nitrogen in soils depends strongly on temperature and precipitation, the potential increase in $\mathrm{N}_{2} \mathrm{O}$ release from the forest floor caused by elevated temperatures may have a positive feed back effect on the atmospheric $\mathrm{N}_{2} \mathrm{O}$ as a result of depletion of higher nitrous oxide emissions.

The objective of this study was to investigate the impacts of tree species in mono and mixed cultures as the source of the litter quality on nutrient stocks of the forest floors and quantification and statistical analyzes of the dynamics of net C-mineralization and $\mathrm{N}_{2} \mathrm{O}$ emission rates affected by temperature increase from undisturbed different forest floors. 


\subsection{Materials and Methods}

\subsubsection{Study site}

The Study site is located at the Solling forest about 70 to $80 \mathrm{~km}$ southward Hannover, Lower Saxony, Germany $\left(51^{\circ} 47^{\prime} \mathrm{N}\right.$ and $\left.9^{\circ} 37^{\prime} \mathrm{E}\right)$ on slightly inclined $\left(2-4^{\circ}\right)$ slopes. The area is situated at $500 \mathrm{~m}$ elevation a.s.1. with a mean annual air temperature of $6.5^{\circ} \mathrm{C}$ and an annual precipitation of $1050 \mathrm{~mm}$. The temperatures range from an average of $14^{\circ} \mathrm{C}$ in July to $-2^{\circ} \mathrm{C}$ in January. The dominant soil type are podsolic, slightly pseudogleyic Dystric Cambisol (FAO) developed on triassic sandstone covered by a layer of loess with a thickness varying from 0.2 to $2 \mathrm{~m}$ (average $80 \mathrm{~cm}$ ). Soil texture is dominated by silty loam. Morphological humus forms are typical moder. Three adjacent stands (area of each $\approx 400 \mathrm{~m}^{2}$ ) were chosen for the study: a mature (100-120 years) Norway spruce (Picea abies L.karst.) stand partly covered by grass, a 100-120-yr-old beech (Fagus sylvatica L.) stand and a mixed spruce-beech stand covered by 100 to 120 years old trees. A surface application of $2.3 \mathrm{t}$ dolomite $\mathrm{ha}^{-1}$ to Norway spruce stand was registered at 1989.

\subsubsection{Soil sampling and experimental design}

Undisturbed forest floor samples were taken in November $2001(n=30)$ from each stand by using a stainless steal auger, placed into an incubation vessel $(8,4 \mathrm{~cm}$ diameter, $14 \mathrm{~cm}$ height). Twelve extra soil cores were collected from each stand to investigate the chemical properties at the beginning of study. Soil cores were sampled randomly and were stored at $4{ }^{\circ} \mathrm{C}$ for a few days until incubation. Samples were incubated at $1,5,10,15$, and $20^{\circ} \mathrm{C}$ with six replications from each stand at each temperature for three months. The moisture content was adjusted weekly with distilled water to maintain the initial water content.

\subsubsection{Soil chemical analyses and calculations}

$\mathrm{CO}_{2}$ and $\mathrm{N}_{2} \mathrm{O}$ emissions from the soil cores were measured once every two weeks throughout the incubation in airtight vessels. $\mathrm{CO}_{2}$ and $\mathrm{N}_{2} \mathrm{O}$ fluxes were determined by means of headspace enrichment at 0,10 , and 20 minutes. Gas samples were analyzed by injection of gas sample into the port of a gas chromatograph (GC 14 A, Shimadzu, Duisburg, Germany) equipped with two detectors, a flame ionization detector (FID), and an electron capture 
detector (ECD), (Loftfield et al. 1997). The $\mathrm{CO}_{2}$ and $\mathrm{N}_{2} \mathrm{O}$ emissions were calculated using linear regression of the change in gas concentrations, based on the following equation:

$F=k \mathrm{CO} 2$ or $k \mathrm{~N} 2 \mathrm{O} \frac{273}{T} \frac{P}{101} \frac{V}{A} \frac{\Delta C}{\Delta t}$

$F$ is the flux rate of $\mathrm{CO}_{2}\left(\mathrm{mg} \mathrm{CO}_{2}-\mathrm{C} \mathrm{m}^{-2} \mathrm{~h}^{-1}\right)$ or $\mathrm{N}_{2} \mathrm{O}\left(\mu \mathrm{g} \mathrm{N} \mathrm{N}_{2} \mathrm{O}-\mathrm{N} \mathrm{m}^{-2} \mathrm{~h}^{-1}\right), k_{\mathrm{CO} 2}\left(0.536 \mu \mathrm{g} \mathrm{C} \mu \mathrm{l}^{-}\right.$ $\left.{ }^{1}\right), k_{\mathrm{N} 2 \mathrm{O}}\left(1.25 \mu \mathrm{g} \mathrm{N} \mathrm{l}^{-1}\right)$ are unit conversion factors for calculating $\mathrm{CO}_{2}$ and $\mathrm{N}_{2} \mathrm{O}$ flux rates, $T$ is the air temperature $\left({ }^{\circ} \mathrm{K}\right), \mathrm{P}$ is the atmospheric pressure $(\mathrm{k} \mathrm{Pa}), V$ is the air volume of the headspace gas above the samples (L), $A$ is the area of humus samples $\left(\mathrm{m}^{2}\right)$ and $\Delta C / \Delta t$ is the rate of change in concentration of $\mathrm{CO}_{2}$ and $\mathrm{N}_{2} \mathrm{O}$, within the headspace $\left(\mu \mathrm{l}^{-1} \mathrm{~h}^{-1}\right)$.

Exponential function equation (2) was used to calculate the temperature effects on soil $\mathrm{CO}_{2}$ and $\mathrm{N}_{2} \mathrm{O}$ fluxes by a fitting procedure, where the parameters $b_{0}$ and $b_{1}$ were calculated.

Flux $=b_{0} \cdot e^{(b 1 . T)}$

"Flux" is the measured $\mathrm{CO}_{2}$ or $\mathrm{N}_{2} \mathrm{O}$ emissions and $T$ is the soil temperature. The $Q_{10}$ function (3) was used to show temperature sensitivities of a complex of biochemical processes in soil, calculated as:

$Q_{10}=e^{(10 b 1)}$

The total $\mathrm{C}$ and $\mathrm{N}$ content of the forest floor were analysed by dry combustion with a $\mathrm{CN}$ auto analyser (Vario, Elementar Analysensysteme, Hanau, Germany). The elements P, S, Na, $\mathrm{K}, \mathrm{Ca}, \mathrm{Mg}, \mathrm{Mn}, \mathrm{Fe}$ and $\mathrm{Al}$ in the humus samples were analysed by ICP-AES (Spectro Analytical Instruments, Kleve, Germany) after pressure digestion in $65 \%$ concentrated $\mathrm{HNO}_{3}$. Soil $\mathrm{pH}$ was measured with a digital $\mathrm{pH}$-meter (WTW GmbH Wesl-Germany) in water and 1 mol $1^{-1} \mathrm{KCl}$.

Analysis of variance (ANOVA) were tested by Mann-Whitney U-Test at $\mathrm{P}<0.05$ level, performed by the program Statistica version 6.0. 


\subsection{Results and Discussion}

\subsubsection{Impact of site on forest floors properties}

The thickness and the chemical characteristics of the forest floors were found very similar and statistically not significantly different $(p<0.05)$ between the stands (Table 1). All forest floors were acidic with $\mathrm{pH}_{\left(\mathrm{H}_{2} \mathrm{O}\right)}$ ranging from 3.58 at beech stand followed by $3.96-3.64$ at spruce and mixed species stands. The concentration of organic carbon ranged from $379 \mathrm{~g} \mathrm{~kg}^{-1}$ at beech to $378-359 \mathrm{~g} \mathrm{~kg}^{-1}$ at spruce and mixed species forest floors. The total nitrogen concentration varied between $18.1 \mathrm{~g} \mathrm{~kg}^{-1}$ at beech stand and $16.1-15.6 \mathrm{~g} \mathrm{~kg}^{-1}$ at mixed and spruce stands, resulting in a variation of the C:N ratio from 24.2 at spruce to $22.4-20.9$ at mixed and beech forest floors. In comparison to beech stand the $\mathrm{C}: \mathrm{N}$ ratios at spruce and mixed forest floors indicated slightly higher accumulation rates for $\mathrm{C}$ than for $\mathrm{N}$. The narrower $\mathrm{C}: \mathrm{N}$ ratio at beech stand may originate from more $\mathrm{N}$ deposition at the beech forest floor by N-enriched litter (9.91 vs. $7.70 \mathrm{mg} \mathrm{g}^{-1}$ ) and excess of litter accumulation (3.72 vs. $3.22 \mathrm{t} \mathrm{ha}^{-1} \mathrm{a}^{-1}$ ) in compare to spruce stand (Table 3 ). The present results suggest that the feed backs between long-term elevated $\mathrm{N}$ deposition and $\mathrm{C}$ turnover in forest floors have important implications for the sequestration of $\mathrm{C}$ in the studied forest soils. The Phosphorous concentration at beech stand amounted to $0.96 \mathrm{~g} \mathrm{~kg}^{-1}$, while at mixed and spruce stands accounted for $0.86-0.81 \mathrm{~g} \mathrm{~kg}^{-1}$ resulting in a variation of the C:P ratio from 467 at spruce to $417-395$ at mixed and beech forest floors. The non significant differences in P concentration of the forest floors resulted in a characteristic converging trend in $\mathrm{C}: \mathrm{P}$ ratios for beech, spruce and mixed species stands. Ratios of C:P mineralization were 18.6 - 19.3 times greater than $\mathrm{C}: \mathrm{N}$ mineralization ratios, typically by an order of magnitude. This is in consistent with other studies showing that microorganisms can immobilize or release almost all available phosphate in organic matter (e.g., Walbridge and Vitousek, 1987). The mean concentrations of the base cations $\mathrm{Na}, \mathrm{K}, \mathrm{Ca}, \mathrm{Mg}$ as well as $\mathrm{Fe}$ and $\mathrm{Al}$ and anions $\mathrm{S}$ and $\mathrm{Mn}$ in the forest floors were also very similar and insignificantly different (Table 2). The insignificant variation in base and heavy metal cations as well as phosphorous and sulphur concentrations between the forest floors appeared to reflect the same composition of the parent material of the three adjacent stands under mono and mixed species trees. Similar acidity and base cations concentrations of deciduous beech forest floor in compare to coniferous spruce and mixed species stands demonstrated that the base-pump effect of beech did not greatly influence on the nutritional status at the beech stand. The comparable similar values of the base cations in spruce stand 
with beech and mixed species stands might be to some extent in relation to surface additions of lime on the forest floor of spruce at 1989. The fact that acidifying effects of pure spruce are hardly visible at low $\mathrm{pH}$ is not only the consequence of the liming, but also the consequence of general low base content of the foliage litter, which does not allow sequestration of large amounts of base cations in the forest floor lowering forest floor $\mathrm{pH}$. The rates of litter decomposition and nutrient release from litter depends in large part on the direct effects of litter quality (McClaugherty et al., 1985; Scott and Binkley, 1997; Ferrari, 1999). Litter nitrogen concentration is of special importance for decomposition, because it determines the growth and turnover of microbial biomass (Heal et al.,1997), as well as litter consumption rates by soil organisms and their interactions (Herlitzius, 1983; Wardle and Lavelle, 1997). Lignin concentration and the ratios of lignin: $\mathrm{N}$ and $\mathrm{C}: \mathrm{N}$ of litter claimed to be the key factors to estimate the litter quality are also believed to control the rate of litter decomposition (Meentemeyer, 1978; Melillo et al., 1982; McClaugherty and Berg, 1987; Taylor et al., 1989; Aber et al., 1990; Scott and Binkley, 1997). Comparing the concentrations of N, lignin and the ratios of lignin to $\mathrm{N}$ in foliar litter of beech and spruce revealed similar substrate quality of beech and spruce stands (Table 3) (Ellenberg et al., 1986; Berg and Meentemeyer, 2002). This suggests that the forest floors at the study area offer similar conditions for litter decomposer organisms and that the trees in mono and mixed species cultures may have implications for soil development due to similarity in nutrient status and acidity. Khanna and Ulrich, (1991) argued that, the average concentration of most elements in each component of the vegetation usually varies little between species for a given site when compared with the variation in concentration of elements among different sites. The results of the present study testified the assumption that tree species in mono and mixed cultures would not significantly affect nutrient input (deposition), but that nutrient distribution within the stands would differ, due to different rates of biomass production (litter fall) and nutrient efficiencies. The time delay between litter input and decomposition results in sequestration of $\mathrm{C}$ and $\mathrm{N}$ in soils, and the amount of $\mathrm{C}$ and $\mathrm{N}$ stored or mineralized mainly depends on the ratio between input of organic matter to forest floor by litter fall and decomposition by a range of microbes. In fact, the rate of nutrient deposition and the release of nutrients is site specific and mainly influenced by the soil type. 
Table 1. Mean forest floor characteristics at each stand $(n=30)$ including the $\mathrm{pH}$, total concentrations of carbon and nitrogen, $\mathrm{C}: \mathrm{N}$ and $\mathrm{C}: \mathrm{P}$ ratios, (Standard deviation represent in parentheses).

\begin{tabular}{|c|c|c|c|c|c|c|c|c|c|}
\hline \multirow[t]{2}{*}{ stand } & \multirow{2}{*}{$\begin{array}{l}\text { depth } \\
(\mathrm{cm})\end{array}$} & \multirow{2}{*}{$\begin{array}{c}\text { mass } \\
\left(\mathrm{Mg} \mathrm{ha}^{-1}\right)\end{array}$} & \multirow{2}{*}{$\begin{array}{c}\text { moisture } \\
(\%)\end{array}$} & \multicolumn{2}{|c|}{$\mathrm{pH}$} & $\mathrm{C}_{\text {org }}$ & $\mathrm{N}_{\mathrm{t}}$ & \multirow[t]{2}{*}{$\mathrm{C} / \mathrm{N}$} & \multirow[t]{2}{*}{$\mathrm{C} / \mathrm{P}$} \\
\hline & & & & $\overline{(\mathrm{KCl})}$ & $\left(\mathrm{H}_{2} \mathrm{O}\right)$ & \multicolumn{2}{|c|}{$\left(\mathrm{g} \mathrm{kg}^{-1}\right)$} & & \\
\hline beech & 5.03 & $\begin{array}{c}49.0 \\
(10.7)\end{array}$ & $\begin{array}{c}59.5 \\
(2.42)\end{array}$ & $\begin{array}{l}2.76 \\
(0.07)\end{array}$ & $\begin{array}{c}3.58 \\
(0.13)\end{array}$ & $\begin{array}{c}379 \\
(58.7)\end{array}$ & $\begin{array}{c}18.1 \\
(2.85)\end{array}$ & $\begin{array}{c}20.9 \\
(1.69)\end{array}$ & $\begin{array}{c}395 \\
(23.0)\end{array}$ \\
\hline spruce & 5.77 & $\begin{array}{c}57.5 \\
(21.4)\end{array}$ & $\begin{array}{c}61.0 \\
(8.74)\end{array}$ & $\begin{array}{l}3.30 \\
(0.58)\end{array}$ & $\begin{array}{c}3.96 \\
(0.50)\end{array}$ & $\begin{array}{c}378 \\
(58.3)\end{array}$ & $\begin{array}{c}15.6 \\
(2.68)\end{array}$ & $\begin{array}{c}24.2 \\
(1.95)\end{array}$ & $\begin{array}{c}467 \\
(36.2)\end{array}$ \\
\hline mixed & 5.41 & $\begin{array}{c}53.2 \\
(18.4)\end{array}$ & $\begin{array}{c}59.4 \\
(9.41)\end{array}$ & $\begin{array}{l}2.82 \\
(0.11)\end{array}$ & $\begin{array}{c}3.64 \\
(0.12)\end{array}$ & $\begin{array}{c}359 \\
(84.8)\end{array}$ & $\begin{array}{c}16.1 \\
(3.51)\end{array}$ & $\begin{array}{c}22.4 \\
(2.40)\end{array}$ & $\begin{array}{c}417 \\
(26.2)\end{array}$ \\
\hline
\end{tabular}

Table 2. Mean element concentration of the forest floors of beech, spruce and mixed species stands, analyzed by the $\mathrm{HNO}_{3}$ pressure digestion method (Standard deviation represent in parentheses).

\begin{tabular}{|c|c|c|c|c|c|c|c|c|c|}
\hline stand & $\mathrm{P}$ & S & $\mathrm{Na}$ & $\mathrm{K}$ & $\mathrm{Ca}$ & $\mathrm{Mg}$ & $\mathrm{Mn}$ & $\mathrm{Fe}$ & $\mathrm{Al}$ \\
\hline beech & $\begin{array}{c}0.96 \\
(0.17)\end{array}$ & $\begin{array}{c}1.98 \\
(0.53)\end{array}$ & $\begin{array}{c}0.23 \\
(0.07)\end{array}$ & $\begin{array}{c}2.87 \\
(1.21)\end{array}$ & $\begin{array}{c}5.53 \\
(3.31)\end{array}$ & $\begin{array}{c}1.52 \\
(0.75)\end{array}$ & $\begin{array}{c}0.61 \\
(0.40)\end{array}$ & $\begin{array}{c}7.97 \\
(3.35)\end{array}$ & $\begin{array}{c}12.2 \\
(5.97)\end{array}$ \\
\hline spruce & $\begin{array}{c}0.81 \\
(0.10)\end{array}$ & $\begin{array}{c}1.84 \\
(0.24)\end{array}$ & $\begin{array}{c}0.20 \\
(0.03)\end{array}$ & $\begin{array}{c}2.08 \\
(0.64)\end{array}$ & $\begin{array}{c}4.28 \\
(1.06)\end{array}$ & $\begin{array}{c}1.35 \\
(0.34)\end{array}$ & $\begin{array}{c}0.65 \\
(0.41)\end{array}$ & $\begin{array}{c}6.78 \\
(1.41)\end{array}$ & $\begin{array}{c}8.23 \\
(2.55)\end{array}$ \\
\hline mixed & $\begin{array}{c}0.86 \\
(0.10)\end{array}$ & $\begin{array}{c}1.58 \\
(0.37)\end{array}$ & $\begin{array}{c}0.24 \\
(0.04)\end{array}$ & $\begin{array}{c}2.87 \\
(0.90)\end{array}$ & $\begin{array}{c}2.99 \\
(1.04)\end{array}$ & $\begin{array}{c}1.16 \\
(0.26)\end{array}$ & $\begin{array}{c}0.31 \\
(0.28)\end{array}$ & $\begin{array}{c}9.04 \\
(2.67)\end{array}$ & $\begin{array}{c}12.1 \\
(4.10)\end{array}$ \\
\hline
\end{tabular}

Table 3. Mean annual litterfall in $\mathrm{t} / \mathrm{ha} / \mathrm{yr}\left(100^{\circ} \mathrm{C} \mathrm{DW}\right)$ at Solling forest and the concentrations of $\mathrm{N}$, lignin and lignin: $\mathrm{N}$ ratio in foliar litter of beech and Norway spruce in Europe. The range in values are given in parentheses.

\begin{tabular}{ccccc}
\hline Litter type & Litterfall & $\mathrm{N}$ & Lignin & Lignin: N \\
\cline { 3 - 4 } & & \multicolumn{2}{c}{$\left(\mathrm{mg} \mathrm{g}^{-1}\right)$} & \\
\hline Common beech & 3.72 & 9.91 & 393 & 39.7 \\
& $(3.14-4.53)$ & $(5.6-16.8)$ & $(284-513)$ & \\
Norway spruce & 3.22 & 7.70 & 317 & 41.2 \\
& $(2.01-4.96)$ & $(4.5-14.2)$ & $(277-350)$ & \\
\hline
\end{tabular}




\subsubsection{Temperature dependence of net $\mathrm{C}$ mineralization}

The rates of net $\mathrm{C}$ mineralization increased exponentially $\left(R^{2}=0.92-0.99\right)$ with increase of temperature during 12 weeks incubation period at the three stands (Figure1). The C mineralization at spruce stand was slightly higher than the fluxes of $\mathrm{C}$ mineralized at beech and mixed species forests, however except lower temperatures not significantly different as related to the measured units (Table 4). In order to characterize site differences while holding a temperature constant, forest floor respiration rates at $6.5^{\circ} \mathrm{C}$ as mean annual air temperature at the study area were predicted by using the exponential function, revealed no significant effect of site on net $\mathrm{C}$ mineralization between the stands (Table 3). With the same nutrient concentrations of biomass, beech and spruce in mono and mixed cultures indicated the same biomass production and intensity of biomass removal reflected in the rates of net $\mathrm{C}$ mineralization. The effect of beech-spruce mixed stand on carbon losses indicated that $\mathrm{CO}_{2}$ release of the forest floor at mixed species stand ranging from pure beech to pure spruce. As a result of the prevailing insignificant differences between the stands the mean net $\mathrm{C}$ mineralization along the temperature increase is calculated and shown in figure 4(a). To indicate the temperature dependence of forest floor $\mathrm{C}$ mineralization an exponential regression equation model has been used along the temperature increase, ranged from 1 to $20^{\circ} \mathrm{C}$ for all three stands. All forest floors exhibited an exponential increase in $\mathrm{CO}_{2}$ efflux with respect to temperature increase. The temperature sensitivities of the forest floors $\left(Q_{10}\right.$ values) ranged from 1.64 to 2.26 dependent on the measured units between the stands (Table 3 ). The calculated $Q_{10}$ values, as the index of the mean temperature sensitivity of the three stands amounted to an average of $1.73-2.10$ per measured units (Table 5). Lioyd and Taylor (1994) argued that over a wider temperature range microbial populations responsible for soil organic matter decomposition might change, hence, $Q_{10}$ values, the indicator of temperature sensitivity, may alter due to change in biochemical reactions of microbes to temperature variations. However, their temperature range was about twice the range found in this study. In comparison, the relatively small temperature range in this experiment might be responsible for high correlation coefficient $\left(R^{2}=0.92-0.99\right)$. The similar $Q_{10}$ values between the stands suggest that the relative activities of decomposers might be influenced more by abiotic factors such as temperature than biotic factors such as microbial species and substrate quality. The temperature dependency of net $\mathrm{C}$ mineralization in this study is consistent with results from other laboratory incubations studies in temperate forests. For example, experiments with litter (e.g. Kirschbaum, 1995) and soil organic matter (e.g. Kaetterer et al., 1998) indicated a 
strong temperature dependency of carbon mineralization rate. In addition in models used to estimate the consequences of the global warming on trace gases evolutions such a dependence has been a pivotal element (e.g.Houghton et al., 1998; Kirschbaum, 2000; Schlesinger and Andrews, 2000). The percentage of initial $\mathrm{C}$ mineralized during the incubation time at $20^{\circ} \mathrm{C}$ declined in all forest floors with a much higher decrease at the spruce forest floor as compared to the beech and mixed species stands (Figure 2). This suggests that at the beginning of incubation the easily decomposable fraction of organic matter will be mineralized more quickly than the later stages of incubation time when the light fraction is nearly mineralized and respiration rates are nearly constant (c.f. Kirschbaum, 1995). This implies that in the last stages of incubation there will be less easily decomposable matter left over than at the begin of incubation and the rates of these changes are slower at beech and mixed species forest floors compared to spruce stand. Kirschbaum, (1995) argued that as a result of the changing amount of decomposable matter along the incubation time, at the late stages of incubation inhibiting metabolites may have been accumulated, resulted in adulterate the temperature dependence of $\mathrm{C}$ mineralization which caused lower values of respiration rates, while at the beginning of incubation the composition of the samples are sill unaltered and the evolution rates are high due to microbial stimulation by disturbances.

Table 3. Parameters of the $Q_{10}$ regressions $\left(F l u x=b_{0} . e^{(b 1 . T)}\right)$ fitted on the average soil respiration data, $Q_{10}$ values and the calculated flux at the mean annual air temperature at Solling area.

\begin{tabular}{ccccccc}
\hline Flux & stand & $b_{0}$ & $b_{1}$ & $R^{2}$ & $Q_{10}$ & $\begin{array}{c}\mathrm{CO}_{2}-\mathrm{C} \text { flux } \\
\text { at } 6.5^{\circ} \mathrm{C}\end{array}$ \\
\hline $\begin{array}{c}\text { per unit-area } \\
\left(\mathrm{g} \mathrm{C} \mathrm{m}^{-2} \mathrm{~d}^{-1}\right)\end{array}$ & beech & 0.301 & 0.060 & 0.97 & 1.83 & 0.445 \\
& spruce & 0.422 & 0.055 & 0.99 & 1.73 & 0.601 \\
mixed & 0.323 & 0.050 & 0.95 & 1.64 & 0.447 \\
per unit-mass & beech & 0.061 & 0.066 & 0.95 & 1.94 & 0.094 \\
$\left(\mathrm{~g} \mathrm{C} \mathrm{kg}^{-1} \mathrm{~d}^{-1}\right)$ & spruce & 0.057 & 0.082 & 0.99 & 2.26 & 0.097 \\
& mixed & 0.056 & 0.071 & 0.92 & 2.02 & 0.088 \\
per unit- $_{\text {org }}$ & beech & 0.157 & 0.069 & 0.97 & 1.99 & 0.245 \\
$\left(\mathrm{~g} \mathrm{C} \mathrm{kg} \mathrm{Corg}^{-1} \mathrm{~d}^{-1}\right)$ & spruce & 0.155 & 0.081 & 0.98 & 2.24 & 0.262 \\
& mixed & 0.149 & 0.073 & 0.94 & 2.07 & 0.239 \\
per unit- $_{\mathrm{t}}$ & beech & 3.266 & 0.069 & 0.97 & 1.99 & 5.108 \\
$\left(\mathrm{~g} \mathrm{C} \mathrm{kg} \mathrm{N}_{\mathrm{t}}^{-1} \mathrm{~d}^{-1}\right)$ & spruce & 3.780 & 0.080 & 0.98 & 2.23 & 6.358 \\
& mixed & 3.312 & 0.073 & 0.95 & 2.07 & 5.318 \\
\hline
\end{tabular}


Table 4. Results of statistical tests on the average net C-mineralization at different incubation temperatures between the stands, Mann-Whitney (U-Test) [(*): significant, $0.05>P>0.01)]$.

\begin{tabular}{|c|c|c|c|c|c|c|}
\hline \multirow[t]{2}{*}{ Flux } & \multirow[t]{2}{*}{ stand } & \multicolumn{5}{|c|}{$\mathrm{CO}_{2}$-C flux } \\
\hline & & $1^{\circ} \mathrm{C}$ & $5^{\circ} \mathrm{C}$ & $10^{\circ} \mathrm{C}$ & $15^{\circ} \mathrm{C}$ & $20^{\circ} \mathrm{C}$ \\
\hline \multirow{3}{*}{ per unit-area } & beech/spruce & * & ns & ns & ns & ns \\
\hline & spruce/mixed & $*$ & ns & ns & ns & $*$ \\
\hline & beech $/$ mixed & ns & ns & ns & ns & ns \\
\hline \multirow{3}{*}{ per unit-mass } & beech/spruce & $*$ & $\mathrm{~ns}$ & $\mathrm{~ns}$ & $\mathrm{~ns}$ & ns \\
\hline & spruce/mixed & $*$ & $*$ & ns & ns & ns \\
\hline & beech/mixed & ns & $*$ & ns & ns & ns \\
\hline \multirow[t]{3}{*}{ per unit- $\mathrm{C}_{\text {org }}$} & beech/spruce & ns & ns & ns & ns & ns \\
\hline & spruce/mixed & ns & * & ns & ns & ns \\
\hline & beech $/$ mixed & ns & $*$ & ns & ns & ns \\
\hline \multirow[t]{3}{*}{ per unit- $\mathrm{N}_{\mathrm{t}}$} & beech/spruce & $*$ & ns & ns & ns & ns \\
\hline & spruce/mixed & ns & $*$ & ns & ns & ns \\
\hline & beech/mixed & ns & * & ns & ns & ns \\
\hline
\end{tabular}

Table 5. Parameters of the $Q_{10}$ regressions $\left(F l u x=b_{0} . e^{(b 1 . T)}\right)$ fitted on the average soil respiration data, $Q_{10}$ values and the calculated flux at mean of the three stands by mean annual air temperature at Solling.

\begin{tabular}{cccccc}
\hline Flux & $b_{0}$ & $b_{1}$ & $R^{2}$ & $Q_{10}$ & $\begin{array}{c}\mathrm{CO}_{2}-\mathrm{C} \text { flux } \\
\text { at } 6.5^{\circ} \mathrm{C}\end{array}$ \\
\hline $\begin{array}{c}\text { per unit-area } \\
\left(\mathrm{g} \mathrm{C} \mathrm{m}^{-2} \mathrm{~d}^{-1}\right)\end{array}$ & 0.348 & 0.055 & 0.98 & 1.73 & 0.498 \\
$\begin{array}{c}\text { per unit-mass } \\
\left(\mathrm{g} \mathrm{C} \mathrm{kg} \mathrm{k}^{-1} \mathrm{~d}^{-1}\right)\end{array}$ & 0.058 & 0.073 & 0.99 & 2.07 & 0.093 \\
$\begin{array}{c}\text { per unit- } \mathrm{org} \\
\left(\mathrm{g} \mathrm{C} \mathrm{kg}^{-1} \mathrm{C}_{\text {org }} \mathrm{d}^{-1}\right)\end{array}$ & 0.154 & 0.074 & 0.99 & 2.10 & 0.249 \\
$\begin{array}{c}\text { per unit- } \mathrm{t} \\
\left(\mathrm{mg} \mathrm{N} \mathrm{kg} \mathrm{N}_{\mathrm{t}}^{-1} \mathrm{~d}^{-1}\right)\end{array}$ & 3.460 & 0.074 & 0.99 & 2.10 & 5.606 \\
\hline
\end{tabular}


Figure 1. Net C-mineralization from the forest floor of spruce, beech and mixed species stands related to area (a), dry matter (b), $\mathrm{C}_{\text {org }}(\mathrm{c})$ and $\mathrm{N}_{\text {total }}(\mathrm{d})$ as a function of temperature.

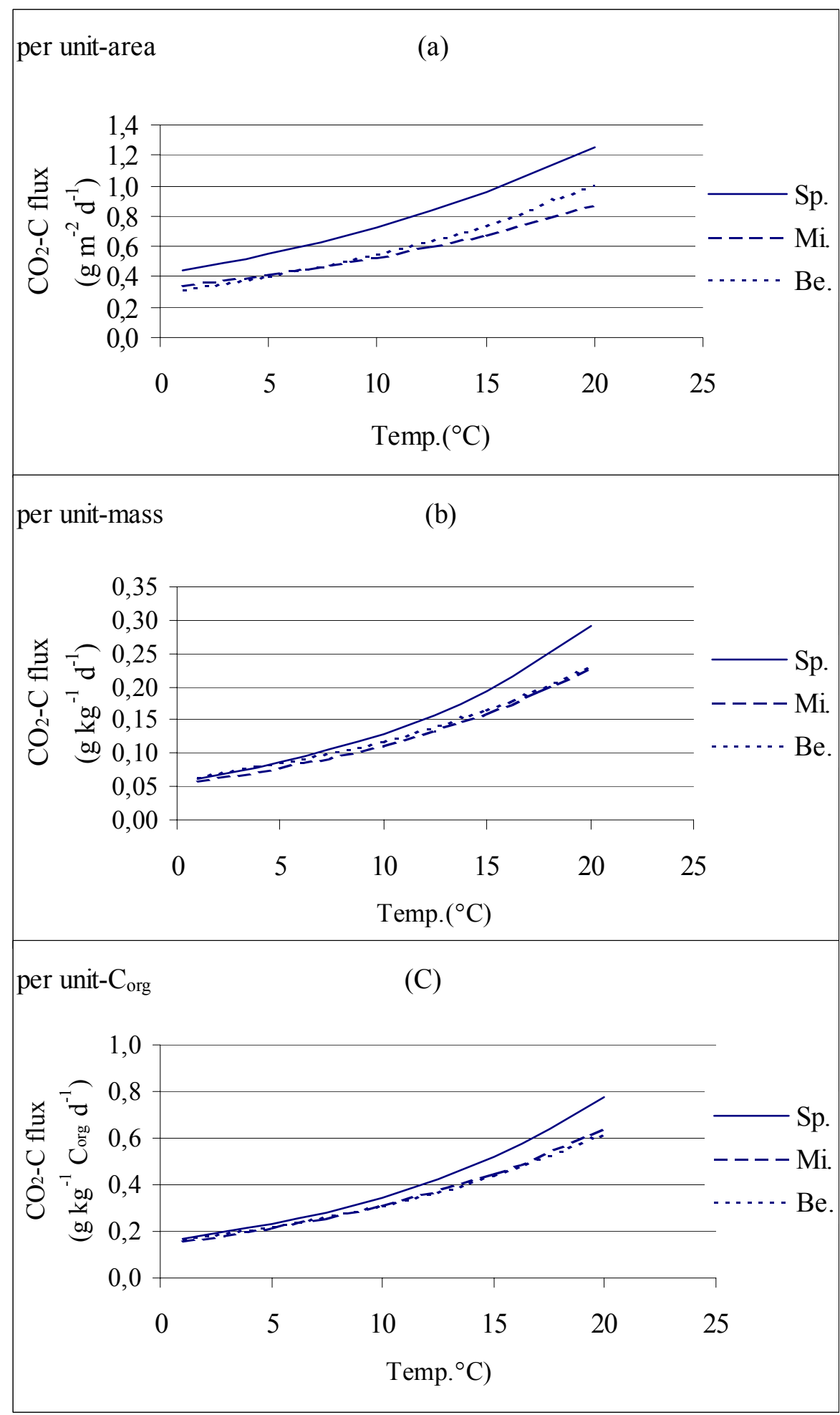




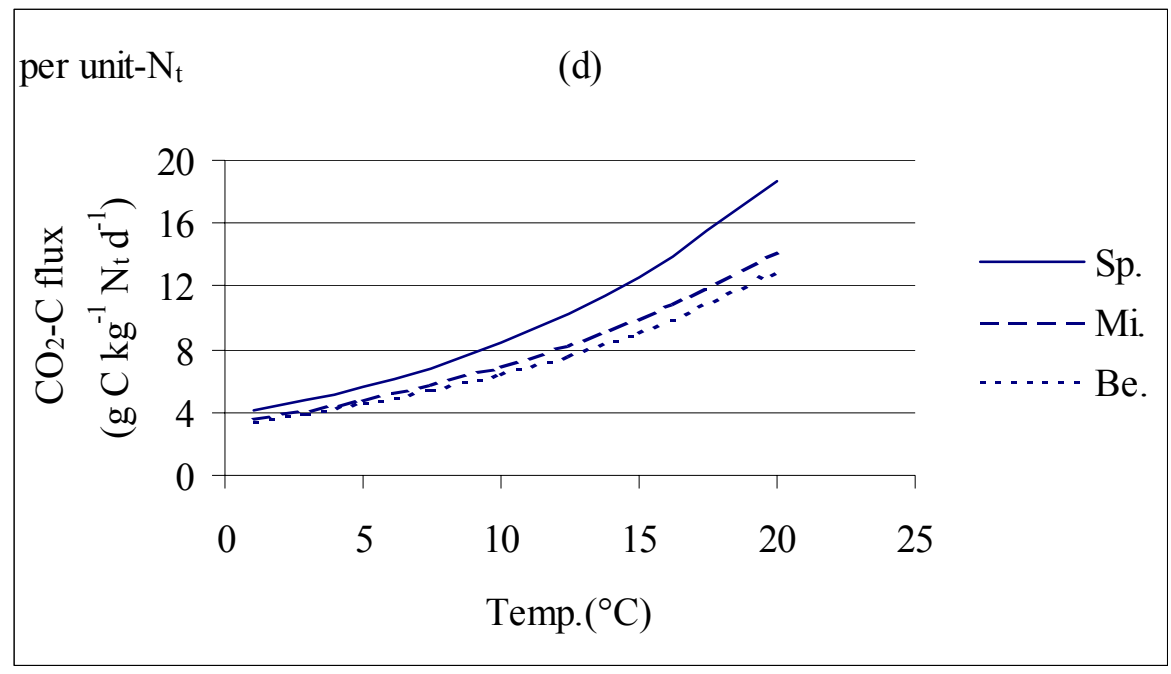

Figure 2. Percentage of initial respiration rates per unit area at $20^{\circ} \mathrm{C}$ over the incubation period.

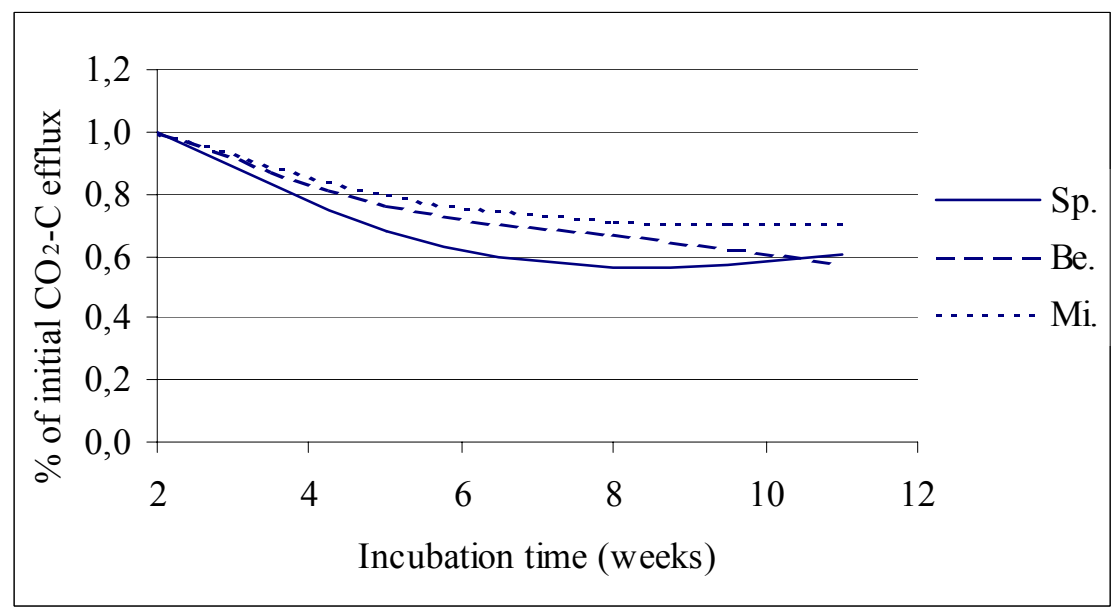

\subsubsection{Temperature dependence of $\mathrm{N}_{2} \mathrm{O}$ emission rates}

The rates of $\mathrm{N}_{2} \mathrm{O}$ efflux over the incubation period increased exponentially with increase of temperature in the range of 1 to $20^{\circ} \mathrm{C}$ at the three stands (Figure 3). A high correlation was found between the flux rates of $\mathrm{N}_{2} \mathrm{O}$ and the elevating incubation temperature $\left(R^{2}=0.97-\right.$ 1.00) (Table 6). The markedly differences in $\mathrm{N}_{2} \mathrm{O}$ production rates between the stands were only detected at lower temperatures, while at elevated temperatures the differences between the stands were disappeared (Table 8). As the general climatic and edaphic conditions for the three adjacent stands are identical, the $\mathrm{N}_{2} \mathrm{O}$ emission rates at mean annual air temperature at the study area $\left(6.5^{\circ} \mathrm{C}\right)$ were calculated for each stand revealed no impact of site on production 
rates of $\mathrm{N}_{2} \mathrm{O}$ (Table 6). The commencement of high $\mathrm{N}_{2} \mathrm{O}$ emissions after $10^{\circ} \mathrm{C}$ was nearly the same on all stands along the gradient, due to a similar increase in soil temperature at the three stands. As a result of the prevailing insignificant differences between the stands the mean $\mathrm{N}_{2} \mathrm{O}$ emission rates along the temperature increase is calculated and shown in figure 4(b). The temperature sensitivity of $\mathrm{N}_{2} \mathrm{O}$ emissions ( $Q_{10}$ values) from the forest floors ranged from 2.38 to 3.84 between the stands dependent on the related units (Table 6). The calculated $Q_{10}$ values, as the index of mean temperature sensitivity of the three stands amounted to an average of 2.81 to 3.58 per measured units (Table 7). Sitaula and Bakken (1993) determined $Q_{10}$ values between 1.2 and 2.7 for $\mathrm{N}_{2} \mathrm{O}$ production for a spruce forest, which are in consistent with the presented results. On the basis of field measurements at a beech site, Brumme (1995) calculated $Q_{10}$ values for different soil water tensions of $0.9-9.8$ in Solling area. The exponential increase in $\mathrm{N}_{2} \mathrm{O}$ emission rates along the temperature increase can be explained by the stimulation of microbial $\mathrm{N}$ turn over rates in the forest floors and an increase of microbial population involved in $\mathrm{N}_{2} \mathrm{O}$ production and emission (Naegele and Conrad, 1990; Papen et al., 1991; Nodar et al., 1992). Therefore the increased availability of $\mathrm{NH}_{4}{ }^{+}$and $\mathrm{NO}_{3}{ }_{3}$ in the forest floors due to general increase in nitrification and denitrification activity of microbes resulting in enhanced $\mathrm{N}_{2} \mathrm{O}$ emissions. According to Robertson (1989) several factors may be responsible for the regulation of denitrification and nitrification besides the stimulating effect of soil temperature on all microorganisms. Because the rate of biological denitrification is primarily dependent on the rates of diffusion versus the consumption of oxygen, the oxygen concentration may be influenced by several synergetic processes if temperature changes occur. The temperature effect may also be higher due to reduced supply of oxygen at higher temperatures. Under laboratory incubation conditions temperature increase will increase microbial oxygen demand and due to higher oxygen consumption and activity of soil microorganisms resulted in increase of anaerobic conditions which may stimulate $\mathrm{N}_{2} \mathrm{O}$ losses by nitrifier nitrification (Groffman, 1991) or denitrification. Moreover, with increasing temperature mineralization and nitrification are stimulated, may result in a higher nitrate concentration, increased the denitrification if nitrate is a limiting factor and may also increase the $\mathrm{N}_{2} \mathrm{O} / \mathrm{N}_{2}$ ratio (Weier et al., 1993). Higher rates of nitrification may also increase the losses if this process is involved in the formation of $\mathrm{N}_{2} \mathrm{O}$. 
Table 6. Parameters of the $Q_{10}$ regressions $\left(F l u x=b_{0} \cdot e^{(b 1 . T)}\right)$ fitted on the average $\mathrm{N}_{2} \mathrm{O}$ emissions data, $Q_{10}$ values and the calculated flux at the mean annual air temperature at Solling.

\begin{tabular}{ccccccc}
\hline Flux & stand & $b_{0}$ & $b_{1}$ & $R^{2}$ & $Q_{10}$ & $\begin{array}{c}\mathrm{N}_{2} \mathrm{O}-\mathrm{N} \text { flux } \\
\text { at } 6.5^{\circ} \mathrm{C}\end{array}$ \\
\hline per unit-area & beech & 0.048 & 0.117 & 0.98 & 3.24 & 0.103 \\
$\left(\mathrm{mg} \mathrm{N} \mathrm{m}^{-2} \mathrm{~d}^{-1}\right)$ & spruce & 0.077 & 0.087 & 0.99 & 2.38 & 0.136 \\
& mixed & 0.032 & 0.109 & 0.98 & 2.99 & 0.066 \\
& & & & & \\
per unit-mass & beech & 0.010 & 0.123 & 0.99 & 3.44 & 0.022 \\
$\left(\mathrm{mg} \mathrm{N} \mathrm{kg}^{-1} \mathrm{~d}^{-1}\right)$ & spruce & 0.007 & 0.135 & 0.97 & 3.84 & 0.016 \\
& mixed & 0.006 & 0.125 & 0.99 & 3.49 & 0.014 \\
per unit- $_{\mathrm{t}}$ & beech & 0.504 & 0.129 & 0.99 & 3.64 & 1.168 \\
$\left(\mathrm{mg} \mathrm{N} \mathrm{kg} \mathrm{N}_{\mathrm{t}}^{-1} \mathrm{~d}^{-1}\right)$ & spruce & 0.546 & 0.122 & 0.98 & 3.39 & 1.207 \\
& mixed & 0.340 & 0.132 & 1.00 & 3.74 & 0.801 \\
\hline
\end{tabular}

Table 7. Parameters of the $Q_{10}$ regressions $\left(F=b_{0} \cdot e^{(b 1 . T)}\right)$ fitted on the average $\mathrm{N}_{2} \mathrm{O}$ emissions data, $Q_{10}$ values and the calculated flux at mean of the three stands by mean annual air temperature at Solling.

\begin{tabular}{cccccc}
\hline Flux & $b_{0}$ & $b_{1}$ & $R^{2}$ & $Q_{10}$ & $\begin{array}{c}\mathrm{N}_{2} \mathrm{O}-\mathrm{N} \text { flux } \\
\text { at } 6.5^{\circ} \mathrm{C}\end{array}$ \\
\hline $\begin{array}{c}\text { per unit-area } \\
\left(\mathrm{mg} \mathrm{N} \mathrm{m}^{-2} \mathrm{~d}^{-1}\right)\end{array}$ & 0.052 & 0.103 & 0.99 & 2.81 & 0.101 \\
$\begin{array}{c}\text { per unit-mass } \\
\left(\mathrm{mg} \mathrm{N} \mathrm{kg}^{-1} \mathrm{~d}^{-1}\right) \\
\text { per unit-N }\end{array}$ & 0.008 & 0.127 & 1.00 & 3.56 & 0.017 \\
$\left(\mathrm{mg} \mathrm{N} \mathrm{kg} \mathrm{N}_{\mathrm{t}}^{-1} \mathrm{~d}^{-1}\right)$ & 0.461 & 0.127 & 0.99 & 3.58 & 1.055 \\
\hline
\end{tabular}


Table 8. Results of statistical tests on the average $\mathrm{N}_{2} \mathrm{O}$ emission rates at different incubation temperatures between the stands, Mann-Whitney (U-Test) [(*): significant, $0.05>P>0.01)]$.

\begin{tabular}{|c|c|c|c|c|c|c|}
\hline \multirow[t]{2}{*}{ Flux } & \multirow[t]{2}{*}{ stand } & & - & \multicolumn{3}{|l|}{$\mathrm{N}_{2} \mathrm{O}-\mathrm{N}$ flux } \\
\hline & & $1^{\circ} \mathrm{C}$ & $5^{\circ} \mathrm{C}$ & $10^{\circ} \mathrm{C}$ & $15^{\circ} \mathrm{C}$ & $20^{\circ} \mathrm{C}$ \\
\hline \multirow[t]{3}{*}{ per unit-area } & beech/spruce & ns & ns & ns & ns & ns \\
\hline & spruce/mixed & ns & $*$ & ns & ns & ns \\
\hline & beech/mixed & ns & ns & ns & ns & $\mathrm{ns}$ \\
\hline \multirow[t]{3}{*}{ per unit-mass } & beech/spruce & ns & ns & ns & ns & $\mathrm{ns}$ \\
\hline & spruce/mixed & ns & $*$ & ns & ns & ns \\
\hline & beech/mixed & ns & ns & ns & ns & ns \\
\hline \multirow[t]{3}{*}{ per unit- $\mathrm{N}_{\mathrm{t}}$} & beech/spruce & ns & ns & ns & ns & $\mathrm{ns}$ \\
\hline & spruce/mixed & $*$ & $*$ & ns & ns & ns \\
\hline & beech $/$ mixed & $\mathrm{ns}$ & $\mathrm{ns}$ & $\mathrm{ns}$ & ns & $\mathrm{ns}$ \\
\hline
\end{tabular}

Figure 3. $\mathrm{N}_{2} \mathrm{O}$ emission rates from the forest floors of spruce, beech and mixed species stands related to area (a), dry matter (b) and $\mathrm{N}_{\text {total }}$ (c) as a function of temperature.

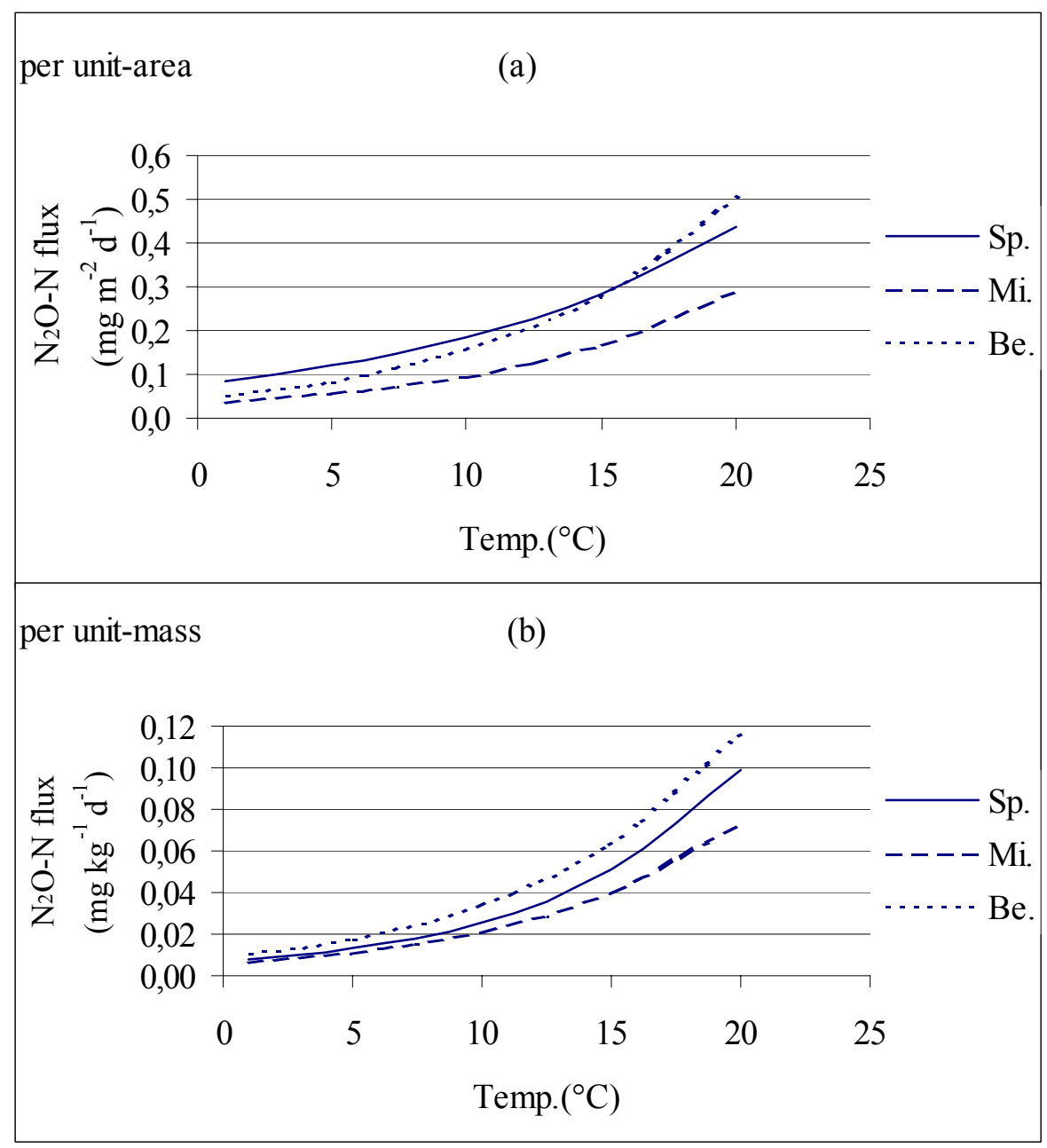




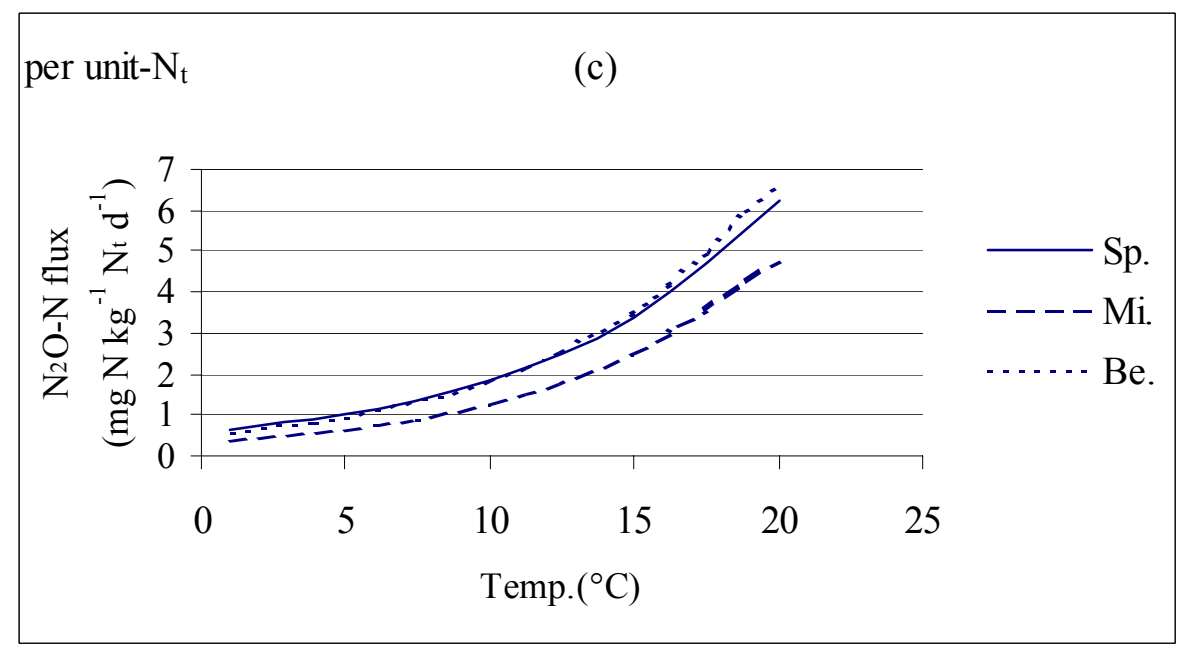

Figure 4. Average net $\mathrm{C}$-mineralization and $\mathrm{N}_{2} \mathrm{O}$ emissions related to units area $\left(\mathrm{g} \mathrm{Cm}^{-2} \mathrm{~d}^{-1}\right)$ or $\left(\mathrm{mg} \mathrm{N} \mathrm{m}^{-2} \mathrm{~d}^{-1}\right)$, mass $\left(\mathrm{g} \mathrm{C} \mathrm{kg}^{-1} \mathrm{~d}^{-1}\right)$ or $\left(\mathrm{mg} \mathrm{N} \mathrm{kg}^{-1} \mathrm{~d}^{-1}\right), \mathrm{C}_{\text {org }}\left(\mathrm{g} \mathrm{kg}^{-1} \mathrm{C}_{\text {org }} \mathrm{d}^{-1}\right)$ and and $\mathrm{N}_{\text {total }}(\mathrm{g}$ $\left.\mathrm{C} \mathrm{kg}^{-1} \mathrm{~N}_{\mathrm{t}} \mathrm{d}^{-1}\right)$ or $\left(\mathrm{mg} \mathrm{kg}^{-1} \mathrm{~N}_{\mathrm{t}} \mathrm{d}^{-1}\right)$, right $\mathrm{Y}$ axis.

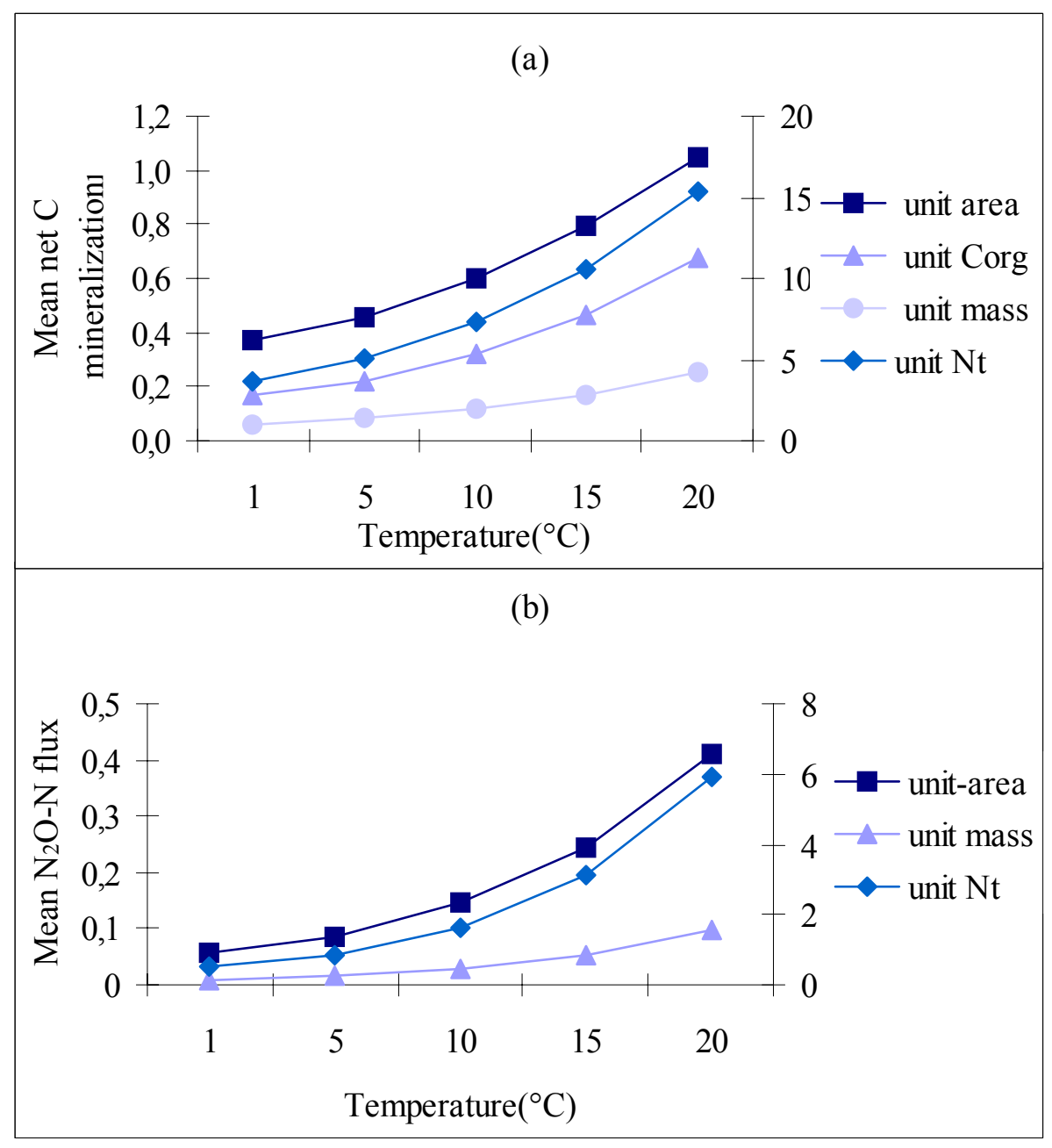




\subsection{Conclusion}

Nutrient concentration of the forest floors were less affected by tree species. In fact, site factors have confounded the effects of species, because the three stands developed under similar site conditions which influenced tree nutrition in pure and mixed species stands, also tree species may have implications for soil development due to similarity in forest floor element concentration and acidity.

Comparing the fitted curves in relation to temperature increase, revealed the similar pattern in net $\mathrm{C}$ mineralization and $\mathrm{N}_{2} \mathrm{O}$ emission rates at the three stands within the same temperature. The impact of increasing temperature on $\mathrm{N}_{2} \mathrm{O}$ emission rates due to higher $Q_{10}$ values was higher than on net $\mathrm{C}$ mineralization at the three stands, although the regulating factors such as moisture content were similar. It was demonstrated that under the same environmental conditions (Temperature and moisture) the emission rates of trace gases did not differ significantly between mono and mixed species cultures, exhibited the species-related effect on trace gases evolutions in adjacent forest floors were negligible. Reliable estimates of trace gas fluxes in forests are still required to provide a better understanding of the contribution of soil $\mathrm{CO}_{2}$ and $\mathrm{N}_{2} \mathrm{O}$ efflux to the carbon and nitrogen transformations in European forests. 


\section{Nitrogen mineralisation in $\mathrm{O}_{\mathrm{H}}$ horizons of beech, spruce and mixed forests affected by temperature and soil microbial status}

\subsection{Introduction}

Organic matter is of primary importance for nutrient availability and the sustainability of forest productivity. Essential nutrients are stored in organic matter like nitrogen and base cations and are available for plant uptake after mineralisation. However, organic matter accumulation at the soil surface (forest floor) can affect the forest ecosystem by immobilizing nutrients making them unavailable for plant uptake. The humus forms are useful indicators for estimating the immobilization and availability of nutrients in forest soils. The immobilization increase from mull humus to moder, or mor is a consequence of local ecological conditions particularly the climate, vegetation and parent material. Mull humus indicates a better nutrient availability, stores only $0.3 \mathrm{Mg} \mathrm{N} \mathrm{ha}^{-1}$ in contrast to mor humus with $1.3 \mathrm{Mg} \mathrm{N} \mathrm{ha}^{-1}$ estimated on 600 forest soil profiles in Germany (Wolff and Riek, 1997).

The present increase of organic matter in the forest floor from mull to mor humus indicates an exponentially increase in the $\mathrm{O}_{\mathrm{H}}$ horizon while the $\mathrm{O}_{\mathrm{L}} / \mathrm{O}_{\mathrm{F}}$ horizons follows an hyperbolic curve (Brumme et al., 2004) (Figure 1). The $\mathrm{O}_{\mathrm{L}} / \mathrm{O}_{\mathrm{F}}$ horizons were found to be the horizons with highest microbial activity and the hyperbolic increase suggest that with increasing soil acidity from mull to mor humus, the microorganisms build up a new decomposer refuge on the top of the mineral soil which is in the steady state between litter input and decomposition. In contrast to the $\mathrm{O}_{\mathrm{L}} / \mathrm{O}_{\mathrm{F}}$ horizons the $\mathrm{O}_{\mathrm{H}}$ horizon shows a potentially unlimited accumulation from mull to mor humus. Formation of recalcitrant humic compounds by humification in the $\mathrm{O}_{\mathrm{F}}$ horizon and their sequestration in the $\mathrm{O}_{\mathrm{H}}$ horizon seems to be the prevailing process in this horizon. The unlimited $\mathrm{C}$ accumulation in this horizon indicates that microbial decomposition did not equal the production of recalcitrant material.

To understand why the $\mathrm{O}_{\mathrm{H}}$ horizon shows an exponential increase, we should know the process of decomposition and the factors that control the rate of this process. Berg and McClaugherty (2003) presented a general model of decomposition from litter to humus in three stages. During the early stage, there is a very rapid loss of solubles and non-lignified carbohydrates whereas nutrients are limited and immobilized at the beginning. Once the litter reaches the second stage solubles and non-lignified carbohydrates are decomposed and mass loss is decreased and controlled by lignin decomposition rate. Finally, in the humus near third 
stage of decay, the litter decomposition rate is close to zero, coincides with net loss of lignin and is responsible for the exponential growth of organic matter in the $\mathrm{O}_{\mathrm{H}}$ horizon.

The present study aimed to characterize the dynamics of the net N-mineralization, microbial biomass and ergosterol content of the fungi population affected by different temperatures and litter quality in $\mathrm{O}_{\mathrm{H}}$ horizon of the forest floors of beech, spruce and mixed species stands to find the role of biochemical processes controlling the rate of $\mathrm{O}_{\mathrm{H}}$ development.

Figure 1. Carbon stock of the forest floor, the $\mathrm{O}_{\mathrm{L}} / \mathrm{O}_{\mathrm{F}}$, and $\mathrm{O}_{\mathrm{H}}$ horizons at ten different stages between mull to mor humus $(\mathrm{n}=500)$ (Adopted from Brumme et al. In preparation). The striped area represents studied forest floor.

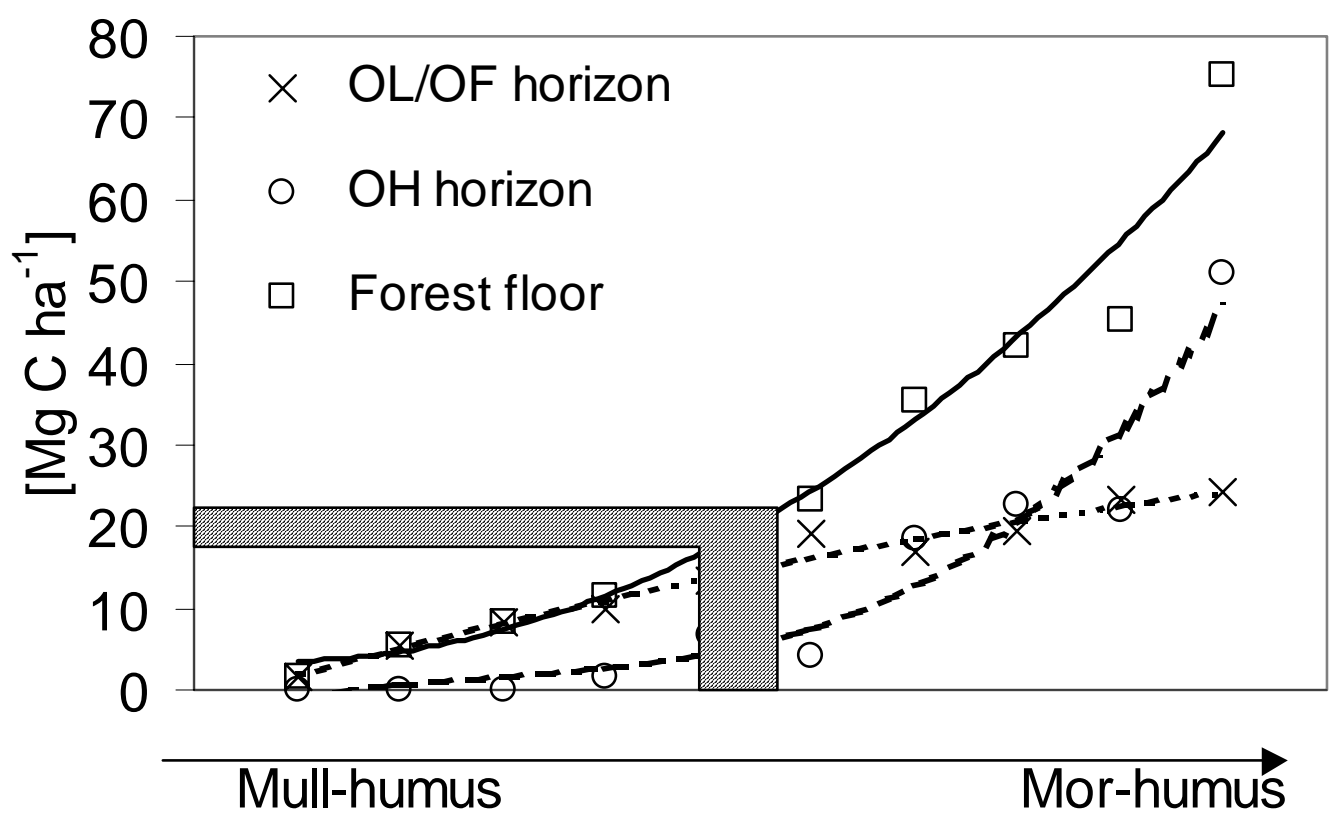




\subsection{Materials and Methods}

\subsubsection{Study site}

The study area is located at the Solling forest in Lower Saxony, Germany $\left(51^{\circ} 47^{\prime} \mathrm{N}\right.$ and $\left.9^{\circ} 37^{\prime} \mathrm{E}\right)$ at $500 \mathrm{~m}$ above see level. The climate is characterized by a mean annual temperature of $6.5^{\circ} \mathrm{C}$, a mean annual precipitation of $1050 \mathrm{~mm}$ and a frost-free period of 250 days . The annual temperatures range from an average of $14^{\circ} \mathrm{C}$ in July to an average of $-2^{\circ} \mathrm{C}$ in January. The dominant soil type are slightly podsolic Dystric Cambisol (FAO) developed on Triassic sandstone covered by a layer of loess with a thickness varying from 0.2 to $2 \mathrm{~m}$ (average 80 $\mathrm{cm})$. Soil texture is dominated by silty loam. The prevailing humus form is typical moder.

Three adjacent plots (area of about $400 \mathrm{~m}^{2}$ each) with 100 to 120 years old trees were chosen for the present study, one plot included Norway spruce (Picea abies L. karst), , another was covered by beech trees (Fagus sylvatica L.), and the third plot consisted of both, beech and spruce trees. There was a ground cover grass vegetation at the spruce stand which received an application of $2.3 \mathrm{t}$ dolomite ha ${ }^{-1}$ at 1989.

\subsubsection{Soil sampling and experimental design}

Thirty undisturbed field-moist humus samples (mention the size of the samples) were collected randomly at each plot in November 2001 by using a stainless steal auger. Twelve extra soil cores were collected of each stand for initial measurements of $\mathrm{C}, \mathrm{N}$ and microbial biomass. Samples were stored at $4{ }^{\circ} \mathrm{C}$ until incubation. The $\mathrm{O}_{\mathrm{H}}$ layers were sieved $(2 \mathrm{~mm})$ after removing the forest floor $\mathrm{O}_{\mathrm{L} / \mathrm{F}}$ layers. Samples were placed into incubation vessels $(8.4$ $\mathrm{cm}$ diameter, $14 \mathrm{~cm}$ height) and incubated at $1,5,10,15$, and $20^{\circ} \mathrm{C}$ with six replications from each stand at each temperature for three months. Moisture content was adjusted weekly with distilled water to maintain the initial water content.

\subsubsection{Soil analyses and statistical calculations}

Moisture content was determined on sub-samples by drying to constant weight at $105^{\circ} \mathrm{C}$. Microbial $\mathrm{C}\left(\mathrm{C}_{\text {mic }}\right)$ and $\mathrm{N}\left(\mathrm{N}_{\text {mic }}\right)$ were determined using the chloroform fumigation-extraction method (Brookes et al., 1985, Vance et al., 1987). The $\mathrm{C}$ and $\mathrm{N}$ flushes were converted tomicrobial biomass $\mathrm{C}$ and $\mathrm{N}$, respectively, using $k_{\mathrm{C}}=0.45$ (Joergensen, 1996) and $k_{\mathrm{N}}=0.54$ (Brookes et al., 1985). The Organic $\mathrm{C}$ in the $\mathrm{K}_{2} \mathrm{SO}_{4}$ extracts was analyzed by dry combustion 
at $680^{\circ} \mathrm{C}$ using TOC 5050 Shimadzu carbon analyzer (Shimadzu GmbH, Duisburg, Germany). The extracted ammonium, nitrate and total $\mathrm{N}$ were analysed by a continuous flow system spectrophotometer (Skalar Analytic GmbH, D-41812 Erkelenz, Germany) (Koenig and Fortmann, 1996). An initial sub-sample was analysed to determine total C and $\mathrm{N}$ by dry combustion in a $\mathrm{CN}$-auto analyser (Vario, Elementar Analysensysteme, Hanau, Germany) and soil $\mathrm{pH}$ (digital pH-meter, WTW GmbH Wesl-Germany). The quantification of fungal biomass were made by determination of ergosterol content. Ergosterol was measured according to Djajakirana et al. (1996). Moist soil of $1 \mathrm{~g}$ dry weight was extracted with $100 \mathrm{ml}$ ethanol for $30 \mathrm{~min}$ by oscillating shaking at $250 \mathrm{rev} \mathrm{min}^{-1}$. Ergosterol was measured by reversed-phase HPLC analysis at $25^{\circ} \mathrm{C}$ using a column of $12.5 \mathrm{~cm}$ Spherisorb ODS II S5 with a mobile phase of $97 \mathrm{vol} \%$ methanol / 3 vol\% water and detection at $282 \mathrm{~nm}$. The effect of temperature on net nitrogen mineralization was investigated by estimating the rate of increase of extractable ammonium and nitrate. Extractable ammonium and nitrate were determined by the extraction of $40 \mathrm{~g}$ soil with $200 \mathrm{ml} 0.5 \mathrm{~m} \mathrm{~K}_{2} \mathrm{SO}_{4}(\sim 5: 1$ ratio of solution to dry mass soil) after 12 weeks of incubation. Exponential function equation (1) was used to calculate the temperature effects on net nitrogen mineralization by a fitting procedure, where the parameters $b_{0}$ and $b_{1}$ were calculated.

$\mathrm{NNM}=b_{0} \times e^{(b 1 . T)}$

NNM is the net nitrogen mineralization and $T$ is the temperature $\left({ }^{\circ} \mathrm{C}\right)$.

The $Q_{10}$ function (2) was used to show temperature sensitivities of a complex of biochemical processes in soil, calculated as:

$Q_{10}=e^{(10 b 1)}$

Analysis of variance (ANOVA) were tested by Mann-Whitney U-Test at $\mathrm{P}<0.05$ level, performed by the program Statistica version 6.0. 


\subsection{Results and Discussion}

\subsubsection{Biochemical characteristics of $\mathbf{O}_{H}$ horizons}

The $\mathrm{O}_{\mathrm{H}}$ horizon increased slightly from beech over mixed species, to spruce forests but is not significantly different $(P<0.05)$ between the stands as was found for all biochemical characteristics in Table 1 . The $\mathrm{pH}$ of the $\mathrm{O}_{\mathrm{H}}$ horizons was very low and represented the overall median of $\mathrm{O}_{\mathrm{H}}$ horizions in Germany of about $3.0\left(\mathrm{pH}_{(\mathrm{KCl})}\right)$ (Wolff and Riek, 1997). The average C:N ratios of 20.8 were lower than the overall median of 24 in German moder humus (Wolff and Riek, 1997) which indicates a higher $\mathrm{N}$ immobilisation from $\mathrm{N}$ deposition at Solling. Lower soil $\mathrm{pH}$ and $\mathrm{C}: \mathrm{N}$ ratios as a result of high $\mathrm{N}$ and acid deposition during the last decades (Ulrich, 1994) indicated by former soils analysis of $\mathrm{pH}$ (Hallbäcken and Tamm, 1986; Heisner et al., 2003) and total nitrogen at solling (Zezschwitz, 1980; Buberl et al., 1994). The $\mathrm{O}_{\mathrm{H}}$ substrate quality was also found to be similar regarding the content of microbial biomass estimated in a survey of $\mathrm{O}_{\mathrm{H}}$ horizons in Lower Saxony, Germany (Anderson, 2004). The microbial biomass of the forest soils in Lower Saxony ranged from 1.3 to $2.8 \mathrm{mg} \mathrm{C} \mathrm{g}^{-1}$ with a high spatial variation of up to $0.9 \mathrm{mg} \mathrm{C} \mathrm{g}^{-1}$ which was not significantly different to the mean of $3.8 \mathrm{mg} \mathrm{C} \mathrm{g}^{-1}$ at the present study. As a result of the insignificant differences on initial characteristics of the $\mathrm{O}_{\mathrm{H}}$ horizon of the spruce stand in compare to the beech and mixed species stands even for the Ca content it can be assumed that the application of lime in 1989 has not significantly changed the $\mathrm{O}_{\mathrm{H}}$ horizon at the spruce stand.

Table 1. Mean initial $\mathrm{O}_{\mathrm{H}}$ horizon characteristics $(n=30)$ of the study area at the Solling forest, Germany. Data are presented on a dry matter basis. Standard deviation represent in parentheses. (Values are not significantly different at $P<0.05$ between the stands).

\begin{tabular}{|c|c|c|c|c|c|c|c|c|c|c|c|c|}
\hline \multirow[t]{2}{*}{ stand } & \multirow{2}{*}{$\begin{array}{l}\text { height } \\
(\mathrm{cm})\end{array}$} & \multirow{2}{*}{$\begin{array}{c}\text { mass } \\
\left(\mathrm{Mg} \mathrm{ha}^{-1}\right)\end{array}$} & \multirow{2}{*}{$\begin{array}{c}\text { moisture } \\
(\%)\end{array}$} & \multicolumn{2}{|c|}{$\mathrm{pH}$} & $\mathrm{C}_{\text {org }}$ & $\mathrm{N}_{\mathrm{t}}$ & \multirow[t]{2}{*}{$\mathrm{C} / \mathrm{N}$} & \multirow[t]{2}{*}{$\mathrm{C} / \mathrm{P}$} & $\mathrm{C}_{\text {mic-init. }}$ & $\mathrm{N}_{\text {mic-init. }}$ & \multirow[t]{2}{*}{$\mathrm{C}_{\mathrm{mid}} / \mathrm{N}_{\text {mic }}$} \\
\hline & & & & $\overline{(\mathrm{KCl})}$ & $\overline{\left(\mathrm{H}_{2} \mathrm{O}\right)}$ & \multicolumn{2}{|c|}{$\left(\mathrm{g} \mathrm{kg}^{-1}\right)$} & & & \multicolumn{2}{|c|}{$\left(\mu \mathrm{g} \mathrm{g}^{-1}\right)$} & \\
\hline beech & 2.78 & $\begin{array}{c}17.2 \\
(4.71)\end{array}$ & $\begin{array}{c}59.5 \\
(5.07)\end{array}$ & $\begin{array}{l}3.00 \\
(0.14)\end{array}$ & $\begin{array}{r}3.68 \\
(0.19)\end{array}$ & $\begin{array}{c}251 \\
(48.3)\end{array}$ & $\begin{array}{c}12.9 \\
(2.52)\end{array}$ & $\begin{array}{c}19.6 \\
(1.32)\end{array}$ & $\begin{array}{c}257 \\
(48,6)\end{array}$ & $\begin{array}{l}3686 \\
(570)\end{array}$ & $\begin{array}{c}438 \\
(70.5)\end{array}$ & $\begin{array}{c}8.44 \\
(0.53)\end{array}$ \\
\hline spruce & 4.02 & $\begin{array}{c}20.1 \\
(8.53)\end{array}$ & $\begin{array}{l}63.2 \\
(5.6)\end{array}$ & $\begin{array}{c}3.21 \\
(0.58)\end{array}$ & $\begin{array}{r}4.04 \\
(0.62)\end{array}$ & $\begin{array}{c}259 \\
(54.5)\end{array}$ & $\begin{array}{c}11.9 \\
(2.39)\end{array}$ & $\begin{array}{c}21.8 \\
(1.71)\end{array}$ & $\begin{array}{c}344 \\
(72,4)\end{array}$ & $\begin{array}{l}3757 \\
(629)\end{array}$ & $\begin{array}{c}381 \\
(75.1)\end{array}$ & $\begin{array}{c}9.94 \\
(0.60)\end{array}$ \\
\hline mixed & 3.66 & $\begin{array}{c}18.5 \\
(7.65)\end{array}$ & $\begin{array}{c}63.5 \\
(3.66)\end{array}$ & $\begin{array}{l}2.96 \\
(0.09)\end{array}$ & $\begin{array}{r}3.79 \\
(0.13)\end{array}$ & $\begin{array}{c}280 \\
(44.9)\end{array}$ & $\begin{array}{c}13.4 \\
(2.56)\end{array}$ & $\begin{array}{c}21.1 \\
(1.78)\end{array}$ & $\begin{array}{c}329 \\
(51,8)\end{array}$ & $\begin{array}{l}3980 \\
(602)\end{array}$ & $\begin{array}{c}451 \\
(51.5)\end{array}$ & $\begin{array}{c}8.83 \\
(1.01)\end{array}$ \\
\hline
\end{tabular}




\subsubsection{Net $\mathrm{N}$-mineralization affected by litter quality and temperature}

The rates of NNM increased exponentially $\left(R^{2}=0.91-0.99\right)$ with increase in the incubation temperature in the range of $1-20^{\circ} \mathrm{C}$ during 12 weeks incubation period at the three stands (Figure 2). In comparison to beech and mixed speciesstands the rates of net $\mathrm{N}$ mineralization at spruce stand was slightly higher within the same temperature, resulting from higher accumulation of humus in the $\mathrm{O}_{\mathrm{H}}$ horizon of spruce stand (Table 2). However, the NNM was statistically not different $(0.05>P>0.01)$ between the mono and mixed species cultures except at $10^{\circ} \mathrm{C}$ for beech and spruce stands, and revealed no distinct effect of different tree litter qualities on NNM. By using the exponential function (1) the NNM has been calculated for $6.5^{\circ} \mathrm{C}$, the mean annual air temperature of the study area (Table 3 ). The differences in NNM between the stands by mean annual air temperature were small independent from the measured unit (area, total mass of $\mathrm{O}_{\mathrm{H}}, \mathrm{C}_{\text {org }}, \mathrm{N}_{\mathrm{t}}$ ) (Table 4). As a result of the prevailing insignificant differences between the stands the mean net $\mathrm{N}$ mineralization is calculated and shown in figure 3. The general pattern of results showed a significant increase in net mineralization rate of nitrogen with increase of temperature at each stand. The observed increase in net $\mathrm{N}$ mineralization is consistent with results from individual sites, which have demonstrated significant positive relationships between temperature and net $\mathrm{N}$ mineralization (Van Cleve et al., 1990; Emmer and Tietema, 1990; Bonan and Van Cleve, 1991; Goncalves and Caryle, 1994; MacDonald et al., 1995; Reich et al., 1997; Rustad et al., 2000). The $Q_{10}$ coefficients calculated by function (2) considered as indicator of NNM sensitivity to temperature increase amounted to an average of 2.4 (Table 4). The temperature sensitivity of the net $\mathrm{N}$ mineralization $\left(\mathrm{Q}_{10}\right.$ values) in $\mathrm{O}_{\mathrm{H}}$ horizon of the three stands ranged from 2.24 to 2.63 between the stands dependent on the related units (Table 3). In consistent, Dalias et al. (2002) reported the $Q_{10}$ values of native $\mathrm{N}$ mineralization in $\mathrm{O}_{\mathrm{H}}$ horizon of the conifer forest soils in the range of $1.69-2.48$ at the incubation temperature of 10 to $20^{\circ} \mathrm{C}$. The differences on the temperature response of net $\mathrm{N}$ mineralization along the temperature increase suggests that the increase in stabilization intensify as temperature increases, could ultimately be the cause for the small differences in $Q_{10}$ values between the stands (Table 3). Responses of $\mathrm{O}_{\mathrm{H}}$ $\mathrm{N}$-mineralization to temperature increase may not only be dependent on the $\mathrm{N}$ storage and organic matter stability in this horizon but also on the relationship between temperature response function and organic matter recalcitrance (Post et al., 1985; Anderson. 1991, 1992). 
Table 2. Mean Net $\mathrm{N}$ mineralization in the forest floor of spruce, beech and mixed species stands along the temperature increase over the incubation period $(n=6)$. Standard deviation is given in parentheses.

\begin{tabular}{|c|c|c|c|c|c|c|}
\hline \multirow{2}{*}{$\begin{array}{c}\text { Net } \mathrm{N} \\
\text { Mineralization }\end{array}$} & \multirow[t]{2}{*}{ stand } & \multicolumn{5}{|c|}{ Temperature $\left({ }^{\circ} \mathrm{C}\right)$} \\
\hline & & 1 & 5 & 10 & 15 & 20 \\
\hline \multirow{3}{*}{$\begin{array}{l}\text { per unit-area } \\
\left(\mathrm{mg} \mathrm{N} \mathrm{m}^{-2} \mathrm{~d}^{-1}\right)\end{array}$} & beech & $5.49(3.82)$ & $12.1(1.54)$ & $17.8(2.30)$ & $31.8(6.59)$ & $47.5(11.9)$ \\
\hline & spruce & $8.08(4.48)$ & $16.8(7.43)$ & $22.1(2.86)$ & $35.8(7.75)$ & $50.9(16.8)$ \\
\hline & mixed & $7.04(2.61)$ & $15.9(5.99)$ & $20.3(4.46)$ & $31.6(4.95)$ & $50.8(5.67)$ \\
\hline \multirow{3}{*}{$\begin{array}{l}\text { per unit-mass } \\
\left(\mathrm{mg} \mathrm{N} \mathrm{kg}^{-1} \mathrm{~d}^{-1}\right)\end{array}$} & beech & $3.08(2.09)$ & $7.06(1.70)$ & $12.0(2.91)$ & $24.9(4.64)$ & $27.5(4.88)$ \\
\hline & spruce & $3.14(1.73)$ & $6.48(2.49)$ & $16.4(0.97)$ & $22.9(8.89)$ & $30.0(8.16)$ \\
\hline & mixed & $2.52(0.92)$ & $9.52(3.21)$ & $15.4(6.44)$ & $24.0(4.70)$ & $31.4(8.36)$ \\
\hline \multirow{3}{*}{$\begin{array}{c}\text { per unit- } \mathrm{C}_{\text {org }} \\
\left(\mathrm{mg} \mathrm{N} \mathrm{kg} \mathrm{C}_{\text {org }}^{-1} \mathrm{~d}^{-1}\right)\end{array}$} & beech & $11.7(6.00)$ & $30.0(1.90)$ & $47.7(6.19)$ & $91.6(7.68)$ & $106(13.8)$ \\
\hline & spruce & $11.5(4.16)$ & $31.4(13.1)$ & $56.5(7.71)$ & 89.8 (19.7) & $108(21.8)$ \\
\hline & Mixed & $8.66(3.13)$ & $33.8(9.19)$ & $52.5(13.1)$ & $79.5(14.4)$ & $122(22.9)$ \\
\hline \multirow{3}{*}{ 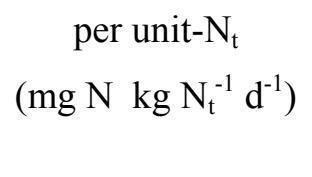 } & beech & $238(120)$ & $586(62.5)$ & 873 (123) & $1820(226)$ & $2086(288)$ \\
\hline & spruce & $278(97.2)$ & $627(243)$ & $1166(128)$ & $2030(540)$ & $2311(363)$ \\
\hline & mixed & $200(66)$ & $670(172)$ & $1047(256)$ & $1670(271)$ & $2532(467)$ \\
\hline
\end{tabular}


Table 3. $Q_{10}$ and Parameters of the $Q_{10}$ regressions $\left(F=b_{0} \cdot e^{(b 1 . T)}\right)$ fitted on the average net $\mathrm{N}$ mineralization data at the study area and the calculated NNM at mean of annual air temperature in Solling.

\begin{tabular}{ccccccc}
\hline Net N-mineralization & stand & $b_{0}$ & $b_{1}$ & $R^{2}$ & $Q_{10}$ & $\begin{array}{c}\mathrm{NNM} \\
\text { at } 6.5^{\circ} \mathrm{C}\end{array}$ \\
\hline per unit-area & beech & 7.00 & 0.10 & 0.99 & 2.63 & 13.1 \\
$\left(\mathrm{mg} \mathrm{N} \mathrm{m}^{-2} \mathrm{~d}^{-1}\right)$ & spruce & 9.95 & 0.08 & 0.99 & 2.28 & 17.0 \\
& mixed & 8.39 & 0.09 & 0.99 & 2.46 & 15.1 \\
per unit-mass & beech & 5.34 & 0.09 & 0.91 & 2.37 & 9.36 \\
$\left(\mathrm{mg} \mathrm{N} \mathrm{kg}^{-1} \mathrm{~d}^{-1}\right)$ & spruce & 5.67 & 0.09 & 0.94 & 2.36 & 9.91 \\
& mixed & 6.02 & 0.08 & 0.95 & 2.34 & 10.5 \\
per unit- $\mathrm{Corg}_{\text {or }}$ & beech & 21.0 & 0.08 & 0.93 & 2.32 & 36.3 \\
$\left(\mathrm{mg} \mathrm{N} \mathrm{kg} \mathrm{C}_{\text {org }}^{-1} \mathrm{~d}^{-1}\right)$ & spruce & 22.9 & 0.08 & 0.93 & 2.24 & 38.7 \\
& mixed & 18.7 & 0.09 & 0.98 & 2.57 & 34.6 \\
per unit- $\mathrm{N}_{\mathrm{t}}$ & beech & 401 & 0.09 & 0.92 & 2.37 & 701 \\
$\left(\mathrm{mg} \mathrm{N} \mathrm{kg} \mathrm{N}_{\mathrm{t}}^{-1} \mathrm{~d}^{-1}\right)$ & spruce & 489 & 0.08 & 0.92 & 2.26 & 831 \\
& mixed & 378 & 0.10 & 0.98 & 2.61 & 706 \\
\hline
\end{tabular}

Table 4. $Q_{10}$ and Parameters of the $Q_{10}$ regressions $\left(F=b_{0} \cdot e^{(b 1 . T)}\right)$ fitted on the average net Nmineralization data at the study area and the calculated NNM at mean of the three stands by mean annual air temperature in Solling.

\begin{tabular}{cccccc}
\hline $\begin{array}{c}\text { Net N- } \\
\text { mineralization }\end{array}$ & $b_{0}$ & $b_{1}$ & $R^{2}$ & $Q_{10}$ & $\begin{array}{c}\mathrm{NNM} \\
\text { at } 6.5^{\circ} \mathrm{C}\end{array}$ \\
\hline $\begin{array}{c}\text { per unit-area } \\
\left(\mathrm{mg} \mathrm{N} \mathrm{m}^{-2} \mathrm{~d}^{-1}\right)\end{array}$ & 8.43 & 0.09 & 0.99 & 2.44 & 15.05 \\
$\begin{array}{c}\text { per unit-mass } \\
\left(\mathrm{mg} \mathrm{N} \mathrm{kg}^{-1} \mathrm{~d}^{-1}\right)\end{array}$ & 5.68 & 0.09 & 0.95 & 2.35 & 9.91 \\
$\begin{array}{c}\text { per unit- } \mathrm{C}_{\text {org }} \\
\left(\mathrm{mg} \mathrm{N} \mathrm{kg}^{-1} \mathrm{C}_{\text {org }} \mathrm{d}^{-1}\right)\end{array}$ & 20.9 & 0.09 & 0.96 & 2.37 & 36.6 \\
$\begin{array}{c}\text { per unit- } \mathrm{N}_{\mathrm{t}} \\
\left(\mathrm{mg} \mathrm{N} \mathrm{kg}^{-1} \mathrm{~N}_{\mathrm{t}} \mathrm{d}^{-1}\right)\end{array}$ & 423 & 0.09 & 0.96 & 2.40 & 748 \\
\hline
\end{tabular}


Figure 2. Net $\mathrm{N}$-mineralization in $\mathrm{O}_{\mathrm{H}}$ layer of the forest floor of spruce, beech and mixed species stands related to area (a), dry matter (b), $\mathrm{C}_{\text {org }}$ (c) and $\mathrm{N}_{\text {total }}$ (d) as a function of temperature.

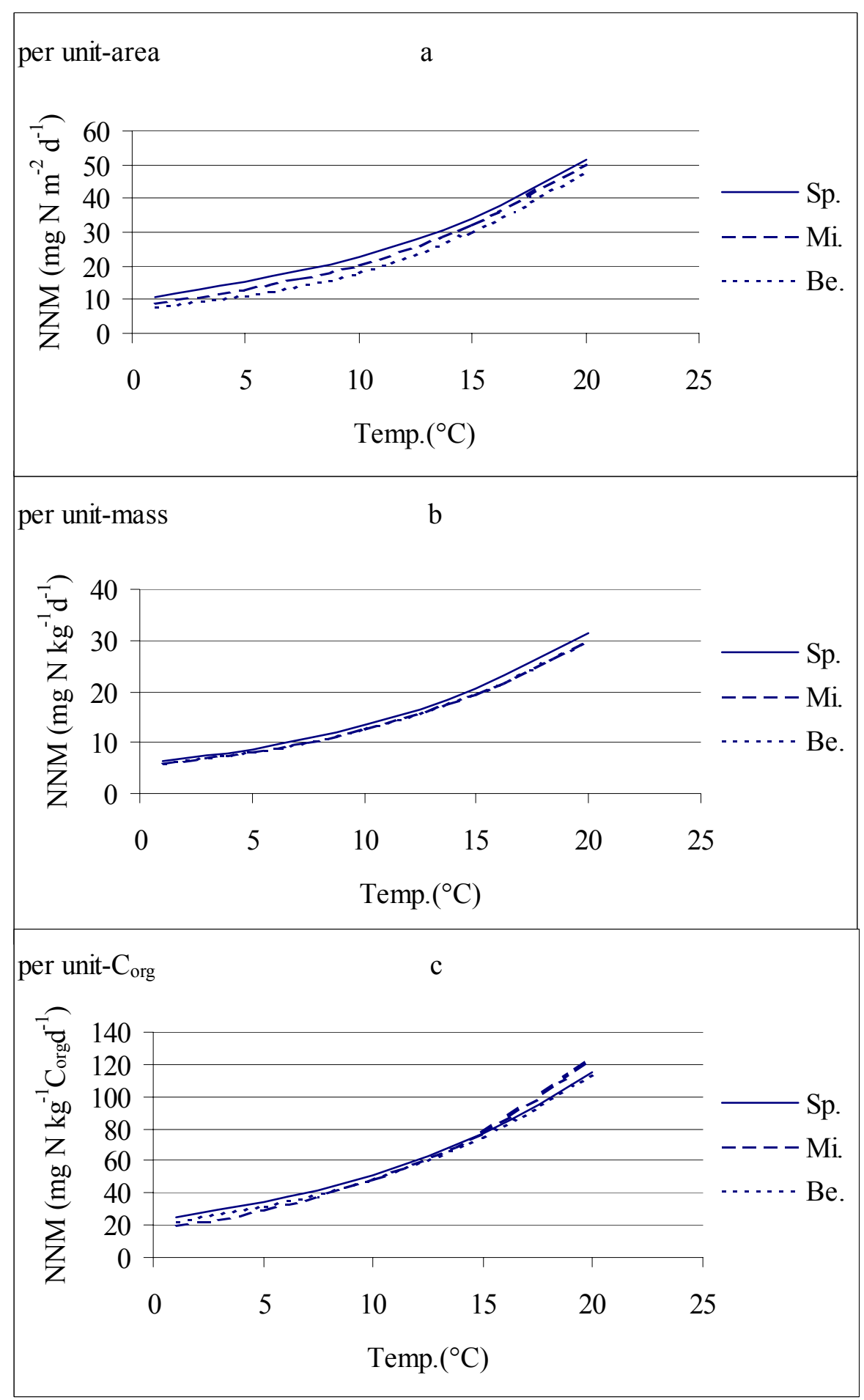




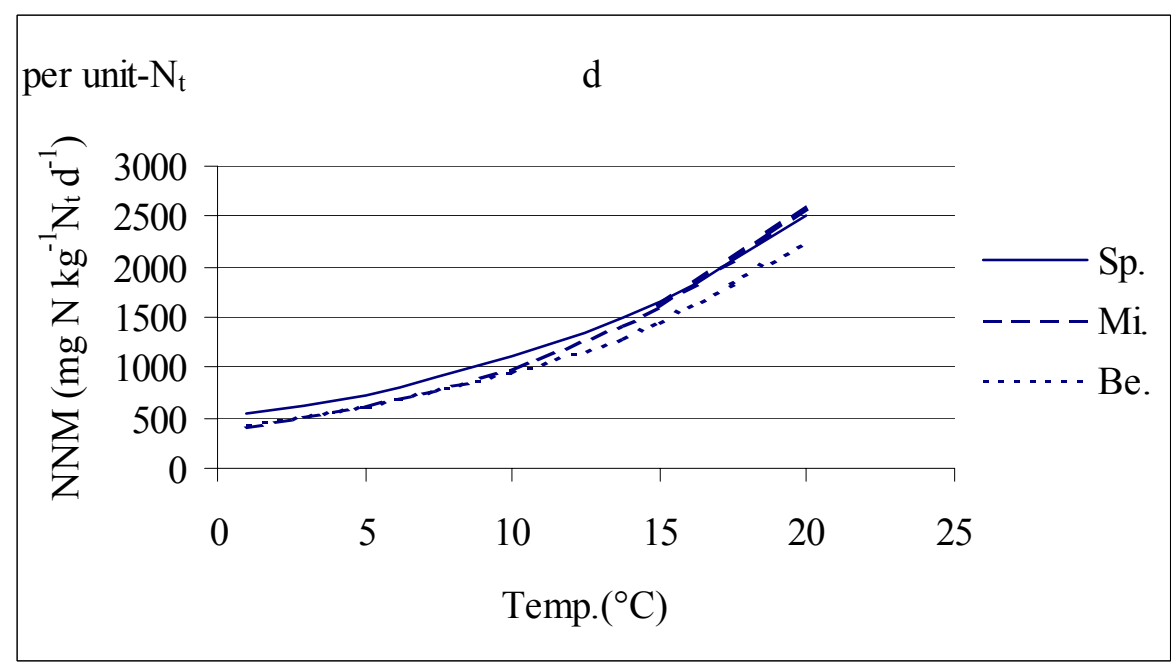

Figure 3. Average net $\mathrm{N}$-mineralization of the $\mathrm{O}_{\mathrm{H}}$ layer of the forest floors at different incubation temperatures related to units $\mathrm{C}_{\text {org }}\left(\mathrm{mg} \mathrm{kg}^{-1} \mathrm{C}_{\text {org }} \mathrm{d}^{-1}\right)$, area $\left(\mathrm{mg} \mathrm{m}^{-2} \mathrm{~d}^{-1}\right)$, dry matter ( $\left.\mathrm{mg} \mathrm{kg}^{-1} \mathrm{~d}^{-1}\right)$ and $\mathrm{N}_{\text {total }}\left(\mathrm{mg} \mathrm{kg}^{-1} \mathrm{~N}_{\mathrm{t}} \mathrm{d}^{-1}\right.$, right $\mathrm{Y}$ axis).

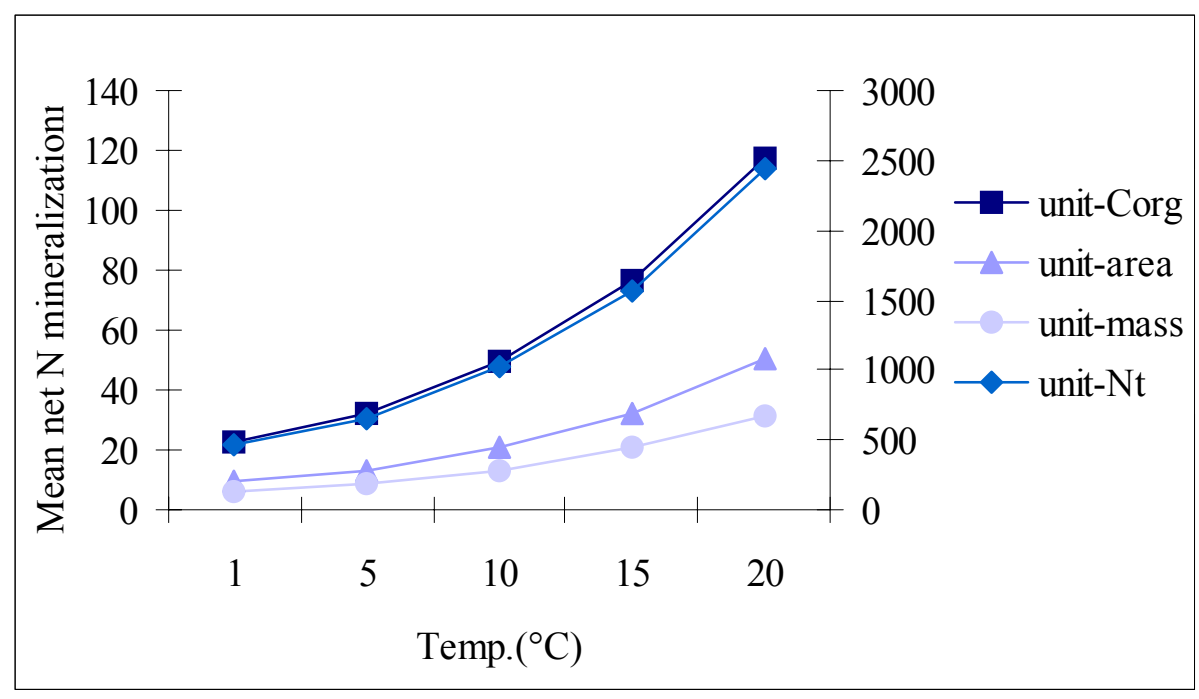




\subsubsection{Microbial biomass and ergosterol content affected by litter quality and temperature}

The values of microbial biomass $\mathrm{C}$ and $\mathrm{N}$ were not significantly different between the stands indicated at the begin (Table 1) and at the end of the experiment (Table 5). Temperature did not change the microbial biomass significantly between 1 to $15^{\circ} \mathrm{C}$ at each stand independent of the measured units (area, total mass of $\mathrm{O}_{\mathrm{H}}, \mathrm{C}_{\mathrm{org}}, \mathrm{N}_{\mathrm{t}}$ ). It is indicated that the increase of NNM with temperature was not related to the microbial biomass $\mathrm{C}$ and $\mathrm{N}$. This is in accordance with the results of the authors who found no relation between $\mathrm{N}$ mineralization rate and microbial biomass $\mathrm{N}$ to temperature variations in a beech forest soil (Bauhus and Barthel, 1995), coniferous forest soil (Raubuch and Joergensen, 2002), and in the litter of beech and coniferous forests (Poehhacker and Zech, 1995; Raubuch, 1998). The $\mathrm{C}_{\mathrm{mic}} / \mathrm{N}_{\text {mic }}$, $\mathrm{C}_{\text {mic }} / \mathrm{C}_{\text {org }}$ and the $\mathrm{N}_{\text {mic }} / \mathrm{N}_{\mathrm{t}}$ ratios remained relatively constant in the temperature range of 1 to $15^{\circ} \mathrm{C}$. The ergosterol concentration, a measure of the fungal biomass, was not affected by temperature but the values were significantly lower under spruce in contrast to the beech and mixed species stands as related to units mass and $\mathrm{C}_{\text {org }}$ (Table 6). This result is not consistant with the survey of fungal-to-bacterial ratios of the forest soils in north Germany which indicates higher ratios under coniferous forests. Blagodatskaya and Anderson (1998) found fungal-to-bacterial ratios of 90-to-10 and 94-to-6 in forty spruce and beech stands with low soil $\mathrm{pH}_{(\mathrm{KCl})}$ of about 3. At higher soil $\mathrm{pH}_{(\mathrm{KCl})}$ of 6 much lower ratios of 84-to-16 and 74-to-26 were found for spruce and beech stands. An explanation for this discrepancy could be the lime application at the spruce stand in 1989. Liming changed the soil chemical state only for a couple of years (AFZ-Heft, 1995) but has obviously a long-lasting effect on the microbial community. Significant changes in the microbial status occurred above $15{ }^{\circ} \mathrm{C}$, a soil temperature which is normally not passed at Solling. The microbial biomass $\mathrm{C}_{\text {mic }}$ and $\mathrm{N}_{\text {mic }}$, which were constant between 1 and $15^{\circ} \mathrm{C}$, significantly decreased at $20^{\circ} \mathrm{C}$ at the three stands. $\mathrm{C}_{\text {mic }}$ contributed $1.0-1.8 \%$ of total organic $\mathrm{C}$ in $\mathrm{O}_{\mathrm{H}}$ horizon in the temperature range of 1 $15^{\circ} \mathrm{C}$ and $0.46-0.77 \%$ at $20^{\circ} \mathrm{C}$ (Table 5) and (Figure 4). The $\mathrm{C}_{\text {mic }}$-to- $\mathrm{C}_{\text {org }}$ ratio, an internal indicator of how much of the organic carbon is available for microbial growth decreased at $20^{\circ} \mathrm{C}$ and reflect a higher carbon demand due to higher microbial activity. In contrast to bacteria the ergosterol content was not significantly affected at the temperature of $20^{\circ} \mathrm{C}$, although a trend to lower contents occurred per units mass and $\mathrm{C}_{\text {org }}$ at beech and mixed species stands (Table 6). As a consequence, the temperature effect on the ergosterol-to- $\mathrm{C}_{\text {mic }}$ 
ratios was higher at spruce stand and reached the same values as was found for beech and mixed species stands.

Table 5. Microbial C and N, $\mathrm{C}_{\text {mic }}-\mathrm{to}_{\mathrm{mic}} \mathrm{N}_{\text {mic }}$ ratio, $\mathrm{N}_{\text {mic }}-\mathrm{to}_{\mathrm{t}}-\mathrm{N}_{\mathrm{t}}$ in $\mathrm{O}_{\mathrm{H}}$ horizon of the forest floor of the three stands at different incubation temperatures $(n=6)$, standard deviation is given in parentheses. (Values are not significantly different at $\mathrm{P}<0.05$ between the sites at each temperature).

\begin{tabular}{|c|c|c|c|c|c|c|}
\hline \multirow{2}{*}{$\begin{array}{c}\text { Temperature } \\
\left({ }^{\circ} \mathrm{C}\right)\end{array}$} & \multirow[t]{2}{*}{ stand } & $\mathrm{C}_{\mathrm{mic}}$ & $\mathrm{N}_{\text {mic }}$ & \multirow{2}{*}{$\mathrm{C}_{\mathrm{mic}} / \mathrm{N}_{\mathrm{mic}}$} & $\mathrm{C}_{\text {mic }} / \mathrm{C}_{\text {org }}$ & $\mathrm{N}_{\text {mic }} / \mathrm{N}_{\mathrm{t}}$ \\
\hline & & \multicolumn{2}{|c|}{$\left(\mu \mathrm{gg}^{-1}\right)$} & & \multicolumn{2}{|c|}{$(\%)$} \\
\hline \multirow[t]{3}{*}{1} & beech & $4453(1060)$ & $453(146)$ & $10.1(1.28)$ & $1.76(0.23)$ & $3.77(0.88)$ \\
\hline & spruce & $4031(802)$ & $351(76.2)$ & $11.6(1.83)$ & $1.50(0.07)$ & $3.16(0.49)$ \\
\hline & mixed & 4234 (563) & $448(103)$ & $9.68(1.50)$ & $1.58(0.40)$ & $4.01(1.75)$ \\
\hline \multirow[t]{3}{*}{5} & beech & 3367 (680) & $325(63.0)$ & $10.4(0.38)$ & $1.46(0.28)$ & $2.88(0.50)$ \\
\hline & spruce & $3168(845)$ & $334(215)$ & $10.8(2.94)$ & $1.52(0.33)$ & $3.21(2.05)$ \\
\hline & mixed & 3839 (538) & 352 (44.9) & $10.9(0.83)$ & $1.40(0.13)$ & $2.54(0.28)$ \\
\hline \multirow[t]{3}{*}{10} & beech & 3628 (894) & $377(111)$ & $9.72(0.57)$ & $1.44(0.17)$ & $2.72(0.40)$ \\
\hline & spruce & $3016(558)$ & $279(63.3)$ & $10.9(0.98)$ & $1.02(0.14)$ & $1.95(0.33)$ \\
\hline & mixed & $3608(760)$ & $379(79.6)$ & $9.56(0.97)$ & $1.27(0.09)$ & $2.66(0.25)$ \\
\hline \multirow[t]{3}{*}{15} & beech & 4520 (967) & $484(120)$ & $9.42(0.59)$ & $1.66(0.19)$ & $3.54(0.72)$ \\
\hline & spruce & 3027 (665) & $286(70.3)$ & $10.7(0.83)$ & $1.21(0.16)$ & $2.52(0.21)$ \\
\hline & mixed & $3616(581)$ & 373 (71.4) & $9.77(0.63)$ & $1.19(0.11)$ & $2.61(0.53)$ \\
\hline \multirow[t]{3}{*}{20} & beech & $1950(430)$ & $273(63.8)$ & $7.19(0.86)$ & $0.77(0.09)$ & $2.14(0.37)$ \\
\hline & spruce & 1246 (399) & $150(70.3)$ & $9.49(4.48)$ & $0.46(0.12)$ & $1.16(0.38)$ \\
\hline & mixed & $1900(524)$ & $236(40.3)$ & $8.02(1.59)$ & $0.72(0.08)$ & $1.92(0.23)$ \\
\hline
\end{tabular}


Figure 4. Microbial biomass $\left(\% \mathrm{C}_{\mathrm{mic}}\right.$ in $\left.\mathrm{C}_{\mathrm{org}}\right)$ in $\mathrm{O}_{\mathrm{H}}$ layer of the forest floors affected by temperature and litter quality.

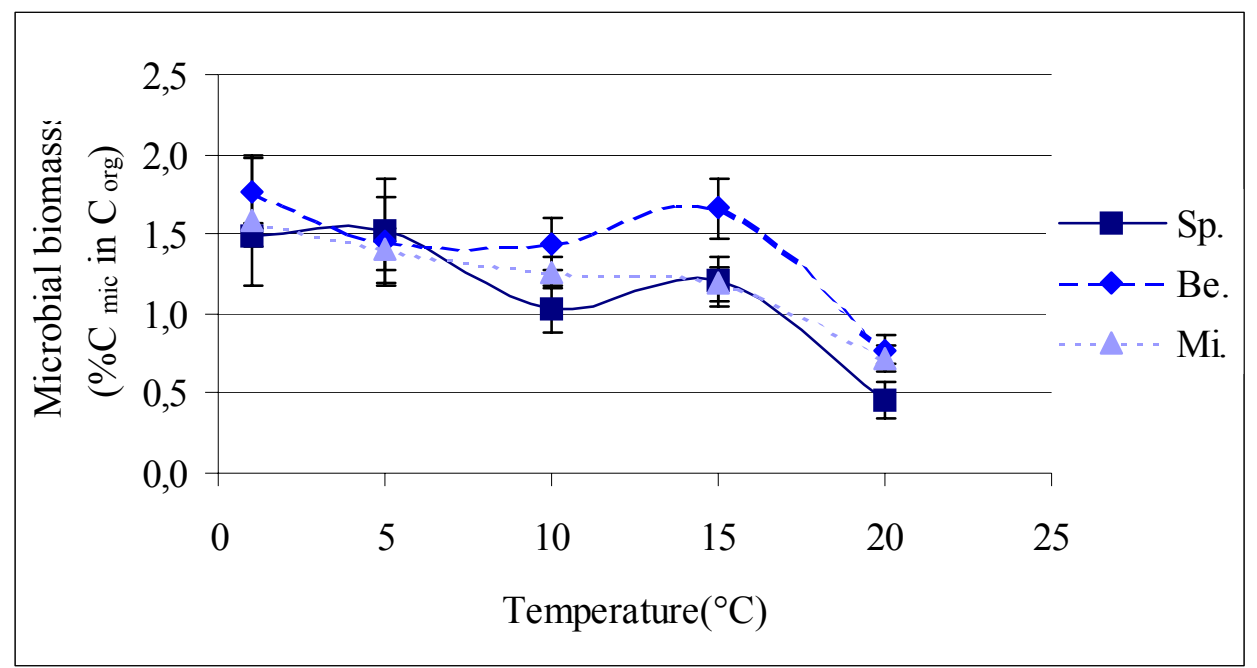

Table 6. Ergosterol content of fungal biomass in $\mathrm{O}_{\mathrm{H}}$ horizon of the forest floor of the three stands at different incubation temperatures $(n=6)$. Standard deviation represent in parentheses.

\begin{tabular}{|c|c|c|c|c|c|c|}
\hline \multirow[t]{2}{*}{ Fungal ergosterol } & \multirow[t]{2}{*}{ stand } & \multicolumn{5}{|c|}{ Temperature $\left({ }^{\circ} \mathrm{C}\right)$} \\
\hline & & 1 & 5 & 10 & 15 & 20 \\
\hline \multirow{3}{*}{$\begin{array}{l}\text { per unit-mass } \\
\left(\mu \mathrm{g} \text { sterol } \mathrm{g}^{-1}\right)\end{array}$} & beech & $27.2(7.02)$ & $28.8(12.0)$ & $32.1(9.21)$ & $31.1(7.31)$ & $22.3(4.78)$ \\
\hline & spruce & $15.5(6.60)$ & $9.83(2.36)$ & $14.0(5.34)$ & $10.0(3.40)$ & $12.3(5.22)$ \\
\hline & mixed & $24.1(3.73)$ & $24.2(2.90)$ & $25.4(6.13)$ & $29.4(8.86)$ & $21.2(3.15)$ \\
\hline \multirow{3}{*}{$\begin{array}{c}\text { per unit- } \mathrm{C}_{\text {org }} \\
\left(\mu \mathrm{g} \text { sterol } \mathrm{g}_{\text {org }}^{-1}\right)\end{array}$} & beech & $112(21.1)$ & $119(22.4)$ & $127(18.0)$ & $114(17.4)$ & $88.5(10.7)$ \\
\hline & spruce & $55.8(16.3)$ & $47.9(13.5)$ & $46.8(14.6)$ & $38.8(9.54)$ & $44.1(15.0)$ \\
\hline & mixed & 87.4 (7.6) & 89.0 (11.7) & $88.7(9.36)$ & $96.5(24.0)$ & $82.9(10.7)$ \\
\hline \multirow{3}{*}{$\begin{array}{c}\text { per unit- } \mathrm{C}_{\mathrm{mic}} \\
\left(\mu \mathrm{g} \text { sterol } \mathrm{mg} \mathrm{C}_{\mathrm{mic}}^{-1}\right)\end{array}$} & beech & $6.16(1.15)$ & $8.58(3.17)$ & $8.88(1.50)$ & $6.81(0.94)$ & $11.7(2.41)$ \\
\hline & spruce & $3.77(1.16)$ & $3.35(1.38)$ & $4.42(1.44)$ & $3.29(1.07)$ & $11.2(7.75)$ \\
\hline & Mixed & $5.81(1.46)$ & $6.36(0.67)$ & $7.06(1.03)$ & $8.16(2.03)$ & $11.8(3.20)$ \\
\hline
\end{tabular}




\subsubsection{Specific net $\mathbf{N}$ mineralization}

The specific $\mathrm{NNM}\left(\mathrm{NNM} / \mathrm{C}_{\text {mic }}\right)$ were calculated assuming a linear change in microbial biomass over the incubation period. Specific NNM increased significantly from 0.61 to 11.9 ( $\mu \mathrm{g} \mathrm{N} \mathrm{mg}{ }^{-1} \mathrm{C}_{\text {mic }} \mathrm{d}^{-1}$ ) between 1 to $20^{\circ} \mathrm{C}$ without significant differences between the stands (Table 7). The high correlation $\left(R^{2}>0.98\right)$ indicated that the decline in bacterial biomass at $20^{\circ} \mathrm{C}$ seems to have no influence on the specific NNM. This result was not expected for three reasons. A decline in microbial biomass at $20^{\circ} \mathrm{C}$ provide an easy available substrate for decomposition and a lower microbial biomass immobilize less nitrogen. A higher proportion of fungal biomass should reduce the $\mathrm{N}$ immobilization due to the higher $\mathrm{C} / \mathrm{N}$ ratio compared to bacteria (Killham, 1994). The higher energy metabolism to maintain the lower microbial biomass at $20^{\circ} \mathrm{C}$ may have reduced the growth and $\mathrm{N}$ immobilization. There might be two reasons for this discrepancy, either the microbial biomass has not been changed linear during incubation or the total effect on NNM listed above were negligible.

Table 7. Specific net N-mineralization in $\mathrm{O}_{\mathrm{H}}$ horizon of the forest floor of the three stands at different incubation temperatures $(n=6)$. Standard deviation represent in parentheses.

\begin{tabular}{ccccccc}
\hline & Stand & \multicolumn{5}{c}{ Temperature $\left({ }^{\circ} \mathrm{C}\right)$} \\
\cline { 3 - 7 } & & 1 & 5 & 10 & 15 & 20 \\
\hline $\mathrm{NNM} / \mathrm{C}_{\text {mic }}$ & beech & $0.72(0.43)$ & $1.99(0.40)$ & $3.25(0.53)$ & $5.95(0.52)$ & $9.53(1.48)$ \\
$\left(\mu \mathrm{g} \mathrm{N} \mathrm{mg} \mathrm{C}_{\left.\text {mic }^{-1} \mathrm{~d}^{-1}\right)}\right.$ & spruce & $0.80(0.37)$ & $1.88(0.78)$ & $4.87(0.36)$ & $6.81(2.43)$ & $11.9(2.24)$ \\
& mixed & $0.61(0.19)$ & $2.40(0.71)$ & $3.94(1.28)$ & $6.28(1.12)$ & $10.5(2.31)$ \\
\hline
\end{tabular}




\subsection{Conclusion}

Litter from different tree species did not result in changes in biochemical properties of $\mathrm{O}_{\mathrm{H}}$ horizons in over 120 years old beech, spruce, and mixed species forests. In addition, similar microbial biomass, ergosterol content, and specific NNM suggest no differences in substrate quality of the $\mathrm{O}_{\mathrm{H}}$ horizons. It is concluded that atmospheric deposition of nitrogen and acidity has decreased the $\mathrm{pH}$ and $\mathrm{C} / \mathrm{N}$ ratios in $\mathrm{O}_{\mathrm{H}}$ horizons and probably leveled out any former differences. Temperature increased NNM without any changes in microbial status if soil samples are exposed to the prevailing temperature range. At highest soil temperature the microbial biomass decreased significantly at all stands. A low $C_{m i c} / C_{\text {org }}$ ratio at $20^{\circ} \mathrm{C}$ indicated that the resource availability has been restricted. Despite significant changes in microbial status at $20^{\circ} \mathrm{C}$ the NNM was not significantly affected. 


\section{Carbon and nutrient status of beech seedlings grown on the forest floors treated by labelled $\mathbf{N}$}

\subsection{Introduction}

Changing environmental factors such as increasing nitrogen deposition due to elevated atmospheric $\mathrm{N}$-inputs may modify carbon and nutrients dynamics and partitioning in trees. Various studies have reported forest responses to $\mathrm{N}$ deposition ranging from changes in plant tissue chemistry, increased tree growth, and small $\mathrm{N}$ exports to tree tissue, nutrient imbalances, growth declines, and large nitrate exports to drainage water (e.g., Aber et al. 1993; Kahl et al. 1993; Nilsson and Wiklund 1994; Boxman et al. 1995; Bredemeier et al. 1995; Gundersen and Rasmussen 1995; Wright and Tietema 1995; Wright et al. 1995). Descriptive information on $\mathrm{C}$ and $\mathrm{N}$ allocation in differtent tree species under changing environmental conditions is widely available (Canham et al. 1996), but there are little quantitative knowledge of allocation patterns and their changes in seedlings. To examine these patterns and changes it is necessary to study the uptake of labelled nutrients in order to differentiate between external and tree internal nutrient sources (Vivin and Guehl 1997). Much is known about the influence of external nitrogen availability on growth (Canham et al. 1996), however in trees, especially deciduous species, growth depends not only on current $\mathrm{N}$ uptake, but also on internal N stocks (Millard 1996). Tree internal N status may affect not only total growth rate (Millard and Proe 1993), but also the internal partitioning of C and $\mathrm{N}$ uptake. Information on the impact of $\mathrm{N}$ deposition in the form of $\mathrm{N}$ fertilizer on $\mathrm{C}, \mathrm{N}$ and nutrient cations and anions uptake and partitioning is necessary to understand and predict seedlings growth and development under local environmental conditions. The application and recovery of labelled nitrogen tracers in forests has proven to be a powerful tool for gaining insight into $\mathrm{N}$ fluxes and transformations in the soils (Davidson et al 1990; Tietema and Wessel 1992) and vegetation (Preston et al 1990). In a few manipulations of $\mathrm{N}$ inputs to forests, ${ }^{15} \mathrm{~N}$ has been added as a tracer to study altered fates and redistributions of $\mathrm{NH}_{4}{ }^{+}$and $\mathrm{NO}_{3}{ }^{-}$at the ecosystem level (Nadelhoffer and fry 1994; Nadelhoffer et al 1995 and 1999; Tietema et al 1998). To quantify the fate of ammonium-N and nitrate-N immobilization in beech seedlings a ${ }^{15} \mathrm{~N}$ tracer experiment was conducted in which ${ }^{15} \mathrm{NH}_{4}$ and ${ }^{15} \mathrm{NO}_{3}$ were applied separately for two successive growing seasons in throughfall of the pot cultured seedlings grown on the forest floors of the beech, spruce and mixed beech-spruce stands in a green house conditions. Tracing the two $\mathrm{N}$ mineral forms within the ecosystem is 
advantageous because the system's natural $\mathrm{N}$ level is relatively unaltered. In addition, labelling throughfall with either ${ }^{15} \mathrm{~N}$-ammonium or ${ }^{15} \mathrm{~N}$-nitrate enabled us i) to follow the partitioning and retention of added ${ }^{15} \mathrm{~N}$ in above- and below-ground biomass of beech seedlings over two successive growing seasons. ii) to identify major sinks within the plants for both $\mathrm{N}$ forms and the role of the mycorhizal fine roots in nitrogen immobilization. iii) to quantify the internal carbon and other nutrient elements in the beech seedlings affected by nitrogen depositon which enable us to predict the impact of environmental stresses on the plants. 


\subsection{Materials and Methods}

\subsubsection{Study site}

The Study site is located at the Solling forest about 70 to $80 \mathrm{~km}$ southward Hannover, Lower Saxony, Germany $\left(51^{\circ} 47^{\prime} \mathrm{N}\right.$ and $\left.9^{\circ} 37^{\prime} \mathrm{E}\right)$ on slightly inclined $\left(2-4^{\circ}\right)$ slopes. The area is situated at $500 \mathrm{~m}$ elevation a.s.l. with a mean annual air temperature of $6.5^{\circ} \mathrm{C}$ and an annual precipitation of $1050 \mathrm{~mm}$. The temperatures range from an average of $14^{\circ} \mathrm{C}$ in July to $-2^{\circ} \mathrm{C}$ in January. The dominant soil type are podsolic, slightly pseudogleyic Dystric Cambisol (FAO) developed on triassic sandstone covered by a layer of loess with a thickness varying from 0.2 to $2 \mathrm{~m}$ (average $80 \mathrm{~cm}$ ). Soil texture is dominated by silty loam. Morphological humus forms are typical moder. Three adjacent stands (area of each $\approx 400 \mathrm{~m}^{2}$ ) were chosen for the study: a mature (100-120 years) Norway spruce (Picea abies L.karst.) stand partly covered by grass, a 100-120-yr-old beech (Fagus sylvatica L.) stand and a mixed spruce-beech stand covered by 100 to 120 years old trees. A surface application of $2.3 \mathrm{t}$ dolomite $\mathrm{ha}^{-1}$ to Norway spruce stand was registered at 1989.

\subsubsection{Soil sampling and experimental design}

In August 2001, 120 intact soil columns were taken randomly from each stand $(n=40)$ using PVC cylinders (pots) $(15.2 \mathrm{~cm}$ diameter $\times 19 \mathrm{~cm}$ depth). All samples were transferred to a green house partitioned into 4 wagons (diameters $250 \times 92 \times 26 \mathrm{~cm}$ ) with 10 replicates from forest floor samples of each stand at each one. The leachate from each sample passed through a $10 \mathrm{~cm}$ quartz sand in a PVC cylinder set at the bottom of each pot, conducted the leachates through a silicon tube to a brown glass bottle. A cooling system was installed, circulating cool liquid permanently through a flexible tube spiralled four times around each pot to hold the temperature of the samples constant. The sides and the bottom of each wagon was isolated with a $4 \mathrm{~cm}$ thick Styropor. The empty space between the pots at each wagon fill with insulator materials to avoid the waste of temperature. The air and soil temperature were continuously recorded at $5 \mathrm{~cm}$ on top of the forest floor samples and at $3 \mathrm{~cm}$ depth. The samples were artificially irrigated every two days using a bore hole PVC cap ( $5 \mathrm{~cm}$ height) contained small nylon threads which came through the fine holes. The applied amounts of cations, anions and heavy metals were calculated on the basis of the long-term annual input at the study area (Matzner, 1989). The element concentrations in the throughfall solution were constant during the experiment. The leachates volume of the soil solutions were collected in 4 
weeks intervals and stored at $4{ }^{\circ} \mathrm{C}$ until further processing. The application of throughfall and the sampling of leachates as well as the recording of temperature started from September 2001.

\subsubsection{Treatments}

Some $6-8$ beech seeds were planted in half of the pots $(n=60)$ in depth of $0.5 \mathrm{~cm}$ in the last week of August 2001, which germinated after 3 weeks. The control plants and non-plants treatments, each with 18 replicates, received no nitrogen by throughfall. In the tracer treatments $(n=84)$, plants and non-plants samples were supplied either with $1.17 \mathrm{mg} \mathrm{NO}-\mathrm{N}$ $\mathrm{L}^{-1}$ as $\mathrm{NH}_{4}{ }^{15} \mathrm{NO}_{3}$ in irrigated water $(n=42)$, or with $1.18 \mathrm{mg} \mathrm{NH}-\mathrm{N} \mathrm{L}^{-1}$ as ${ }^{15} \mathrm{NH}_{4} \mathrm{NO}_{3}$ by irrigation $(n=42)$ for 442 days. The total amount of nitrogen applied in fertilized plants and non-plants treatments over the course of the experiment accounted for $1.92 \mathrm{~g} \mathrm{~N} \mathrm{~m}^{-2}$ and the total throughfall volume added up to $816 \mathrm{~mm}$.

\subsubsection{Seedlings biomass sampling and analyses}

Seed leaves and the leaf litter samples of the first vegetation period were taken from the shoot tips 3 months after bud break at December 2001. Leaf litter samples of the second vegetation year were collected at November and the whole seedlings were harvested in December 2002. Plant compartments were divided into seed leaves, leaf litter of the first and second growing seasons, stem, coarse roots $(\geq 3 \mathrm{~mm}$ diameter) and fine roots $(<3 \mathrm{~mm}$ diameter) which involved those in the forest floor containing mycorrhizal and non mycorrhizal root tips and the new fine roots grew in sand layer beneath them. The root system partitioned by size and depth in order to represent some trends in biomass, nutrient concentrations and ${ }^{15} \mathrm{~N}$ distribution between the below-ground biomass compartments. Roots were separated from the forest floor by washing and sieving method for several times. The mycorrhizal and non mycorrhizal root tips from each sample were essentially collected from the fine roots developed in forest floors and divided into three replicate samples before ${ }^{15} \mathrm{~N}$ analyzes. All tree biomass compartments were dried at $65^{\circ} \mathrm{C}$ for $96 \mathrm{~h}$, milled, homogenized and weighed before $\mathrm{N}$ content and ${ }^{15} \mathrm{~N}$ analyzes. Stems and coarse roots were milled in a planetary mill (Retsch, Hann, Germany), the other plant components ground in a piston-action ball mill. The mineral nutrients $\mathrm{P}, \mathrm{S}, \mathrm{K}, \mathrm{Ca}, \mathrm{Mg}$, and $\mathrm{Mn}$ in plant compartments were analysed by ICP-AES (Spectro Analytical Instruments, Kleve, Germany) after pressure digestion in 65\% concentrated $\mathrm{HNO}_{3}$. Carbon, Nitrogen and nutrient cations and anions concentrations were calculated on a mass basis and are expressed as a percentage of dry mass. The biomass 
content of each compartment was measured on a mass basis per seedling and the nutrient uptake from soil expressed as mg nutrient per square meter.

\subsection{5 ${ }^{15} \mathrm{~N}$ mass measurements}

The ${ }^{14} \mathrm{~N} /{ }^{15} \mathrm{~N}$ isotope measurements were made with an isotope ratio mass spectrometer (Delta Plus, Finnigan Mat GmbH, Bremen, Germany) coupled to an elemental analyzer (EA 1108, Fisons, Rodano, Milan, Italy) in online mode. ${ }^{15} \mathrm{~N}$ abundance is expressed in atom percent by the ratio:

$$
\text { Atom } \%{ }^{15} \mathrm{~N}=\frac{{ }^{15} N}{{ }^{14} N+{ }^{15} N} \times 100
$$

Values of ${ }^{15} \mathrm{~N}$ enrichment (atom $\%{ }^{15} \mathrm{~N}$ excess) were calculated by subtracting ${ }^{15} \mathrm{~N}$ values from ${ }^{15} \mathrm{~N}$ natural abundance of the control. For determination of ${ }^{15} \mathrm{~N}$ concentrations of soil and plant materials total $\mathrm{N}$ content and the biomass of the respective parts were taken into consideration.

Total ${ }^{15} \mathrm{~N}$ content $=\left({ }^{15} N t-{ }^{15} N c\right) \times[N] \times$ plant biomass

Where ${ }^{15} \mathrm{~N}_{\mathrm{t}}$ and ${ }^{15} \mathrm{~N}_{\mathrm{c}}$ are the atom \% concentrations of ${ }^{15} \mathrm{~N}$ in treated and control plants, respectively, $[\mathrm{N}]$ is the total $\mathrm{N}$ concentration (of a $\mathrm{g}$ dry weight) of plant compartment. For estimation of ${ }^{15} \mathrm{~N}$ uptake per plant, the ${ }^{15} \mathrm{~N}$ concentration of above and below ground parts were summed up. 


\subsubsection{Soil chemical characteristics}

The average forest floor depth including the thin $A_{h}$ layer underneath ranged from 6.67 to 6.36 $\mathrm{cm}$ in control and ${ }^{15} \mathrm{~N}$-fertilized plants treatments. All forest floors were acidic with $\mathrm{pH}_{(\mathrm{H} 2 \mathrm{O})}$ ranging from 3.69 to 3.71 in control and ${ }^{15} \mathrm{~N}$-fertilized plants treatments, respectively. The concentration of organic carbon varied between 172 and $159 \mathrm{~g} \mathrm{~kg}^{-1}$, while the total nitrogen concentration of the forest floors comprised 8.83 and $8.08 \mathrm{~g} \mathrm{~kg}^{-1}$ in control and ${ }^{15} \mathrm{~N}$-fertilized plants treatments, respectively. The $\mathrm{C}: \mathrm{N}$ values of the forest floors ranged from 19.2 to 20.1 in the control and ${ }^{15} \mathrm{~N}$-fertilized plants treatments (Table 1). The average concentrations of the nutrient elements $\mathrm{P}, \mathrm{S}, \mathrm{Na}, \mathrm{K}, \mathrm{Ca}, \mathrm{Mg}, \mathrm{Mn}, \mathrm{Fe}$ and $\mathrm{Al}$ in the forest floors of both treatments under plants has been shown in Table 2.

Table 1. Mean characteristics of the forest floors including the thin $A_{h}$ layer $(\sim 1.5 \mathrm{~cm})$ underneath in the control $(n=18)$ and ${ }^{15} \mathrm{~N}$-fertlized $(n=42)$ plants treatments. (Standard deviation represent in parentheses).

\begin{tabular}{lcccccccc}
\hline treatment & depth & mass & \multicolumn{2}{c}{$\mathrm{pH}$} & & $\mathrm{C}_{\text {org }}$ & $\mathrm{N}_{\text {tot }}$ & $\mathrm{C} / \mathrm{N}$ \\
& $(\mathrm{cm})$ & $\left(\mathrm{Mg} \mathrm{ha}^{-1}\right)$ & $\left(\mathrm{H}_{2} \mathrm{O}\right)$ & $(\mathrm{KCl})$ & & \multicolumn{2}{c}{$\left(\mathrm{g} \mathrm{kg}^{-1}\right)$} & \\
\hline control+plants & 6.67 & 242 & 3.69 & 2.98 & 172 & 8.83 & 19.2 \\
& $(0.83)$ & $(76.0)$ & $(0.34)$ & $(0.43)$ & $(60.8)$ & $(2.71)$ & $(1.63)$ \\
& 6.36 & 231 & 3.71 & 3.02 & 159 & 8.08 & 20.1 \\
& $(1.18)$ & $(74.8)$ & $(0.38)$ & $(0.39)$ & $(58.2)$ & $(2.60)$ & $(1.87)$ \\
\hline
\end{tabular}

Table 2. Mean element concentration of the forest floors $\left(\mathrm{O}_{\mathrm{F}}+\mathrm{O}_{\mathrm{H}}\right)$ including the thin $\mathrm{A}_{\mathrm{h}}$ layer $(\sim 1.5 \mathrm{~cm})$ underneath in the control $(n=18)$ and ${ }^{15} \mathrm{~N}$-fertilized $(n=42)$ plants treatments, analyzed by the $\mathrm{HNO}_{3}$ pressure digestion method. (Standard deviation represent in parentheses).

\begin{tabular}{lccccccccc}
\hline treatment & \multicolumn{10}{c}{ nutrient concentration (\%) } \\
\cline { 2 - 10 } & $\mathrm{P}$ & $\mathrm{S}$ & $\mathrm{Na}$ & $\mathrm{K}$ & $\mathrm{Ca}$ & $\mathrm{Mg}$ & $\mathrm{Mn}$ & $\mathrm{Fe}$ & $\mathrm{Al}$ \\
\hline control+plants & 0.068 & 0.103 & 0.024 & 0.456 & 0.191 & 0.157 & 0.025 & 1.157 & 1.872 \\
& $(0.012)$ & $(0.032)$ & $(0.000)$ & $(0.154)$ & $(0.106)$ & $(0.043)$ & $(0.010)$ & $(0.239)$ & $(0.502)$ \\
\hline${ }^{15} \mathrm{~N}$-fertilized+plants & 0.070 & 0.096 & 0.028 & 0.525 & 0.217 & 0.180 & 0.029 & 1.259 & 2.096 \\
& $(0.015)$ & $(0.033)$ & $(0.001)$ & $(0.179)$ & $(0.116)$ & $(0.048)$ & $(0.013)$ & $(0.263)$ & $(0.515)$ \\
\hline
\end{tabular}




\subsubsection{Water balances}

The tendency in water fluxes and balances from plants and non-plants samples has been shown in Figure 2. The total precipitation over the course of experiment accounted for $816 \mathrm{~mm}$, equal $1.86 \mathrm{~mm}$ per day. In the first small growing season and over the autumn and winter 2001, the water fluxes kept close by plants and non-plants, while in the next growing season the flux rates of water demonstrated a clear difference between the plants and non-plants as the consequence of the higher water demand and consumption by plants. The difference on water balances between the plants and non-plants samples became maximum in the period of high demand from June to October of the second vegetation year (261 to 375 days after first irrigation) which conformed with elevated air temperatures (Figure 1), however the differences were not statistically significant. The total volume of water fluxes from plants and non-plants treatments at the end of the experiment comprised 536 to $627 \mathrm{~mm}$, respectively. Comparing the total values of transpired water over the entire experiment in non-plants samples accounted for $189 \mathrm{~mm}$, while in plants samples the values added up to $280 \mathrm{~mm}$.

Figure 1. Mean air and forest floors temperatures $\left({ }^{\circ} \mathrm{C}\right)$ during the experiment time.

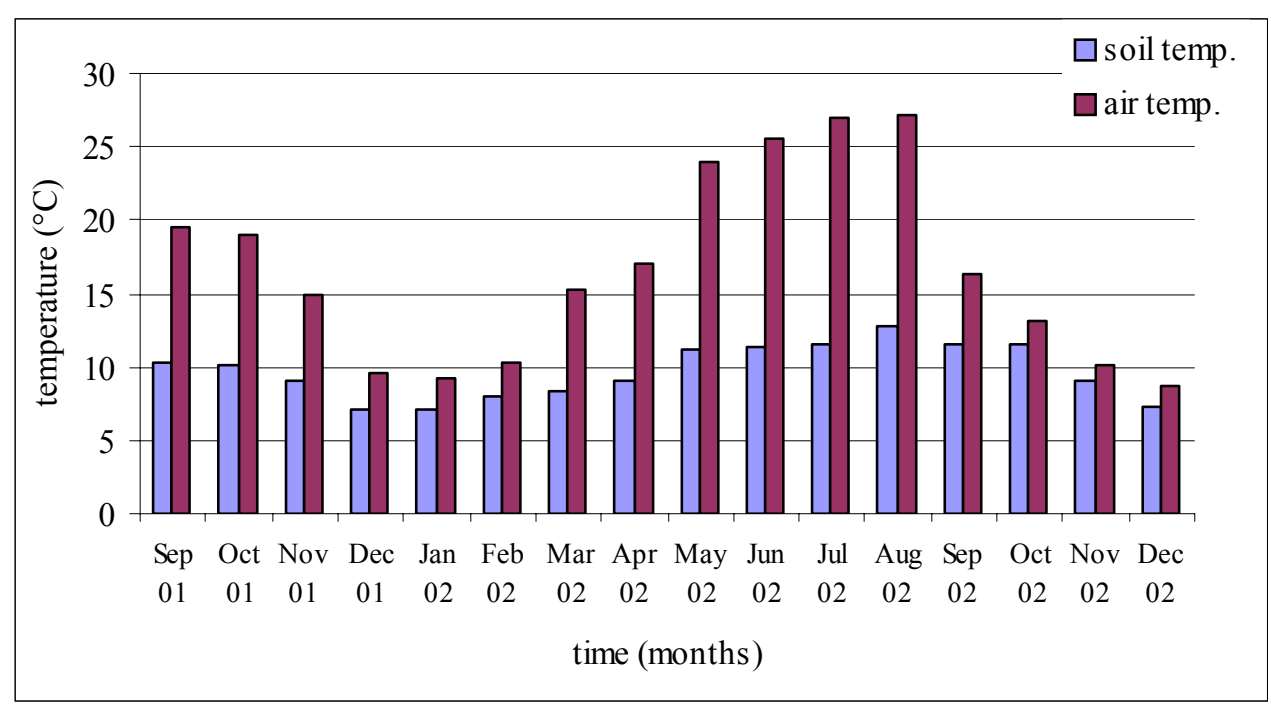


Figure 2. Average water fluxes and water balances for non-plants $(n=60)$ and plants samples $(n=60)$ of both control and ${ }^{15} \mathrm{~N}$-fertilized treatments in intervals between samplings.
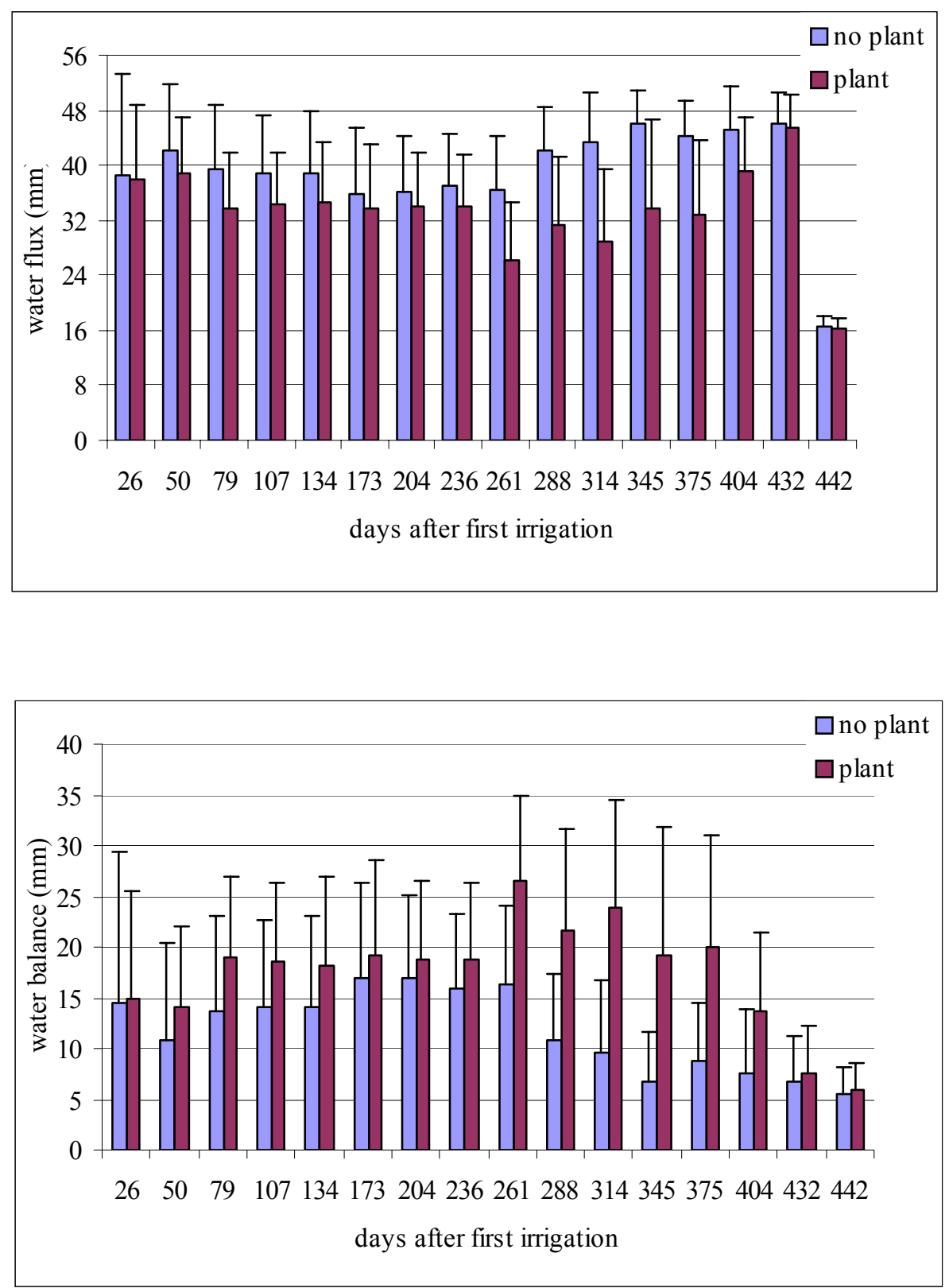

\subsubsection{Statistical analyses}

The Mann-Whitney U-Test at $p<0.05$ level, was used to evaluate the significance of differences between the treatments in individual plant compartments, performed by the program Statistica version 6.0. 


\subsection{Results and Discussion}

\subsubsection{Above- and below-ground plant biomass}

The growth of the seedlings in the first growing season is mainly determined by reserved nutrient stocks of the seeds (Suner and Röhrig, 1980). In the present study seeds with $357 \mathrm{mg}$ dry weight biomass comprised 28.6 - 30.7 \% of the total seedling biomass (Table 3). Schmaltz (1966) found that about $20 \%$ of the dry weight biomass of one year old beech seedling depends on the assimilation efficiency of the seed leaves and some $40 \%$ depends on the assimilation efficiency and mobilization of nutrient reserve stocks in the seeds. In comparison to original biomass of seeds, stems with $495-454 \mathrm{mg}$ biomass per plant in the control and ${ }^{15} \mathrm{~N}$ fertilized treatments accounted for $39.7-39.0 \%$ of the total seedling biomass. Other major biomass fractions were coarse roots $(310-238 \mathrm{mg})$, leaf litter of the second vegetation period (139 - $157 \mathrm{mg})$, leaf litter of the first growing season $(89.1-106 \mathrm{mg})$, new fine roots grew in sand layer (77.6 - 66.6 mg), seed leaves $(74.4$ - $79.7 \mathrm{mg})$, buds $(69.4$ - $73.2 \mathrm{mg})$ and forest floor fine roots $(55.6-55.5 \mathrm{mg})$, respectively. Total seedling biomass ranged from $1248 \mathrm{mg}$ at the control to $1163 \mathrm{mg}$ at ${ }^{15} \mathrm{~N}$-fertilized treatment (Table 3). The total biomass content of the above-ground compartments ranged from $805 \mathrm{mg}$ at the control to $803 \mathrm{mg}$ at ${ }^{15} \mathrm{~N}$-fertilized treatment, indicated no significant differences between the same above-ground compartments of the seedlings in both treatments. The amounts of below-ground biomass varied between 443 and $360 \mathrm{mg}$ by control and ${ }^{15} \mathrm{~N}$-fertilized treatments, respectively. Analyses of variance $(P<$ 0.05) revealed no significant differences on biomass content of the fine roots system between the control and ${ }^{15} \mathrm{~N}$-fertilized treatments, while the biomass content of the coarse roots were significantly decreased at ${ }^{15} \mathrm{~N}$-fertilized treatment. Shoot weight ratio (SWR) accounted for 64.4 to $68.7 \%$, while root weight ratio (RWR) contributed to $35.6-31.3 \%$ of the total seedling biomass between the control and ${ }^{15} \mathrm{~N}$-fertilized treatments. Nitrogen fertilizer affected the beech seedlings by stimulating growth and reducing biomass allocation to the roots. Such a growth increase and shift in biomass allocation from roots to shoots is commonly associated with increased nitrogen availability (Cannell 1985, Evans 1989). Johnson et al., (1997) studied the effect of three light treatments on European beech seedlings under full sun, gap and understory in organic and mineral soils found a shoot weight ratio ranged from $55-53 \%$ in understory and full sun versus $45-57 \%$ root weight ratio. Dhrenbush (1990) and VanHess (1997) found the below-ground biomass distribution in seedlings and small saplings of pedunculate oak and beech comprised $45-65 \%$ of the total biomass, respectively. The results 
of the present study are in magnitude in consistant with Ljungström and Stjernquist (1995) who found the total biomass of beech seedlings after one growing season in the range of 353 to $529 \mathrm{mg}$ and in the second year a total dry weight biomass of 614 to $2746 \mathrm{mg}$. Glatzel and Kazda (1985) found a dry weight biomass of about 1800 and $2400 \mathrm{mg}$ respectively in pot cultured beech seedlings transplanted from the field in the autumn of their first season and harvested in the autumn of the following year. Minotta and Pinzauti (1996) found a total beech seedlings biomass ranged from $0.56 \mathrm{~g}$ at low fertility soils under low light conditions to $2.84 \mathrm{~g}$ at high fertility under high light conditions. To a large extent, Van Hees and Clerkx (2003) found a dry weight biomass of the beech saplings in the range of $407 \mathrm{~g}$ in shaded to $649 \mathrm{~g}$ at full light and the average percentage of the below-ground biomass of 41 to $50 \%$ for shaded and non-shaded beech. The ratio of root-to-shoot at the end of the second growing season increased by reference plants at the control in compare to ${ }^{15} \mathrm{~N}$ treated plants, varied between 0.63 and $0.53 \mathrm{mg} \mathrm{mg}^{-1}$. The observed difference in balance between root-to-shoot ratio are in agreement with the review by Skärby et al (1998), where increased retention of carbon in the leaf litter of the seedlings at ${ }^{15} \mathrm{~N}$-fertilized treatment, decreased allocation of carbon to roots system, leads to decreased pools of carbohydrates in roots, resulting in a lower root-to-shoot ratio. In addition, the reduced values of root-to-shoot biomass ratios with $\mathrm{N}$ fertilization in compare to reference plants in the present study can be attributed to increased nutrients sink activity in shoot compartments and a shift in the functional balance between carbon and nutrient acquisition and biomass distribution by above- and below-ground plant compartments. The reduced values of root-to-shoot ratios with $\mathrm{N}$ fertilization found in the present study are also in consistent with those of other studies on seedlings and small saplings (e.g. Cromer and Jarvis 1990; Canham et al., 1996; Xu and Timmer 1999). To investigate the effects of environmental conditions on biomass distribution between the above- and below-ground compartments, Minotta and Pinzauti (1996) compared a root-to-shoot ratio in beech seedlings under low, intermediate and high light conditions in soils with high and low fertility, the detected values were in the range of $0.82-0.75 \mathrm{~g} \mathrm{~g}^{-1}$ at low, $0.85-0.95 \mathrm{~g} \mathrm{~g}^{-1}$ at intermediate and $0.98-1.35 \mathrm{~g} \mathrm{~g}^{-1}$ at high light environment, in high and low fertility conditions, respectively. To a large extent, Van Hees and Clerkx (2003) investigated the effect of light conditions on the root-to-shoot ratios of silver birch, pedunculate oak and beech saplings, observed that under shaded conditions the values were in the range of $0.34,0.62$ and $0.68 \mathrm{~g} \mathrm{~g}^{-1}$, while under full light conditions the ratios for the above mentioned species were $0.48,0.84$ and $1.01 \mathrm{~g} \mathrm{~g}^{-1}$, respectively. 
Table 3. Total biomass content per seedling (g) and percentage of the biomass of seeds, above- and below-ground compartments to total seedlings biomass and the root-to-shoot ratio at the end of the second growing season in control $(n=18)$ and ${ }^{15} \mathrm{~N}$-fertilized treatments $(n=$ 42), (Standard deviation represent in parentheses).

\begin{tabular}{lcccc}
\hline \multirow{2}{*}{ pool } & \multicolumn{4}{c}{ biomass } \\
\cline { 2 - 5 } & \multicolumn{2}{c}{ control } & ${ }^{15} \mathrm{~N}$-fertilized \\
\hline seeds & 357 & 28.6 & 357 & 30.7 \\
& & & & \\
seed leaves & $74.4(15.4)$ & 5.96 & $79.7(23.8)$ & 6.85 \\
buds & $69.4(26.0)$ & 5.57 & $73.2(39.2)$ & 6.29 \\
leaf litter (1 ${ }^{\text {st }}$ season) & $89.1(46.0)$ & 7.14 & $106(45.2)$ & 9.13 \\
leaf litter (2 ${ }^{\text {nd }}$ season) & $139(113)$ & 11.1 & $157(75.5)$ & 13.5 \\
stems & $495(172)$ & 39.7 & $454(23.6)$ & 39.0 \\
above-ground (total) $(\mathrm{SWR})$ & $805(265)$ & 64.4 & $803(310)$ & 68.7 \\
coarse roots & $310(116)$ & 24.8 & $238(112)$ & 20.5 \\
forest floor fine roots & $55.6(36.1)$ & 4.46 & $55.5(27.5)$ & 4.77 \\
fine roots in sand layer & $77.6(38.4)$ & 6.22 & $66.6(45.5)$ & 5.73 \\
below ground (total) $(\mathrm{RWR})$ & $443(150)$ & 35.6 & $360(136)$ & 31.3 \\
plant (total) & $1248(385)$ & 100 & $1163(427)$ & 100 \\
& & & & \\
root-to-shoot (mg mg $\left.{ }^{-1}\right)$ & 0.63 & & 0.53 & \\
\hline
\end{tabular}

\subsubsection{Carbon and nutrient concentrations in plants}

Elemental concentrations have often been used to describe the nutritional status and nutrient requirements of plants (Ingestad 1979, Marschner 1986). In comparison to above- and belowground compartments seeds contained the largest pool of nutrients reserves for the growth of the seedlings (Table 4). In seedlings the partitioning of total carbon concentration in the aboveground compartments varied between $48.7-48.5 \%$ in stems, $47.6-48.1 \%$ and $44.2-44.7$ $\%$ in the leaf litter of the second and first growing seasons, $47.2-46.9 \%$ in seed leaves and $45.2-45.6 \%$ in buds. The concentration of carbon in below-ground compartments varied between $49.4-49.5 \%$ and $46.1-46.5 \%$ in fine roots grew in forest floor and in sand layer 
and allocated to $47.4-47.3 \%$ in coarse roots at the control and ${ }^{15} \mathrm{~N}$-fertilized treatments, respectively. There were no major differences in $\mathrm{C}$ concentration between the different seedlings compartments as would be expected, since $\mathrm{C}$ constitutes about half of the plant biomass (Runion et al., 1999). Seed leaves indicated the largest pool of nitrogen concentration $(2.02-1.77 \%)$ between the above-ground compartments, followed by buds $(1.17-1.14 \%)$, stems $(1.12-1.21 \%)$ and the leaf litter of the first and second vegetation periods $(0.88-0.94$ $\%)$ to $(0.73-0.69 \%)$, respectively. In below-ground compartments fine roots system in consistent with their physiological activity and protein storage (Landsberg and Gower, 1997), exhibited the second largest $\mathrm{N}$ concentrations pool in seedlings. The new fine roots grew in sand layer contained the largest values of $\mathrm{N}$ concentration $(1.70-1.45 \%)$ compared to forest floor fine roots $(1.57-1.46 \%)$ and coarse roots $(1.44-1.32 \%)$ at the control and ${ }^{15} \mathrm{~N}$ fertilized treatments, respectively. The concentrations of either carbon or nitrogen in each plant compartment were not significantly altered between the control and ${ }^{15} \mathrm{~N}$ treated plants. The concentration values of nutrient cations and anions in most above-ground compartments were greatest for $\mathrm{Ca}$ followed by $\mathrm{K}, \mathrm{Mg}, \mathrm{Mn}, \mathrm{S}$ and $\mathrm{P}$ in both treatments. In above-ground compartments the largest concentrations of $\mathrm{Ca}(1.29-1.23 \%)$ and $\mathrm{Mn}(0.52-0.48 \%)$, were observed in the leaf litter of the first vegetation period. The largest concentrations of $\mathrm{S}(0.17-$ $0.19 \%), \mathrm{K}(0.72-0.49 \%)$ and $\mathrm{Mg}(0.38-0.36 \%)$ were detected in seed leaves, while the largest concentrations for $\mathrm{P}(0.13-0.13 \%)$ was found in the buds of the beech seedlings (Table 4 and 5). In below-ground compartments the highest concentrations were observed for $\mathrm{K}$ followed by $\mathrm{Ca}, \mathrm{P}, \mathrm{S}, \mathrm{Mg}$ and $\mathrm{Mn}$, respectively. Coarse roots contained the largest concentrations of $\mathrm{Ca}(0.20-0.19 \%), \mathrm{Mg}(0.10-0.10 \%)$ and $\mathrm{Mn}(0.08-0.08 \%)$, while new fine roots grew in sand layer were detected as the largest pool for P $(0.13-0.12 \%)$, S $(0.16-$ $0.13 \%)$ and $\mathrm{K}(0.48-0.44 \%)$ concentrations between the below-ground compartments of the beech seedlings (Table 4 and 5). Analyses of variance $(p<0.05)$ revealed no significant effect of ${ }^{15} \mathrm{~N}$-fertilizer on concentration of each nutrient cation or anion in the same compartments of the plants between the treatments. The concentration of carbon, nitrogen and other nutrient elements were not influenced by type of substrate. Analyses of variance $(p<0.05)$ indicated no significant effect of the forest floor under beech, spruce and mixed species stands on concentration of total carbon and nutrient elements in above- and below-ground compartments of the beech seedlings between the treatments. In comparison to literature, total concentrations of N, P, S and nutrient cations in stems and roots of the seedlings in both treatments were in magnitude in contrast with the values observed by Ljungström and Stjernquist (1995) for beech seedlings harvested in September, while the foliage litter concentrations of total N, P, K and Ca 
were lower, the values for $\mathrm{S}$ and $\mathrm{Mg}$ were in the same level and the concentration of Mn which reflects the local site conditions were observed to be higher than foliage concentrations reported by above mentioned authors. In comparison to other plant compartments the leaf litter total nitrogen and phosphorus concentrations decreased significantly in autumn of the first and second vegetation year in both treatments. A decrease in the leaf litter mobile nutrients $\mathrm{N}, \mathrm{P}, \mathrm{S}$ and $\mathrm{K}$ can be related to nutrients retranslocation processes over the senescence period from leaves to storage organs due to dilution effect. Luxmoore et al. (1981) and Tyrrell and Boerner (1987) attributed a decrease in absolute amounts of elements in the leaves during the senescence period to resumption of these nutrients from the leaves towards perennial tissues. The $\mathrm{N}$ senescence could result from increased transport of leaf-derived $\mathrm{N}$ to woody storage tissues such as stems as observed also for adult beech trees (Geßler et al., 1998) and in roots which also contribute to N storage in young broad leaf trees (Tromp, 1983; Suzuki and Kohno, 1983; Millard and Proe, 1991). A similar trend in nutrient depletion was also observed in the foliage $\mathrm{K}$ concentration, although the differences between the concentration of $\mathrm{K}$ in the foliage and stems were not statistically different. However, comparison based on concentrations alone is not a sound basis for estimating retranslocation of nutrients (Nambiar and Fife,1991). Confirmative evidence was obtained by comparing changes in $\mathrm{Ca} / \mathrm{N}$ and $\mathrm{Ca} / \mathrm{P}$ ratios. Because $\mathrm{Ca}$ is immobile in live tissues, its ratio with $\mathrm{N}$ and $\mathrm{P}$ would reflect the loss in tissue mass likely to have occurred during leaf senescence (Nambiar and Fife, 1991). In the present study the ratios of $\mathrm{Ca} / \mathrm{N}$ in the senesced foliage of the second season comprised $1.43-1.37$ compared to corresponding values of $0.36-0.36$ and $0.15-0.13$ for stems and coarse roots. Similarly, $\mathrm{Ca} / \mathrm{P}$ ratios accounted for $28.2-24.5$ in senesced foliage of the second season, compared to $4.42-$ 4.68 for stems and $1.74-1.57$ for coarse roots, between the control and ${ }^{15} \mathrm{~N}$-fertilized treatments, respectively. The results of the $\mathrm{Ca} / \mathrm{N}$ and $\mathrm{Ca} / \mathrm{P}$ ratios indicated more allocation of retranslocated nitrogen and phosphorus from foliage litter at the end of the season mainly to coarse roots. In comparison to other plant compartments no depletion effect were detected from the leaf litter concentrations of $\mathrm{S}$ as well as mainly immobile elements $\mathrm{Ca}, \mathrm{Mg}$ and $\mathrm{Mn}$. The large concentrations of foliage $\mathrm{Mn}$ in beech seedlings have also been reported by Glatzel and Kazda (1985) and in silver fir seedlings by Szymura (2003), as well as in beech trees by Zech et al. (1985). Higher leaf litter concentration of manganese in the present study has been moderated by the larger presence of calcium and magnesium in leaves, which may confirm a protective function of $\mathrm{Ca}$ and $\mathrm{Mg}$ for heavy metal toxicity in the foliage components. 
Table 4. Nutrients concentrations ( $\% \mathrm{DW})$ in seeds, above- and below-ground compartments of the beech seedlings in control treatment $(n=18)$, (Standard deviation represent in parentheses).

\begin{tabular}{|c|c|c|c|c|c|c|c|c|}
\hline control treatment & & & & trient col & centratio & $(\%)$ & & \\
\hline pool & $\mathrm{C}$ & $\mathrm{N}$ & $\mathrm{P}$ & $\mathrm{S}$ & $\mathrm{K}$ & $\mathrm{Ca}$ & $\mathrm{Mg}$ & $\mathrm{Mn}$ \\
\hline seeds & 57.3 & 3.13 & 0.259 & 0.182 & 0.719 & 0.603 & 0.176 & 0.156 \\
\hline & $(0.14)$ & $(0.43)$ & $(0.017)$ & $(0.012)$ & $(0.033)$ & $(0.030)$ & $(0.005)$ & $(0.007)$ \\
\hline buds & 45.2 & 1.17 & 0.130 & 0.090 & 0.428 & 0.542 & 0.110 & 0.207 \\
\hline & $(0.97)$ & $(0.14)$ & $(0.016)$ & $(0.008)$ & $(0.040)$ & $(0.052)$ & $(0.028)$ & $(0.071)$ \\
\hline seed leaves & 47.2 & 1.77 & 0.102 & 0.171 & 0.447 & 1.205 & 0.378 & 0.397 \\
\hline leaf litter ( $1^{\text {st }}$ season $)$ & 44.2 & 0.88 & 0.083 & 0.132 & 0.324 & 1.229 & 0.263 & 0.521 \\
\hline & $(1.11)$ & $(0.12)$ & $(0.025)$ & $(0.018)$ & $(0.092)$ & $(0.220)$ & $(0.088)$ & $(0.187)$ \\
\hline leaf litter ( $2^{\text {nd }}$ season $)$ & 47.6 & 0.69 & 0.035 & 0.085 & 0.289 & 0.987 & 0.118 & 0.484 \\
\hline & $(1.46)$ & $(0.06)$ & $(0.011)$ & $(0.010)$ & $(0.108)$ & $(0.253)$ & $(0.112)$ & $(0.221)$ \\
\hline stems & 48.7 & 1.12 & 0.091 & 0.081 & 0.305 & 0.403 & 0.075 & 0.166 \\
\hline & $(0.71)$ & $(0.21)$ & $(0.026)$ & $(0.012)$ & $(0.033)$ & $(0.070)$ & $(0.026)$ & $(0.059)$ \\
\hline coarse roots & 47.4 & 1.32 & 0.117 & 0.092 & 0.405 & 0.203 & 0.097 & 0.083 \\
\hline & $(0.70)$ & $(0.28)$ & $(0.028)$ & $(0.016)$ & $(0.047)$ & $(0.043)$ & $(0.020)$ & $(0.030)$ \\
\hline forest floor fine roots & 49.4 & 1.57 & 0.127 & 0.138 & 0.252 & 0.191 & 0.070 & 0.040 \\
\hline & $(1.21)$ & $(0.20)$ & $(0.029)$ & $(0.028)$ & $(0.094)$ & $(0.067)$ & $(0.039)$ & $(0.016)$ \\
\hline fine roots in sand layer & 46.1 & 1.45 & 0.120 & 0.130 & 0.438 & 0.127 & 0.077 & 0.031 \\
\hline & $(1.98)$ & $(0.26)$ & $(0.031)$ & $(0.023)$ & $(0.092)$ & $(0.051)$ & $(0.022)$ & $(0.006)$ \\
\hline
\end{tabular}


Table 5. Nutrients concentrations (\% DW) in seeds, above- and below-ground compartments of the beech seedlings in ${ }^{15} \mathrm{~N}$-fertilized treatment $(n=42)$, (Standard deviation represent in parentheses).

\begin{tabular}{|c|c|c|c|c|c|c|c|c|}
\hline${ }^{15} \mathrm{~N}$-fertilized treatment & & & & atrient co & centratic & $n(\%)$ & & \\
\hline pool & $\mathrm{C}$ & $\mathrm{N}$ & $\mathrm{P}$ & $\mathrm{S}$ & $\mathrm{K}$ & $\mathrm{Ca}$ & $\mathrm{Mg}$ & $\mathrm{Mn}$ \\
\hline seeds & 57.3 & 3.13 & 0.259 & 0.182 & 0.719 & 0.603 & 0.176 & 0.156 \\
\hline & $(0.14)$ & $(0.43)$ & $(0.017)$ & $(0.012)$ & $(0.033)$ & $(0.030)$ & $(0.005)$ & $(0.007)$ \\
\hline buds & 45.6 & 1.14 & 0.133 & 0.091 & 0.408 & 0.549 & 0.114 & 0.214 \\
\hline & $(0.84)$ & $(0.12)$ & $(0.020)$ & $(0.010)$ & $(0.047)$ & $(0.068)$ & $(0.025)$ & $(0.079)$ \\
\hline seed leaves & 46.9 & 2.02 & 0.135 & 0.188 & 0.492 & 1.154 & 0.357 & 0.381 \\
\hline & $(0.17)$ & $(0.05)$ & $(0.020)$ & $(0.004)$ & $(0.024)$ & $(0.036)$ & $(0.014)$ & $(0.011)$ \\
\hline leaf litter( $1^{\text {st }}$ season $)$ & 44.7 & 0.94 & 0.091 & 0.132 & 0.329 & 1.288 & 0.289 & 0.483 \\
\hline & $(1.13)$ & $(0.16)$ & $(0.036)$ & $(0.018)$ & $(0.096)$ & $(0.336)$ & $(0.108)$ & $(0.207)$ \\
\hline leaf litter ( $2^{\text {nd }}$ season $)$ & 48.1 & 0.73 & 0.041 & 0.091 & 0.303 & 0.999 & 0.131 & 0.483 \\
\hline & $(2.08)$ & $(0.09)$ & $(0.018)$ & $(0.009)$ & $(0.127)$ & $(0.302)$ & $(0.087)$ & $(0.266)$ \\
\hline stems & 48.5 & 1.21 & 0.094 & 0.085 & 0.307 & 0.439 & 0.082 & 0.167 \\
\hline & $(0.75)$ & $(0.17)$ & $(0.026)$ & $(0.012)$ & $(0.036)$ & $(0.107)$ & $(0.030)$ & $(0.057)$ \\
\hline coarse roots & 47.3 & 1.44 & 0.121 & 0.099 & 0.410 & 0.190 & 0.100 & 0.076 \\
\hline & $(0.85)$ & $(0.23)$ & $(0.032)$ & $(0.015)$ & $(0.052)$ & $(0.037)$ & $(0.028)$ & $(0.024)$ \\
\hline forest floor fine roots & 49.5 & 1.46 & 0.115 & 0.129 & 0.227 & 0.239 & 0.069 & 0.036 \\
\hline & $(1.64)$ & $(0.18)$ & $(0.030)$ & $(0.025)$ & $(0.112)$ & $(0.096)$ & $(0.043)$ & $(0.013)$ \\
\hline fine roots in sand layer & 46.5 & 1.70 & 0.131 & 0.158 & 0.475 & 0.206 & 0.095 & 0.034 \\
\hline & $(2.55)$ & $(0.31)$ & $(0.034)$ & $(0.064)$ & $(0.356)$ & $(0.432)$ & $(0.071)$ & $(0.024)$ \\
\hline
\end{tabular}




\subsubsection{Nutients balances in plants}

The assimilated carbon and the nitrogen uptake from forest floor supply by seedlings in the control and ${ }^{15} \mathrm{~N}$-fertilized treatments varied between $148-142 \mathrm{~g} \mathrm{C} \mathrm{m}^{-2}$ and $1.36-1.32 \mathrm{~g} \mathrm{~N} \mathrm{~m}^{-2}$ revealed no significant effect of $\mathrm{N}$ additions on the balance stocks of carbon and nitrogen in beech seedlings between the treatments (Table 6). The difference between nutrients uptake from seed reserves and soil (balance values) accounted for $1.56-1.76 \mathrm{~g} \mathrm{~m}^{-2}$ for Ca, followed by $0.77-0.79 \mathrm{~g} \mathrm{~m}^{-2}$ for $\mathrm{Mn}, 0.69-0.65 \mathrm{~g} \mathrm{~m}^{-2}$ for $\mathrm{K}, 0.31-0.35 \mathrm{~g} \mathrm{~m}^{-2}$ for $\mathrm{Mg}, 0.22-0.24 \mathrm{~g} \mathrm{~m}^{-2}$ for $\mathrm{S}$ and $0.11 \mathrm{~g} \mathrm{~m}^{-2}$ for $\mathrm{P}$ between the control and ${ }^{15} \mathrm{~N}$-fertilized treatments. Total carbon assimilated by seedlings over the two growing seasons in both treatments was 1.94 to 1.86 time greater than the reserved carbon stocks in seeds. In contrast seedlings took up $32.6-31.7 \%$ of the $\mathrm{N}$ demand and $31.8-32.9 \%$ of $\mathrm{P}$ from the forest floor and the rest provided from seed nitrogen and phosphorus supply. This finding indicated that seeds contribute substantially in $\mathrm{N}$ and $\mathrm{P}$ nutrition of the beech seedlings. The percent of net nutrients uptake (balance values) to seed nutrient reserves exhibited an imbalance for Mn (369 - 380\%), Ca (195-219\%) and Mg $(134-149 \%)$, inferring high accumulation of these cations in different compartments of the seedlings, however the lack of established break points precluded distinguishing between luxury or excess consumption of $\mathrm{Mn}, \mathrm{Ca}$ and $\mathrm{Mg}$. The net uptake of sulphur and potassium were $91.3-98.2 \%$ and $71.7-68.1 \%$ of $\mathrm{S}$ and $\mathrm{K}$ concentrations in seeds, respectively. Potassium is largely taken up selectively and activity by plants shortly after seedlings germination (Mengel and kirkby, 1982). 
Table 6. Nutrients uptake of beech seedlings and the ratio of nutrients uptake to nutrients reserves in seeds $(\%)$ in the control $(n=18)$ and ${ }^{15} \mathrm{~N}$-fertilized $(n=42)$ treatments at the end of the experiment, (Standard deviation represent in parentheses).

\begin{tabular}{lcccccccc}
\hline treatment & \multicolumn{8}{c}{ nutrients balance $\left(\mathrm{g} \mathrm{m}^{-2}\right)$} \\
\hline \multirow{3}{*}{ control+plant } & $\mathrm{C}$ & $\mathrm{N}$ & $\mathrm{P}$ & $\mathrm{S}$ & $\mathrm{K}$ & $\mathrm{Ca}$ & $\mathrm{Mg}$ & $\mathrm{Mn}$ \\
\cline { 2 - 9 } & 148.4 & 1.36 & 0.11 & 0.22 & 0.69 & 1.56 & 0.31 & 0.77 \\
& $(1.84)$ & $(0.76)$ & $(0.06)$ & $(0.03)$ & $(0.12)$ & $(0.21)$ & $(0.08)$ & $(0.17)$ \\
${ }^{15} \mathrm{~N}-$ fertilized+plant & 141.8 & 1.32 & 0.11 & 0.24 & 0.65 & 1.76 & 0.35 & 0.79 \\
& $(2.12)$ & $(0.68)$ & $(0.06)$ & $(0.04)$ & $(0.15)$ & $(0.31)$ & $(0.09)$ & $(0.20)$ \\
\hline \multirow{3}{*}{ control+plant } & $\mathrm{C}$ & $\mathrm{N}$ & $\mathrm{P}$ & $\mathrm{S}$ & $\mathrm{K}$ & $\mathrm{Ca}$ & $\mathrm{Mg}$ & $\mathrm{Mn}$ \\
\cline { 2 - 9 } & 194 & 32.6 & 31.8 & 91.3 & 71.7 & 195 & 134 & 369 \\
${ }^{15} \mathrm{~N}$-fertilized+plant & 186 & 31.7 & 32.9 & 98.2 & 68.1 & 219 & 149 & 380 \\
\hline
\end{tabular}

\subsubsection{Impact of ${ }^{15} \mathrm{~N}$-fertilizer on mycorrhizal assimilation}

The number of ectomycorrhizal root tips colonized in forest floor fine roots by ${ }^{15} \mathrm{~N}$ fertilizer application were decreased markedly compared to reference plants in control treatment, exhibited reduced effect of ${ }^{15} \mathrm{~N}$-fertilizer on fungal biomass production by beech seedlings. Fungal biomass of mycorrhizal seedlings have also consistently been reduced at elevated levels of N supply (Nylund and Wallander, 1989; Wallander and Nylund, 1991, 1992; Arnebrant and Söderström, 1992; Termorshuizen and Ket, 1991; Tietema, 1998). In addition, similar values of the tracer excess enriched values in mycorrhizal root tips after ${ }^{15} \mathrm{~N}$ ammonium and ${ }^{15} \mathrm{~N}$-nitrate $(0.30-0.30 \%)$ with corresponding values in non mycorrhizal root tips $(0.35-0.36 \%)$ and the carrier root tips $(0.36-0.37 \%)$ suggest that the assimilated nitrogen through mycorrhiza due to physiologicaly inactive conditions of plants and mycorrhiza fungi during autumn may transit from mycorrhiza into the fine roots system and coarse roots. In consistent, Zeller et al. (2000) reported strongly decrease in difference between ${ }^{15} \mathrm{~N}$ of mycorrhizas in the autumn of each year with that of fine roots, especially after the second year ${ }^{15} \mathrm{~N}$ application, indicating a dilution of soil-derived $\mathrm{N}$ by tree $\mathrm{N}$. In consistent with Wallander and Nylund (1991), it was detected that the amount of carbon in the coarse roots of the seedlings decreased in response to ${ }^{15} \mathrm{~N}$-fertilization compared to control plants. This finding revealed that fungal growth was inhibited by reduced carbon flow from host to 
fungus but can not explain the inhibitory effect of nitrogen application on fungal development at least for reasons other than carbohydrate deficiency (Wallander, 1995).

\subsection{5 ${ }^{15} \mathrm{~N}$ tracer retention and recoveries in plants}

The retention of ${ }^{15} \mathrm{~N}$-ammonium and ${ }^{15} \mathrm{~N}$-nitrate among different compartments of the beech seedlings reflects the relative partitioning of ammonium and nitrate- $\mathrm{N}$ deposition as influenced by physiological processes of the internal nitrogen cycle within the plant. The ${ }^{15} \mathrm{~N}$ partitioning of both ${ }^{15} \mathrm{~N}$ tracers in the beech seedlings followed the same pattern of the total $\mathrm{N}$ distribution (Table 7 ). Among the above-ground compartments stems were the main sink strength for ${ }^{15} \mathrm{~N}$. After 442 days of tracer application between $6.44-5.90 \mathrm{mg} \mathrm{m}{ }^{-2}{ }^{15} \mathrm{~N}$ retained in stems, conformed $0.035-0.041 \mathrm{mg} \mathrm{g}^{-1}$ after ${ }^{15} \mathrm{~N}$-ammonium and ${ }^{15} \mathrm{~N}$-nitrate inputs. Comparing the values of ${ }^{15} \mathrm{~N}$ retained between the leaf litte of the first and second seasons, revealed higher concentrations of tracer in the foliage of the second season $(0.015-$ $\left.0.013 \mathrm{mg} \mathrm{g}^{-1}\right)$ versus the leaf litter of the first season $\left(0.006-0.007 \mathrm{mg} \mathrm{g}^{-1}\right)$, while the conformed absolute values accounted for $0.90-0.69 \mathrm{mg} \mathrm{m}^{-2}$ vs. $0.22-0.24 \mathrm{mg} \mathrm{m}^{-2}$, after ${ }^{15} \mathrm{~N}$ ammonium and ${ }^{15} \mathrm{~N}$-nitrate inputs. The amounts of ${ }^{15} \mathrm{~N}$ retention for the buds ranged from 0.84 to $1.22 \mathrm{mg} \mathrm{m}^{-2}$ which conformed $0.031-0.037 \mathrm{mg} \mathrm{g}^{-1}$ after ${ }^{15} \mathrm{~N}$-ammonium and ${ }^{15} \mathrm{~N}$ nitrate inputs. The least values of ${ }^{15} \mathrm{~N}$ retained in the above-ground compartments were observed in the seed leaves. The amounts of tracers retained in seed leaves accounted for $0.19-0.15 \mathrm{mg} \mathrm{m}^{-2}$ which conformed $0.006-0.006 \mathrm{mg} \mathrm{g}^{-1}$ after ${ }^{15} \mathrm{~N}$-ammonium and ${ }^{15} \mathrm{~N}$ nitrate. Due to a larger pool size, the highest amounts of ${ }^{15} \mathrm{~N}$ uptake between the belowground compartments were detected in coarse roots. The amounts of tracers retained in coarse roots comprised $4.46-5.29 \mathrm{mg} \mathrm{m}^{-2}$ which conformed $0.050-0.65 \mathrm{mg} \mathrm{g}^{-1}$ after ${ }^{15} \mathrm{~N}$ ammonium and ${ }^{15} \mathrm{~N}$-nitrate additions. The values of ${ }^{15} \mathrm{~N}$ retained in new fine roots grew in sand layer ranged from 2.25 to $3.28 \mathrm{mg} \mathrm{m}^{-2}$ conformed $0.096-0.130 \mathrm{mg} \mathrm{g}^{-1}$, while tracer retained in forest floor fine roots accounted for $0.63-0.70 \mathrm{mg} \mathrm{m}^{-2}$, which conformed $0.034-$ $0.037 \mathrm{mg} \mathrm{g}^{-1}$ after ${ }^{15} \mathrm{~N}$-ammonium and ${ }^{15} \mathrm{~N}$-nitrate additions. In consistent with Magill et al. (1997), the concentration of the ${ }^{15} \mathrm{~N}$ tracer retained in the fine roots system can account for a substantial fraction of $\mathrm{N}$ immobilization in the plants (Table 7). The total amount of ${ }^{15} \mathrm{~N}$ tracer retained in seedlings were lower after ${ }^{15} \mathrm{~N}$-ammonium than after ${ }^{15} \mathrm{~N}$-nitrate $(15.9$ vs. $17.5 \mathrm{mg} \mathrm{m}^{-2}$ ). This suggests that nitrate uptake and deposition could have a greater proportion on seedlings growth than ammonium uptake and deposition. Nitrate may be assimilated by the plants by high energy costs involved in nitrate reduction in fine roots, or 
can utilize extra reductant from the light reactions of photosynthesis to reduce nitrate in foliage (Nadelhoffer et al., 1984). In comparison to other plant compartments the larger amounts of ${ }^{15} \mathrm{~N}$ retained in stems may be attributed to direct uptake or absorption from irrigated solution, as Bowden et al. (1989) hypothesised for nitrogen uptake in Picea rubens trees. In addition, nitrogen uptake by the foliage and retranslocation during the senescence period can also be involved. For the root system, the retained ${ }^{15} \mathrm{~N}$ must be attributed to direct $\mathrm{N}$ uptake and also foliage litter retranslocation of nitrogen products at the end of the season. Recoveries were highest in stems, where the ${ }^{15} \mathrm{~N}$ tracer recovery ranged from $6.92-6.40 \%$ after ${ }^{15} \mathrm{~N}$-ammonium versus ${ }^{15} \mathrm{~N}$-nitrate additions. Percentage recoveries of ${ }^{15} \mathrm{~N}$ tracers in the leaf litter of the second growing period $(0.97-0.75 \%)$ were greater than the leaf litter of the first growing season $(0.23-0.26 \%)$, and when ${ }^{15} \mathrm{~N}$ was added as ammonium versus nitrate.

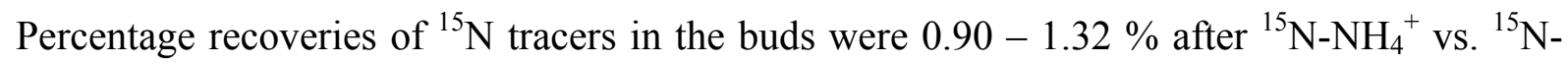
$\mathrm{NO}_{3}{ }^{-}$. The least values for tracer recoveries in beech seedlings were detected in seed leaves, varied between $0.20-0.16 \%$ after ${ }^{15} \mathrm{~N}_{-} \mathrm{NH}_{4}{ }^{+}$vs. ${ }^{15} \mathrm{~N}_{-} \mathrm{NO}_{3}{ }^{-}$. Percent ${ }^{15} \mathrm{~N}$ recoveries in coarse roots averaged $4.80 \%$ after ${ }^{15} \mathrm{~N}$-ammonium and $5.75 \%$ after ${ }^{15} \mathrm{~N}$-nitrate. Percentage recoveries in fine roots system grew in forest floor and in sand layer ranged from $0.68-0.76$ $\%$ and $2.42-3.57 \%$ of tracer inputs after ${ }^{15} \mathrm{~N}_{-} \mathrm{NH}_{4}{ }^{+}$and ${ }^{15} \mathrm{~N}_{-} \mathrm{NO}_{3}{ }^{-}$, respectively. The sum of tracers recovered in measured pools ranged from 17.1 to $19.0 \%$ of ${ }^{15} \mathrm{~N}$ additions, where total percent recoveries were higher after ${ }^{15} \mathrm{~N}_{-} \mathrm{NO}_{3}{ }^{-}$than after ${ }^{15} \mathrm{~N}_{-} \mathrm{NH}_{4}{ }^{+}$inputs. The results of the percentage recoveries in different plant compartments suggests that the fertilized $\mathrm{N}$ taken up by seedlings are assimilated mainly into stems, coarse roots and new fine roots system grew in sand layer. Although fluxes of tracers into seedlings biomass were small, the fact that ${ }^{15} \mathrm{~N}$ recoveries in plant compartments were higher after ${ }^{15} \mathrm{~N}_{-} \mathrm{NO}_{3}{ }^{-}$than after ${ }^{15} \mathrm{~N}_{-} \mathrm{NH}_{4}{ }^{+}$additions, suggests that nitrate deposition could have a greater effect on seedlings growth than ammonium deposition. Reported recoveries of nitrogen applied to plants vary considerably because recovery of nitrogen from fertilizer is dependent on factors such as rate, kind and time of fertilizer application, tree age and size, soil properties, mineralization rates, rain fall and competing vegetation (Nambiar and Bowen, 1986). Buchmann et al. (1996) investigated the partitioning of nitrogen deposition among soil, litter, below- and above-ground biomass of 15 year old Picea abies plantations, found a recovery rates of $14 \%$ after ${ }^{15} \mathrm{~N}$-ammonium and $26 \%$ after ${ }^{15} \mathrm{~N}$-nitrate. Some tracer studies are consistent with our finding that trees compete better for nitrate than for ammonium inputs. For instance, Nadelhoffer et al. (1999) found total percent recoveries of ${ }^{15} \mathrm{~N}$ in the oak and red pine plantations were typically greater after ${ }^{15} \mathrm{~N}_{-} \mathrm{NO}_{3}{ }^{-}$than after ${ }^{15} \mathrm{~N}-\mathrm{NH}_{4}{ }^{+}$additions. Studies of cation surplus in beech tree leaves in 
relation to assimilated nitrogen (Beese 1986) indicated that the beech trees take up mineral nitrogen primarily in the form of nitrate which is then reduced in the leaves. The processes which could have contributed to greater recoveries of tracer after ${ }^{15} \mathrm{~N}_{-} \mathrm{NO}_{3}{ }^{-}$than after ${ }^{15} \mathrm{~N}$ $\mathrm{NH}_{4}{ }^{+}$additions may be the tree species preference for nitrate, or greater competition between tree roots and soil microbes for ammonium (microbial preference for ammonium), or more rapid movement of nitrate to root surfaces (Nadelhoffer et al., 1999). Any or all of these processes could have to some extent contributed to greater recoveries of tracer after ${ }^{15} \mathrm{~N}_{-} \mathrm{NO}_{3}{ }^{-}$ than after ${ }^{15} \mathrm{~N}_{-} \mathrm{NH}_{4}{ }^{+}$inputs. Because ${ }^{15} \mathrm{NH}_{4}{ }^{+}$and ${ }^{15} \mathrm{NO}_{3}^{-}$tracers were applied separately to seedlings receiving ammonium nitrate inputs at experimentally elevated deposition rate, our results can be used to assess how forms and rates of $\mathrm{N}$ inputs affect the partitioning of $\mathrm{N}$ among beech seedlings compartments.

Table 7. The concentration $\left(\mathrm{mg} \mathrm{g}^{-1}\right)$ and amount $\left(\mathrm{mg} \mathrm{m}^{-2}\right)$ of ${ }^{15} \mathrm{~N}$ tracer retained and the percentage tracer recoveries of applied ${ }^{15} \mathrm{~N}$ in above- and below-ground compartments of the beech seedlings and in the whole plant $(n=42)$, (Standard deviation represent in parentheses).

\begin{tabular}{|c|c|c|c|c|c|c|}
\hline \multirow[t]{3}{*}{ pool } & \multicolumn{4}{|c|}{${ }^{15} \mathrm{~N}$ tracer retained } & \multicolumn{2}{|c|}{${ }^{15} \mathrm{~N}$ tracer recovered } \\
\hline & \multicolumn{2}{|c|}{${ }^{15} \mathrm{~N}_{-} \mathrm{NH}_{4}^{+}$} & \multicolumn{2}{|c|}{${ }^{15} \mathrm{~N}-\mathrm{NO}_{3}^{-}$} & ${ }^{15} \mathrm{~N}-\mathrm{NH}_{4}{ }^{+}$ & ${ }^{15} \mathrm{~N}-\mathrm{NO}_{3}{ }^{-}$ \\
\hline & $\left(\mathrm{mg} \mathrm{g}^{-1}\right)$ & $\left(\mathrm{mg} \mathrm{m}^{-2}\right)$ & $\left(\mathrm{mg} \mathrm{g}^{-1}\right)$ & $\left(\mathrm{mg} \mathrm{m}^{-2}\right)$ & \multicolumn{2}{|c|}{$\%$} \\
\hline buds & $0.031(0.01)$ & $0.84(0.32)$ & $0.037(0.01)$ & $1.22(0.49)$ & 0.90 & 1.32 \\
\hline seed leaves & $0.006(0.00)$ & 0.19 & $0.006(0.00)$ & 0.15 & 0.20 & 0.16 \\
\hline leaf litter ( $1^{\text {st }}$ season $)$ & $0.006(0.00)$ & $0.22(0.10)$ & $0.007(0.00)$ & $0.24(0.09)$ & 0.23 & 0.26 \\
\hline leaf litter ( $2^{\text {nd }}$ season $)$ & $0.015(0.00)$ & $0.90(0.48)$ & $0.013(0.00)$ & $0.69(0.31)$ & 0.97 & 0.75 \\
\hline stems & $0.035(0.01)$ & $6.44(3.45)$ & $0.041(0.02)$ & $5.90(3.38)$ & 6.92 & 6.40 \\
\hline coarse roots & $0.050(0.01)$ & $4.46(1.84)$ & $0.065(0.02)$ & $5.29(2.95)$ & 4.80 & 5.75 \\
\hline forest floor fine roots & $0.034(0.02)$ & $0.63(0.34)$ & $0.037(0.03)$ & $0.70(0.61)$ & 0.68 & 0.76 \\
\hline fine roots in sand layer & $0.096(0.03)$ & $2.25(1.30)$ & $0.130(0.03)$ & $3.28(2.64)$ & 2.42 & 3.57 \\
\hline plant (total) & $0.034(0.03)$ & $15.9(4.18)$ & $0.042(0.04)$ & $17.5(5.28)$ & 17.1 & 19.0 \\
\hline
\end{tabular}




\subsection{Conclusion}

It is evident from the results of this experiment that $\mathrm{N}$ fertilization had no apparent effect in alteration of $\mathrm{N}$ immobilization in seedlings as compared to control plants. Fine roots nitrogen concentrations were not affected with $\mathrm{N}$ additions, however the concentration of the ${ }^{15} \mathrm{~N}$ tracer retained demonstrated that the fine roots system can account for a substantial fraction of $\mathrm{N}$ immobilization in the plants. Immobilization of deposited ${ }^{15} \mathrm{~N}$ labeled nitrogen by mycorrhizal fine roots may increase the ${ }^{15} \mathrm{~N}$ sequestration by their turnover which may be detectable in the soil organic matter. In above-ground biomass compartments, stems indicated substantially higher $\mathrm{N}$-immobilization for both $\mathrm{N}$-forms, while the leaf litter due to dilution effect contributed to lower values of immobilized ${ }^{15} \mathrm{~N}$. The total amount of ${ }^{15} \mathrm{~N}$ tracer retained in seedlings were lower after ${ }^{15} \mathrm{~N}$-ammonium than after ${ }^{15} \mathrm{~N}$-nitrate, suggests that nitrate uptake and deposition could have a greater proportion on seedlings growth than ammonium uptake and deposition. Most of the ${ }^{15} \mathrm{~N}$ taken up by the plants was used to build up the above ground seedling (one-third of total plant uptake) and the coarse roots (one-third of total plant uptake). Fine roots account for less than one-fourth. The ${ }^{15} \mathrm{~N}$ transfer to the forest floor via leaf litter in the second year, which were collected in autumn to prevent a ${ }^{15} \mathrm{~N}$ flux via litter fall, was less than $5 \%$ at the end of the experiment. Although this flux is of less importance annually it may be a very important pathway of deposited nitrogen to the forest floor in the long-term. 


\section{Nitrogen transformation in bare and beech covered forest floors}

\subsection{Introduction}

The fate of atmospheric N-deposition in forest ecosystems still is an unresolved problem. It is demonstrated that elevated atmospheric $\mathrm{N}$ inputs to forest ecosystems in long term can lead to increased net $\mathrm{N}$ mineralization and nitrification in soils, increased soil acidification, nutrient imbalances in plant tissues, reductions in plant growth, changes in species composition, altered fluxes of trace gases and increased nitrate leaching and simultaneous base cations losses (Nihlgard, 1985; Aerts and Berendse, 1988; Aber et al., 1989; Bowden et al., 1991). The excessive nitrogen inputs have led to concerns regarding the ability of forest ecosystems to assimilate and retain additional nitrogen with respect to nitrogen inputs may saturate the nitrogen retention capacity of forest ecosystems (Aber et al., 1989; Aber 1992; Durka et al., 1994; Wright and Van Breemen, 1995; Dise and Wright, 1995). The assimilation of N by vegetation is small relative to the quantity of $\mathrm{N}$ retained by soil organic matter (Aber et al., 1993; Magill et al., 1996, 1997; Nadelhoffer et al., 1995). The processes by which $\mathrm{N}$ retention and incorporation occur and the effect on soil nitrogen cycling dynamics are not well understood. Many important transformations of nitrogen within the soil system are microbially driven including immobilization and mineralization of $\mathrm{N}$ during decomposition. Gundersen et al. (1998) argued that although forest soils may have a large capacity to retain N, changes in the vegetation and forest floor were sufficient to change the functioning of the $\mathrm{N}$ cycle and result in $\mathrm{NO}_{3}^{-}$leaching. Thus, the ability to predict $\mathrm{N}$ saturation will require a quantitative understanding of the rates of internal cycling within the plant, forest floor, and within the plantsoil cycle. The application and recovery of ${ }^{15} \mathrm{~N}$ enriched tracers in forests has proven to be a powerful tool for gaining insight into $\mathrm{N}$ fluxes and transformations in soils (Davidson et al. 1990; Tietema and Wessel 1992) and vegetation (Preston et al. 1990).

To understand the fate of ammonium- $\mathrm{N}$ and nitrate- $\mathrm{N}$ deposition in forest stands we conducted a ${ }^{15} \mathrm{~N}$ tracer experiment in Fagus sylvatica seedlings in a green house study. By labelling throughfall with either ${ }^{15} \mathrm{~N}$-ammonium or ${ }^{15} \mathrm{~N}$-nitrate we were able: (i) to follow the partitioning and retention of added ${ }^{15} \mathrm{~N}$ among the plant biomass, forest floor ${ }_{\text {(total) }}$ and the losses through leachate and gaseous forms during two successive growing seasons; (ii) to identify major sinks in different components of the system with respect to $\mathrm{N}$ forms. The purpose of this study is to increase our understanding of nitrogen tansformations in response to throughfall $\mathrm{N}$ deposition in forest ecosystems. 


\subsection{Materials and Methods}

\subsubsection{Study site}

The experimental site is located in the mountain range Solling, Lower Saxony, Germany. The range is situated about $70 \mathrm{~km}$ southwards of Hannover. Solling $\left(51^{\circ} 47^{\prime} \mathrm{N}\right.$ and $\left.9^{\circ} 37^{\prime} \mathrm{E}\right)$ with 740 $\mathrm{km}^{2}$ area is elevated at $200-500 \mathrm{~m}$ a.s.l. and constitutes a watershed between rivers Weser and Leine. Geologically Solling is an uniform massive built of tertiary sandstone covered by a layer of loess at a thickness varying from $20 \mathrm{~cm}$ to $2 \mathrm{~m}$ (average $80 \mathrm{~cm}$ ). In the Solling area Dystric Cambisols and Cambic Podzols dominate (FAO). Pseudogleys and stagnogleys also occure locally. Texture of soils is usually silty loam. The prevailing humus form is typical moder(AK Standortskartierung, 1996). Sixty percent of the surface of Solling is covered by forest. Pure spruce (Picea abies L. Karst.) stands constitute $31 \%$ of the forests, pure beech (Fagus sylvatica L.) stands $17 \%$ and mixed beech-spruce stands $24 \%$ (NMELF, 1996). The climate is characterized by a mean annual temperature of $6.5^{\circ} \mathrm{C}$, mean annual precipitation of $1050 \mathrm{~mm}$ and a frost-free period of 250 days. Three adjacent plots (area of each about $400 \mathrm{~m}^{2}$ ) were chosen for the present study. They included a 100 to 120 year old stands of Norway spruce partly covered by grass, beech and a mixed spruce-beech stand. There was a ground cover grass vegetation at spruce stand due to a surface application of $2.3 \mathrm{t}$ dolomite $\mathrm{ha}^{-1}$ at 1989 .

\subsubsection{Soil sampling and experimental design}

In August 2001, 120 intact soil columns were taken randomly from each stand $(n=40)$ using PVC cylinders (pots) $(15.2 \mathrm{~cm}$ diameter $\times 19 \mathrm{~cm}$ depth). All samples were transferred to a green house partitioned into 4 wagons (diameters $250 \times 92 \times 26 \mathrm{~cm}$ ) with 10 replicates from forest floor samples of each stand at each one. The leachate from each sample passed through a $10 \mathrm{~cm}$ quartz sand in a PVC cylinder set at the bottom of each pot, conducted the leachates through a silicon tube to a brown glass bottle. A cooling system was installed, circulating cool liquid permanently through a flexible tube spiralled four times around each pot to hold the temperature of the samples constant.The sides and the bottom of each wagon were isolated with a $4 \mathrm{~cm}$ thick Styropor. The empty space between the pots at each wagon fill with insulator materials to avoid the waste of temperature. The air and soil temperature were continuously recorded at $5 \mathrm{~cm}$ on top of the forest floor samples and at $3 \mathrm{~cm}$ depth. The samples were artificially irrigated every two days using a bore hole PVC cap ( $5 \mathrm{~cm}$ height) 
contained small nylon threads which came through the fine holes. The applied amounts of cations, anions and heavy metals were calculated on the basis of the long-term annual input at the study area (Matzner, 1989). The element concentrations in the throughfall solution were constant during the experiment. The leachates volume of the soil solutions were collected in 4 weeks intervals and stored at $4^{\circ} \mathrm{C}$ until further processing. The application of throughfall and the sampling of leachates as well as the recording of temperature started from September 2001.

\subsubsection{Treatments}

Some $6-8$ beech seeds were planted in half of the pots $(n=60)$ in depth of $0.5 \mathrm{~cm}$ in the last week of August 2001, which germinated after 3 weeks. The control plants and non-plants treatments, each with 18 replicates, received no nitrogen by throughfall. In the tracer treatments $(n=84)$, plants and non-plants samples were supplied either with $1.17 \mathrm{mg} \mathrm{NO}_{3}-\mathrm{N}$

$\mathrm{L}^{-1}$ as $\mathrm{NH}_{4}{ }^{15} \mathrm{NO}_{3}$ in irrigated water $(n=42)$, or with $1.18 \mathrm{mg} \mathrm{NH} \mathrm{N} \mathrm{L} \mathrm{L}^{-1}$ as ${ }^{15} \mathrm{NH}_{4} \mathrm{NO}_{3}$ by irrigation $(n=42)$ for 442 days. The total amount of nitrogen applied in fertilized plants and non-plants treatments over the course of the experiment accounted for $1.92 \mathrm{~g} \mathrm{~N} \mathrm{~m}^{-2}$ and the total throughfall volume added up to $816 \mathrm{~mm}$.

\subsubsection{Seedlings biomass sampling and analyzes}

Seed leaves and leaf samples of the first vegetation period were taken from the shoot tips about 15 weeks after bud break at December 2001. Leaf samples of the second vegetation year were collected at November 2002. Plant compartments were divided into seed leaves, beech leaves of the first and second year harvesting, stem, coarse roots ( $\geq 3 \mathrm{~mm}$ diameter) and fine roots $(<3 \mathrm{~mm}$ diameter) which involved those in the forest floor containing mycorrhizal and non mycorrhizal root tips and fine roots developed in sand layer beneath them. The root system partitioned by size and depth in order to represent some trends in biomass, nutrient concentrations and ${ }^{15} \mathrm{~N}$ distribution between the below-ground biomass compartments. Roots were separated from the forest floor by washing and sieving method for several times. The mycorrhizal and non mycorrhizal root tips from each sample were essentially collected from the fine roots developed in forest floors and divided into three replicate samples before ${ }^{15} \mathrm{~N}$ analyzes. All tree biomass compartments as well as the collected foliage litter $\left(\mathrm{O}_{\mathrm{L}}\right)$ were dried at $65^{\circ} \mathrm{C}$ for $96 \mathrm{~h}$, milled, homogenized and weighed before $\mathrm{N}$ content and ${ }^{15} \mathrm{~N}$ analyzes. Stems and coarse roots were milled in a planetary mill (Retsch, Hann, Germany), the other plant 
components ground in a piston-action ball mill. Carbon and Nitrogen concentrations were calculated on a mass basis and are expressed as a percentage of dry mass.

\subsection{5 ${ }^{15} \mathrm{~N}$ mass measurements}

The ${ }^{14} \mathrm{~N} /{ }^{15} \mathrm{~N}$ isotope measurements were made with an isotope ratio mass spectrometer (Delta Plus, Finnigan Mat GmbH, Bremen, Germany) coupled to an elemental analyzer (EA 1108, Fisons, Rodano, Milan, Italy) in online mode. ${ }^{15} \mathrm{~N}$ abundance is expressed in atom percent by the ratio:

$$
\text { Atom } \%{ }^{15} \mathrm{~N}=\frac{{ }^{15} N}{{ }^{14} N+{ }^{15} N} \times 100
$$

Values of ${ }^{15} \mathrm{~N}$ enrichment (atom $\%{ }^{15} \mathrm{~N}$ excess) were calculated by subtracting ${ }^{15} \mathrm{~N}$ values from ${ }^{15} \mathrm{~N}$ natural abundance of the control. For determination of ${ }^{15} \mathrm{~N}$ concentrations of soil and plant materials total $\mathrm{N}$ content and the biomass of the respective parts were taken into consideration.

Total ${ }^{15} \mathrm{~N}$ content $=\left({ }^{15} N_{t}-{ }^{15} N_{c}\right) \times[N] \times$ plant biomass or forest floor mass

Where ${ }^{15} \mathrm{~N}_{\mathrm{t}}$ and ${ }^{15} \mathrm{~N}_{\mathrm{c}}$ are the atom \% concentrations of ${ }^{15} \mathrm{~N}$ in treated and control plants, respectively, $[\mathrm{N}]$ is the total $\mathrm{N}$ concentration (of a $\mathrm{g}$ dry weight) of plant compartment. For estimation of ${ }^{15} \mathrm{~N}$ uptake per plant, the ${ }^{15} \mathrm{~N}$ concentration of above and below ground parts were summed up.

Tracers recovered in pools were expressed as proportions of total ${ }^{15} \mathrm{~N}$ tracer applied over the course of experiment.

$$
\%{ }^{15} \mathrm{~N} \text { recovery }=\frac{\left.\left[\mathrm{N}_{\text {pool }} \times\left(\text { atom } \%{ }^{15} \mathrm{~N}_{\text {pool }}-\text { atom } \%{ }^{15} \mathrm{~N}_{\text {control }}\right)\right] \times \mathrm{m}_{\text {pool }}\right]}{\left[\mathrm{N}_{\text {applied }} \times\left(\text { atom } \%{ }^{15} \mathrm{~N}_{\text {tracer }}-\text { atom } \%{ }^{15} \mathrm{~N}_{\text {ref. }}\right)\right] \times \text { irrigation volume }} \times 100
$$

Where, ${ }^{15} \mathrm{~N}$ recovery, the percent ${ }^{15} \mathrm{~N}$ tracer recovered in the labelled $\mathrm{N}$ pool $(\%) . \mathrm{N}_{\text {pool }}$, the concentration of total $\mathrm{N}$ in the labelled $\mathrm{N}$ pool $\left(\mathrm{mg} \mathrm{g}^{-1}\right)$. atom $\%{ }^{15} \mathrm{~N}$ pool, atom percent ${ }^{15} \mathrm{~N}$ in the labelled $\mathrm{N}$ pool. atom $\%{ }^{15} \mathrm{~N}$ control, atom percent ${ }^{15} \mathrm{~N}$ in the control (non-labelled) $\mathrm{N}$ pool, $\mathrm{m}_{\text {pool }}, \mathrm{N}$ mass of the labelled $\mathrm{N}$ pool $(\mathrm{g}), \mathrm{N}$ applied, the concentration of the fraction $\left(\mathrm{NO}_{3}-\mathrm{N}\right.$ or 
$\left.\mathrm{NH}_{4}-\mathrm{N}\right)$ in irrigated water $\left(\mathrm{mg} \mathrm{L}^{-1}\right)$. atom $\%{ }^{15} \mathrm{~N}$ tracer, atom percent of the applied tracer. atom ${ }^{0}{ }^{15} \mathrm{~N}$ ref., atom percent ${ }^{15} \mathrm{~N}$ in the reference (non-labelled) $\mathrm{N}$ pool, irrigation volume, total precipitation (L).

\subsection{6 $\mathrm{CO}_{2}$ and $\mathrm{N}_{2} \mathrm{O}$ emissions}

$\mathrm{CO}_{2}$ and $\mathrm{N}_{2} \mathrm{O}$ fluxes from each sample were measured once per month from early October 2001 through late November 2002. After closing the headspace by a gas-tight lid above the column, gas samples were taken with evacuated glass bottles $(100 \mathrm{ml})$ after 0 and $20 \mathrm{~min}$ of incubation via a small silicon tube connecting the lid and the glass bottle. Gas samples were analysed by injection of gas sample into the port of a gas chromatograph (GC $14 \mathrm{~A}$, Shimadzu, Duisburg, Germany) equipped with two detectors, a flame ionization detector (FID), and an electron capture detector (ECD). (Loftfield et al. 1997). The $\mathrm{CO}_{2}$ or $\mathrm{N}_{2} \mathrm{O}$ emissions were calculated using linear regression of the change in gas concentrations, based on the following equation:

$F=k \mathrm{CO} 2$ or $k \mathrm{~N} 2 \mathrm{O} \frac{273}{T} \frac{P}{101} \frac{V}{A} \frac{\Delta C}{\Delta t}$

$F$ is the flux rate of $\mathrm{CO}_{2}\left(\mathrm{mg} \mathrm{CO}_{2}-\mathrm{C} \mathrm{m}^{-2} \mathrm{~h}^{-1}\right)$ or $\mathrm{N}_{2} \mathrm{O}\left(\mu \mathrm{g} \mathrm{N} \mathrm{N}_{2} \mathrm{O}-\mathrm{N} \mathrm{m}^{-2} \mathrm{~h}^{-1}\right), k_{\mathrm{CO} 2}\left(0.536 \mu \mathrm{g} \mathrm{C} \mu \mathrm{l}^{-}\right.$ $\left.{ }^{1}\right), k_{\mathrm{N} 2 \mathrm{O}}\left(1.25 \mu \mathrm{g} \mathrm{N} \mu \mathrm{l}^{-1}\right)$ are unit conversion factors for calculating $\mathrm{CO}_{2}$ and $\mathrm{N}_{2} \mathrm{O}$ flux rates, $T$ is the air temperature $\left({ }^{\circ} \mathrm{K}\right), \mathrm{P}$ is the atmospheric pressure $(\mathrm{k} \mathrm{Pa}), V$ is the air volume of the headspace gas above the samples (1), $A$ is the area of humus samples $\left(\mathrm{m}^{2}\right)$ and $\Delta C / \Delta t$ is the rate of change in concentration of $\mathrm{CO}_{2}$ and $\mathrm{N}_{2} \mathrm{O}$, within the headspace $\left(\mu \mathrm{l}^{-1} \mathrm{~h}^{-1}\right)$. 


\subsubsection{Forest floor biochemical analyzes}

All forest floor samples of the control and ${ }^{15} \mathrm{~N}$-fertilized treatments were hemogenized well to analyse nitrate and ammonium concentrations with $0.5 \mathrm{M} \mathrm{K}_{2} \mathrm{SO}_{4}$ solution. Moisture content was determined on sub-samples by drying to constant weight at $105^{\circ} \mathrm{C}$. Microbial $\mathrm{C}\left(\mathrm{C}_{\text {mic }}\right)$ and $\mathrm{N}\left(\mathrm{N}_{\text {mic }}\right)$ were determined using the chloroform fumigation-extraction method (Brookes et al., 1985). $50 \mathrm{~g}$ field-moist sub-samples in two replicates were taken, One pair was immediately extracted with $0.5 \mathrm{M} \mathrm{K}_{2} \mathrm{SO}_{4}$ (approx. 5:1 ratio of solution to dry weight soil). The other pair was fumigated for 5 days with ethanol-free chloroform. Subsequently the chloroform was removed by evacuation and the soils were extracted by $0.5 \mathrm{M} \mathrm{K}_{2} \mathrm{SO}_{4}(\sim 5: 1$ ratio of solution to dry mass soil). The differences in organic $\mathrm{C}$ and total $\mathrm{N}$ extracted between the fumigated and non fumigated samples ( $\mathrm{C}$ and $\mathrm{N}$ flushes) are assumed to represent the $\mathrm{C}$ and $\mathrm{N}$ released from lysed soil microbes. The $\mathrm{C}$ and $\mathrm{N}$ flushes were converted to microbial biomass $\mathrm{C}$ and $\mathrm{N}$, respectively, using a correction factor $k_{\mathrm{C}}=0.45$ (Joergensen, 1996) and $k_{\mathrm{N}}$ $=0.68$ for $5 \mathrm{~d}$ fumigated soils (Brookes et al., 1985). The Organic $\mathrm{C}$ in the $\mathrm{K}_{2} \mathrm{SO}_{4}$ extracts was analyzed by dry combustion at $680^{\circ} \mathrm{C}$ using TOC 5050 A shimadzu carbon analyzer (Shimadzu GmbH, Duisburg, Germany). The extracted ammonium, nitrate and total N were analysed by a continuous flow system spectrophotometer (Skalar Analytic GmbH, 41812 Erkelenz, Germany) (Koenig and Fortmann, 1996). A sub-sample of forest floor in each pot was analysed to determine total $\mathrm{C}$ and $\mathrm{N}$ by dry combustion in a $\mathrm{CN}$-auto analyser (Vario, Elementar Analysensysteme, Hanau, Germany) and soil pH (digital pH-meter, WTW GmbH Wesl-Germany). One sub-sample in two replicates from control and ${ }^{15} \mathrm{~N}$-labeled forest floors were taken to analyze the values of ${ }^{15} \mathrm{~N}$ in each soil sample by an isotope ratio mass spectrometer (Delta Plus, Finnigan Mat GmbH, Bremen, Germany).

\subsubsection{Leachate chemical analyzes}

Leachates were analyzed for $\mathrm{NO}_{3}{ }^{-}-\mathrm{N}$ and $\mathrm{NH}_{4}{ }^{+}-\mathrm{N}$ and total $\mathrm{N}$ using a continuous flow system spectrophotometer (Skalar Analytic GmbH, 41812 Erkelenz, Germany) (Koenig and Fortmann, 1996). DON was calculated as TDN $-\mathrm{DIN}$ where $\mathrm{DIN}=\mathrm{NO}_{3}{ }^{-} \mathrm{N}+\mathrm{NH}_{4}{ }^{+}-\mathrm{N}$. The concentrations of dissolved organic carbon (DOC) in leachates were measured using a Total Organic carbon Analyser TOC - 5050 (Shimadzu Corp., Tokyo, Japan). For estimation of ${ }^{15} \mathrm{~N}$ in leachates, total dissolved nitrogen (TDN) in ${ }^{15} \mathrm{~N}$ fertilized and control samples were determined using an adaptation of the persulfate-base digestion procedure technique in which 
all $\mathrm{NO}_{3}{ }^{-}$present is volatilized as $\mathrm{HNO}_{3}$ in closed tubes prior to ${ }^{15} \mathrm{~N}$ diffusion (Wyland et al., 1994; Stark and Hart, 1996). The ${ }^{15} \mathrm{~N}$ enrichment was measured by the continuous flow system spectrophotometer after oxidation of $10 \mathrm{ml}$ of perculate in $10 \mathrm{ml}$ oxidizing reagent followed by steam distillation of the perculate with $10 \mathrm{M} \mathrm{NaOH}$ to buffer the solution and volatilize $\mathrm{NH}_{3}$ and evaporation of the $\left(\mathrm{NH}_{4}\right)_{2} \mathrm{SO}_{4}$ distillates adjusted to $\mathrm{pH} 4$. This method is preferred over the Total Kjeldahl Nitrogen method for samples containing high amounts of $\mathrm{NO}_{3}{ }^{-}$, since $\mathrm{NH}_{4}{ }^{+}$and organic nitrogen are converted to $\mathrm{NO}_{3}{ }^{-}$.

\subsubsection{Statistical analyses}

The Mann-Whitney U-Test at $p<0.05$ level, was used to evaluate the significance of differences between the treatments in individual plant compartments, performed by the program Statistica version 6.0. 


\subsection{Results and discussion}

\subsubsection{N budgets}

Estimated $\mathrm{N}$ budgets for all treatments were calculated as a total input minus output (leaching and $\mathrm{N}_{2} \mathrm{O}$ fluxes) and net plant $\mathrm{N}$ uptake over a period of 442 days experiment time (Table 1). Total input of nitrogen applied as ${ }^{15} \mathrm{~N}$-labelled $\mathrm{NH}_{4} \mathrm{NO}_{3}$ was equivalent $1.92 \mathrm{~g} \mathrm{~N} \mathrm{~m}^{-2}$. Nitrogen leaching losses as the main fraction of $\mathrm{N}$ output were calculated as total dissolved nitrogen below the rooting zone varied between $6.41 \mathrm{~g} \mathrm{~N} \mathrm{~m}^{-2}$ and $10.0-7.58 \mathrm{~g} \mathrm{~N} \mathrm{~m}^{-2}$ in the control and ${ }^{15} \mathrm{~N}$-fertilized plants treatments. In corresponding non-plants treatments the values of the leached $\mathrm{N}$ ranged from $8.02 \mathrm{~g} \mathrm{~N} \mathrm{~m}^{-2}$ to $11.6-9.58 \mathrm{~g} \mathrm{~N} \mathrm{~m}^{-2}$, respectively. The amounts of nitrogen leaching losses increased markedly with $\mathrm{N}$ additions across the control and ${ }^{15} \mathrm{~N}$ fertilized treatments. The balance values of $\mathrm{N}_{2} \mathrm{O}$ efflux between the plants treatments ranged from $0.42 \mathrm{~g} \mathrm{~N} \mathrm{~m}^{-2}$ in the control to $0.54-0.40 \mathrm{~g} \mathrm{~N} \mathrm{~m}^{-2}$ in ${ }^{15} \mathrm{~N}$-fertilized and varied between $0.46 \mathrm{~g} \mathrm{~N} \mathrm{~m}^{-2}$ and $0.52-0.41 \mathrm{~g} \mathrm{~N} \mathrm{~m}^{-2}$ in corresponding non-plants treatments. Analyses of variance $(p<0.05)$ revealed no significant effect of ${ }^{15} \mathrm{~N}$-fertilizer on balanced values of $\mathrm{N}_{2} \mathrm{O}$ losses between the plants and non plants treatments. The $\mathrm{N}_{2} \mathrm{O}$ flux rates are in magnitude in consistent with the flux rates observed in Solling forest, Germany, subjected to high levels of atmospheric $\mathrm{N}$ deposition, (Brumme and Beese, 1992; Brumme et al., 1999) they do indicated that atmospheric $\mathrm{N}$ deposition can stimulate $\mathrm{N}$-cycling processes (particularly nitrification) that are important in controlling rates of $\mathrm{N}_{2} \mathrm{O}$ emissions. The net nitrogen uptake by beech seedlings from forest floor supply $\left(1.36 \mathrm{~g} \mathrm{~N} \mathrm{~m}^{-2}\right.$ in control to $1.01-1.66 \mathrm{~g} \mathrm{~N} \mathrm{~m}^{-2}$ in ${ }^{15} \mathrm{~N}$ fertilized) statistically were not affected with $\mathrm{N}$ additions. The calculated balance values of nitrogen ( $\mathrm{N}$ budgets) over a period of 442 days experiment time ranged from $-8.19 \mathrm{~g} \mathrm{~N} \mathrm{~m}^{-2}$ in the control to $-9.62--8.14 \mathrm{~g} \mathrm{~N} \mathrm{~m}^{-2}$ in ${ }^{15} \mathrm{~N}$-fertilized plants treatments and varied between $8.48 \mathrm{~g} \mathrm{~N} \mathrm{~m}^{-2}$ and $-10.1--8.07 \mathrm{~g} \mathrm{~N} \mathrm{~m}^{-2}$ in corresponding non-plants treatments. Comparing the balance values of nitrogen across the treatments showed a tendency to increase on net nitrogen mineralization after ${ }^{15} \mathrm{~N}$-nitrate application, although no significant effect of $\mathrm{N}$ additions were detected between the control and ${ }^{15} \mathrm{~N}$-fertilized treatments. Aber et al. (1989) hypothesized a slow, continuous increase in net $\mathrm{N}$ mineralization as added nitrogen was incorporated into the cycle through plant uptake, litter fall, and decomposition. In consistent, Gunderson et al. (1998) reported increases in field measured net $\mathrm{N}$ mineralization rates with $\mathrm{N}$ additions only at $\mathrm{N}$ limited sites, while those with high initial rates of $\mathrm{N}$ cycling showeddecreases in net $\mathrm{N}$ mineralization with further $\mathrm{N}$ additions. In the NITREX studies in 
Europe, Tietema (1998), using ${ }^{15} \mathrm{~N}$ pool dilution, found increases in both gross mineralization and gross immobilization rates across a nitrogen deposition gradient, but net $\mathrm{N}$ mineralization peaked at intermediate $\mathrm{N}$ deposition. Aber et al. (1998) reported initial increases in $\mathrm{N}$ mineralization with chronic $\mathrm{N}$ additions at the Harvard Forest study site were followed by actual decreases in net $\mathrm{N}$ mineralization by the sixth year of application. The $\Delta \mathrm{N}$ balance difference between the plants and non-plants treatments were after ${ }^{15} \mathrm{~N}_{-} \mathrm{NO}_{3}{ }^{-}\left(0.48 \mathrm{~g} \mathrm{~N} \mathrm{~m}^{-2}\right)$ slightly higher and after ${ }^{15} \mathrm{~N}_{-} \mathrm{NH}_{4}{ }^{+}\left(-0.07 \mathrm{~g} \mathrm{~N} \mathrm{~m}^{-2}\right)$ lower than the $\Delta \mathrm{N}$ balance difference of the control plants and non-plants treatments $\left(0.28 \mathrm{~g} \mathrm{~N} \mathrm{~m}^{-2}\right)$. These data implies nearly equal total $\mathrm{N}$ balance across the treatments, as the biomass and $\mathrm{N}$ concentration of the fine roots in ${ }^{15} \mathrm{~N}$ fertilized were not affected with $\mathrm{N}$ additions in compare to control plants treatment.

Table 1. The input and leachate of nitrogen, total plant $\mathrm{N}$ uptake, the balance values of $\mathrm{N}_{2} \mathrm{O}$ emissions and the total balance of nitrogen within the control $(n=18)$ and the two labelled-N forms $(n=21)$ of the ${ }^{15} \mathrm{~N}$-fertilized plants and non-plants treatments over a period of 442 days, (Standard deviation represent in parentheses).

\begin{tabular}{lcccccc}
\hline treatment & N-input & N-leachate & $\mathrm{N}_{2} \mathrm{O}$ efflux & plant N uptake & N balance & $\Delta$ N balance \\
\cline { 3 - 7 } control (plants) & 0 & $6.41(0.58)$ & $0.42(0.33)$ & $1.36(1.96)$ & $-8.19(2.07)$ & 0.28 \\
\cline { 2 - 6 } control & 0 & $8.02(0.83)$ & $0.46(0.64)$ & - & $-8.48(1.05)$ & \\
$\mathrm{NH}_{4}{ }^{15} \mathrm{NO}_{3}$ (plants) & $1.92(0.009)$ & $10.0(1.24)$ & $0.54(0.42)$ & $1.01(1.90)$ & $-9.62(2.31)$ & \\
$\mathrm{NH}_{4}{ }^{15} \mathrm{NO}_{3}$ & $1.92(0.009)$ & $11.6(1.08)$ & $0.52(0.54)$ & - & $-10.1(1.20)$ & 0.48 \\
${ }^{15} \mathrm{NH}_{4} \mathrm{NO}_{3}$ (plants) & $1.92(0.016)$ & $7.58(0.82)$ & $0.40(0.28)$ & $1.66(1.93)$ & $-8.14(2.11)$ & \\
${ }^{15} \mathrm{NH}_{4} \mathrm{NO}_{3}$ & $1.92(0.016)$ & $9.58(0.93)$ & $0.41(0.24)$ & - & $-8.07(0.96)$ & -0.07 \\
\hline
\end{tabular}




\subsubsection{Impact of ${ }^{15} \mathrm{~N}$-fertilizer on nitrogen immobilization in forest floor}

The effect of ${ }^{15} \mathrm{~N}$ additions on microbial immobilization through measurements of microbial biomass $\left(\mathrm{C}_{\text {mic }}\right)$ in $\mathrm{O}_{\mathrm{F}}+\mathrm{O}_{\mathrm{H}}$ differed between the treatments. While the values of microbial biomass $\mathrm{C}$ in ${ }^{15} \mathrm{~N}$-fertilized plants treatments were markedly higher than the values of corresponding control treatment, no significant effect of $\mathrm{N}$ additions were detected between the non plants treatments (Table 2). The same trend of differences were detected also by comparing the microbial $\mathrm{C}: \mathrm{N}$ ratios between the ${ }^{15} \mathrm{~N}$-fertilized plants and non-plants with corresponding control treatments. Analyses of variance $(p<0.05)$ revealed no significant differences on $\mathrm{N}$ immobilization in microbial biomass $\left(\mathrm{N}_{\text {mic }}\right)$ across the control and the corresponding ${ }^{15} \mathrm{~N}$-fertilized treatments (Table 2). This can be explained by rapid microbial immobilization/remineralization of added mineral $\mathrm{N}$ as the major process by which added nitrate and ammonium immobilized in the forest floor. The balance values of $\mathrm{CO}_{2}$ efflux across plants treatments ranged from $418 \mathrm{~g} \mathrm{C} \mathrm{m}^{-2}$ in the control to $422-428 \mathrm{~g} \mathrm{C} \mathrm{m}^{-2}$ in ${ }^{15} \mathrm{~N}$ fertilized and $205 \mathrm{~g} \mathrm{C} \mathrm{m}^{-2}$ to $233-278 \mathrm{~g} \mathrm{C} \mathrm{m}^{-2}$ in corresponding non-plants treatments (Table 3). Analyzes of variance $(p<0.05)$ indicated significant differences on the balance of $\mathrm{CO}_{2}$ efflux between the plants treatments and the corresponding non-plants, while differences across control and ${ }^{15} \mathrm{~N}$-fertilized treatments were undetectable. The markedly higher soil $\mathrm{CO}_{2}$ efflux by plants treatments could be attributed to fine roots respiration rather than immobilization of added nitrogen through microbial biomass production, as $\mathrm{CO}_{2}$ flux rates were not affected by addition of ${ }^{15} \mathrm{~N}_{-} \mathrm{NH}_{4}{ }^{+}$or ${ }^{15} \mathrm{~N}-\mathrm{NO}_{3}{ }^{-}$. In the present study, after 442 days of tracer application the amounts of ${ }^{15} \mathrm{~N}$ retained in the forest floors accounted for $32.2-31.4$ $\mathrm{mg} \mathrm{m}{ }^{-2}$ after ${ }^{15} \mathrm{~N}$-ammonium versus $12.0-8.29 \mathrm{mg} \mathrm{m}^{-2}$ after ${ }^{15} \mathrm{~N}$-nitrate in plants and non plants treatments (Table 4). The total recoveries of the applied ${ }^{15} \mathrm{~N}$ retained in the forest floors

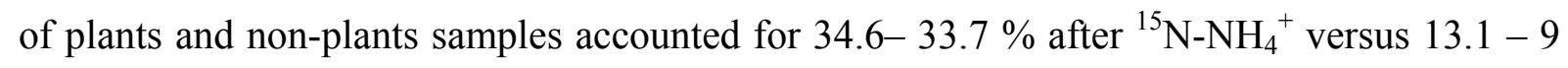
$00 \%$ after ${ }^{15} \mathrm{~N}_{-} \mathrm{NO}_{3}{ }^{-}$in fertilized plants and non-plants treatments. This states that biotic and abiotic ammonium assimilation capacities of the forest floors were more exceeded with $\mathrm{N}$ additions, than were the nitrate assimilation capacities, as tracer recoveries from forest floors were three times greater when ${ }^{15} \mathrm{~N}_{-} \mathrm{NH}_{4}{ }^{+}$rather than ${ }^{15} \mathrm{~N}_{-} \mathrm{NO}_{3}{ }^{-}$were applied (Durka et al. 1994; Buchmann et al. 1996). Short term studies of ${ }^{15} \mathrm{~N}$ immobilization into forest soils reveal that a significant portion of labelled $\mathrm{N}$ is incorporated into non-extractable or recalcitrant pools (e.g., Vitousek and Matson 1985). In consistent with present results, Groffman et (1993) traced ammonium and nitrate in a temperate forest in Michigan, USA, found higher immobilization rates for ammonium (60\%) than for nitrate (48 \%) in a short term experiment 
in forest soils. Nadelhoffer et al. (1992) reported similar results for a ${ }^{15} \mathrm{~N}$-ammonium tracer study in a hardwood mixed forest where $67 \%$ of the ${ }^{15} \mathrm{~N}$ input was found in the surface soil (0 $-5 \mathrm{~cm}$ ) after one growing season. Strickland et al. (1992) demonstrated rapid incorporation of ${ }^{15} \mathrm{~N}$ into a non-microbial, physically shielded soil pool (slow turnover pool) but stated that the mechanisms by which the process accomplished need further study. Most of the ${ }^{15} \mathrm{~N}$ pool dilution studies show a near immediate disappearance of labelled $\mathrm{N}$, which has been attributed to abiotic processes (e.g. Schimel and Firestone 1989). These results are consistent with the model of Aber et al. (1991) who modelled the fate of N under "nitrogen saturation" conditions and predicted that a large percentage of nitrogen would be held in the soil organic matter.

Table 2 . Mean characteristics of the $\mathrm{O}_{\mathrm{F}}+\mathrm{O}_{\mathrm{H}}$ horizons including the thin $\mathrm{A}_{\mathrm{h}}$ layer $(\sim 1.5 \mathrm{~cm})$ beneath the organic matter in the control $(n=18)$ and ${ }^{15} \mathrm{~N}$-fertlized plants and non-plants treatments $(n=21)$, measured at the end of the experiment, (Standard deviation represent in parentheses).

\begin{tabular}{|c|c|c|c|c|c|c|c|c|c|c|c|}
\hline \multirow[t]{2}{*}{ treatment } & \multirow{2}{*}{$\frac{\text { depth }}{(\mathrm{cm})}$} & \multirow{2}{*}{$\frac{\text { mass }}{\left(\mathrm{Mg} \mathrm{ha}^{-1}\right)}$} & \multicolumn{2}{|c|}{$\mathrm{pH}$} & $\mathrm{C}_{\text {org }}$ & $\mathrm{N}_{\text {tot }}$ & \multirow[t]{2}{*}{$\mathrm{C} / \mathrm{N}$} & $\mathrm{C}_{\mathrm{mic}}$ & $\mathrm{N}_{\text {mic }}$ & \multirow[t]{2}{*}{$\mathrm{C}_{\mathrm{mic}} / \mathrm{N}_{\text {mic }}$} & \multirow[t]{2}{*}{$\mathrm{C}_{\text {mid }} / \mathrm{C}_{\text {org }}$} \\
\hline & & & $\overline{\left(\mathrm{H}_{2} \mathrm{O}\right)}$ & $(\mathrm{KCl})$ & \multicolumn{2}{|c|}{$\left(\mathrm{g} \mathrm{kg}^{-1}\right)$} & & \multicolumn{2}{|c|}{$\left(\mathrm{mg} \mathrm{kg}^{-1}\right)$} & & \\
\hline \multirow[t]{2}{*}{ control (plants) } & 6.67 & 242 & 3.69 & 2.98 & 172 & 8.83 & 19.2 & 1768 & 158.0 & 11.5 & 1.05 \\
\hline & $(0.83)$ & $(76.0)$ & $(0.34)$ & $(0.43)$ & $(60.8)$ & $(2.71)$ & $(1.63)$ & (583) & $(57.0)$ & $(1.86)$ & $(0.17)$ \\
\hline \multirow[t]{2}{*}{ control } & 6.72 & 227 & 3.74 & 2.92 & 170 & 9.94 & 18.2 & 1924 & 159.5 & 12.4 & 1.19 \\
\hline & $(1.00)$ & $(66.4)$ & $(0.34)$ & $(0.39)$ & $(78.6)$ & $(4.58)$ & $(3.22)$ & $(826)$ & $(77.8)$ & $(2.07)$ & $(0.27)$ \\
\hline \multirow[t]{2}{*}{$\mathrm{NH}_{4}{ }^{15} \mathrm{NO}_{3}$ (plants) } & 6.33 & 205 & 3.68 & 2.98 & 175 & 8.94 & 19.4 & 2266 & 187.4 & 12.1 & 1.32 \\
\hline & $(0.90)$ & $(67.4)$ & $(0.33)$ & $(0.31)$ & $(62.3)$ & $(2.80)$ & $(1.27)$ & (722) & $(58.3)$ & $(1.16)$ & $(0.24)$ \\
\hline \multirow[t]{2}{*}{$\mathrm{NH}_{4}{ }^{15} \mathrm{NO}_{3}$} & 6.17 & 222 & 3.71 & $(2.92)$ & 144 & 7.92 & 18.0 & 1732 & 150.2 & 11.6 & 1.22 \\
\hline & $(1.20)$ & $(52.5)$ & $(0.32)$ & $(0.33)$ & $(36.8)$ & $(1.62)$ & $(1.47)$ & (473) & $(43.2)$ & $(1.18)$ & $(0.28)$ \\
\hline \multirow[t]{2}{*}{${ }^{15} \mathrm{NH}_{4} \mathrm{NO}_{3}$ (plants) } & 6.38 & 256 & 3.74 & 3.06 & 142 & 7.13 & 20.9 & 1973 & 161.7 & 12.4 & 1.30 \\
\hline & $(1.42)$ & $(74.6)$ & $(0.43)$ & $(0.46)$ & $(49.7)$ & $(2.03)$ & $(2.16)$ & (710) & $(65.3)$ & $(1.11)$ & $(0.39)$ \\
\hline \multirow[t]{2}{*}{${ }^{15} \mathrm{NH}_{4} \mathrm{NO}_{3}$} & 6.45 & 239 & 3.71 & 2.92 & 147 & 7.93 & 18.3 & 2002 & 159.3 & 12.7 & 1.43 \\
\hline & $(1.53)$ & $(73.6)$ & $(0.46)$ & $(0.47)$ & $(51.4)$ & $(2.20)$ & $(2.18)$ & $(665)$ & $(55.5)$ & $(1.40)$ & $(0.53)$ \\
\hline
\end{tabular}




\subsubsection{Impact of ${ }^{15} \mathrm{~N}$-fertilizer on dissolved organic carbon and nitrogen}

The flux concentrations of DOC increased significantly $(P<0.05)$ from control to ${ }^{15} \mathrm{~N}$ fertilized plants treatments, ranged from $27.8 \mathrm{mg} \mathrm{C} \mathrm{L}^{-1}$ to $33.4-36.6 \mathrm{mg} \mathrm{C} \mathrm{L}^{-1}$, while in corresponding non-plants treatments the solute concentrations of carbon, varied between 28.4 mg C L ${ }^{-1}$ and $26.0-28.5 \mathrm{mg} \mathrm{C} \mathrm{L}^{-1}$, were not affected with $\mathrm{N}$ inputs (Table 3). The markedly higher solute concentrations of the organic carbon in ${ }^{15} \mathrm{~N}$-fertilized plants treatments suggesting the effect of fine roots exudates on decomposition rates of polar extractable compounds in the forest floor via promoting the metabolism of DOC by heterotrophs in the presence of the most easily assimilated form of added mineral nitrogen. The well correlated relation between the fine roots biomass and the flux rates of $\mathrm{CO}_{2}$ from plants treatments can certify the importance of fine roots on promoting metabolism of dissolved organic carbon released from the forest floor. The flux concentrations of DON released from the forest floors increased markedly from $0.96 \mathrm{mg} \mathrm{N} \mathrm{m}^{-2}$ in the control to $1.19-1.18 \mathrm{mg} \mathrm{N} \mathrm{m}^{-2}$ in ${ }^{15} \mathrm{~N}$ fertilized plants treatments, while the DON losses in non-plants treatments exhibited only a tendency to increase in the range of $0.95 \mathrm{mg} \mathrm{N} \mathrm{m}^{-2}$ in the control to $0.97-1.06 \mathrm{mg} \mathrm{N}$ $\mathrm{m}^{-2}$ in ${ }^{15} \mathrm{~N}$-fertilized treatments. According to Aber et al. (1998) the increased incorporation of added $\mathrm{N}$ into dissolved organic nitrogen is one of the mechanisms controlling the nitrogen retention in the forest floors. The present results suggest that the conversion of added mineral $\mathrm{N}$ to DON could be one of processes for conveying added $\mathrm{N}$ into forest floor, even though DON is never a large pool. In ${ }^{15} \mathrm{~N}$-fertilized non-plants treatments nitrogen availability did not appear to alter the fluxes of DOC from the forest floors, however, increased $\mathrm{N}$ availability showed a tendency to increase the DON fluxes resulted in the narrowing the leachate DOCto-DON ratio (Magill et al., 2000). DOC-to-DON ratios, expressed the role of dissolved organic matter as an instrument for transport of nitrogen, ranged from 29.5 to $27.8-30.8$ in the control and ${ }^{15} \mathrm{~N}$-fertilized plants treatments and varied between 30.2 and $26.6-27.2$ in corresponding non-plants treatments (Table 3). The tendency of DOC-to-DON across the treatments demonstrated non-significantly narrower ratios in treatments with $\mathrm{N}$ additions in compare to corresponding control plants and non-plants treatments, except slightly higher ratio after ${ }^{15} \mathrm{~N}_{-} \mathrm{NH}_{4}{ }^{+}$plants treatment. Currie et al (1996) reported that chemical incorporation of mineral $\mathrm{N}$ into dissolved organic matter followed by resorption of the now $\mathrm{N}$ enriched dissolved organic nitrogen resulted in decreased DOC-to-DON ratios. 
Table 3. The balance values of $\mathrm{CO}_{2}$ emissions and mean solute concentrations of dissolved carbon and nitrogen in leachate of the control $(n=18)$ and the two labelled-N forms $(n=21)$ of the ${ }^{15} \mathrm{~N}$-fertilized plants and non-plants treatments over the course of experiment, (Standard deviation represent in parentheses).

\begin{tabular}{|c|c|c|c|c|}
\hline \multirow[t]{2}{*}{ treatment } & \multirow{2}{*}{$\frac{\mathrm{CO}_{2} \text { efflux }}{\left(\mathrm{g} \mathrm{C} \mathrm{m}^{-2}\right)}$} & \multirow{2}{*}{$\frac{\text { DOC }}{\left(\mathrm{mg} \mathrm{C} \mathrm{L}^{-1}\right)}$} & \multirow{2}{*}{$\frac{\text { DON }}{\left(\mathrm{mg} \mathrm{N} \mathrm{L}^{-1}\right)}$} & \multirow[t]{2}{*}{$\mathrm{DOC} / \mathrm{DON}$} \\
\hline & & & & \\
\hline control (plants) & $418(107)$ & $27.8(6.37)$ & $0.96(0.20)$ & $29.5(6.04)$ \\
\hline control & $205(63.0)$ & $28.4(6.67)$ & $0.95(0.20)$ & $30.2(5.39)$ \\
\hline $\mathrm{NH}_{4}{ }^{15} \mathrm{NO}_{3}$ (plants) & $422(163)$ & $33.4(8.78)$ & $1.19(0.19)$ & $27.8(4.97)$ \\
\hline $\mathrm{NH}_{4}{ }^{15} \mathrm{NO}_{3}$ & $233(83.4)$ & $26.0(7.67)$ & $0.97(0.21)$ & $26.6(4.76)$ \\
\hline${ }^{15} \mathrm{NH}_{4} \mathrm{NO}_{3}$ (plants) & $428(153)$ & $36.6(11.6)$ & $1.18(0.25)$ & $30.8(5.80)$ \\
\hline${ }^{15} \mathrm{NH}_{4} \mathrm{NO}_{3}$ & $278(127)$ & $28.5(6.75)$ & $1.06(0.27)$ & $27.2(4.22)$ \\
\hline
\end{tabular}

\subsection{4 ${ }^{15} \mathrm{~N}$ retention and recoveries in total system}

The retention of the ${ }^{15} \mathrm{~N}$ tracer in each component of the system will reflect the partitioning of ammonium- $\mathrm{N}$ and nitrate- $\mathrm{N}$ input entering the forest floor. It was detected that the proportion of labelled $\mathrm{N}$ in plants after two growing seasons in tendency was higher after ${ }^{15} \mathrm{~N}_{-} \mathrm{NO}_{3}{ }^{-}$than after ${ }^{15} \mathrm{~N}_{-\mathrm{NH}_{4}}{ }^{+}\left(17.5\right.$ vs. $15.9 \mathrm{mg} \mathrm{m}^{-2}$ ) (Table 4). Percentage recoveries of the applied ${ }^{15} \mathrm{~N}$ within the plants $\left(\right.$ total) were also higher after ${ }^{15} \mathrm{~N}_{-} \mathrm{NO}_{3}{ }^{-}$application than after ${ }^{15} \mathrm{~N}_{-} \mathrm{NH}_{4}{ }^{+}$additions (19.0 vs. $17.1 \%)$, suggests that nitrate-N additions could have a greater effect on seedlings growth than ammonium-N, although no significant differences were detected with respect to $\mathrm{NH}_{4}{ }^{+}$and $\mathrm{NO}_{3}{ }^{-}$incorporation in plants. The recovery rates of ${ }^{15} \mathrm{~N}$-ammonium and ${ }^{15} \mathrm{~N}$-nitrate in plants match well with the range of rates reported in other tracer studies (e.g. Nommik et al., 1983; Preston and Mead, 1990; Emmett and Quarmby, 1991; Mead and Preston, 1994; Buchmann et al., 1996; Nadelhoffer et al., 1995 and 1999). The average tracer recoveries of the applied ${ }^{15} \mathrm{~N}$ across both $\mathrm{N}$ forms in beech seedlings $(18.0 \%)$ revealed lower importance of seedlings as sinks for $\mathrm{N}$ inputs, as compared to forest floor $_{\text {(total) }}(23.8-21.4 \%)$. Forest floors appeared to be stronger sinks for ${ }^{15} \mathrm{~N}$ additions than were plants (Nadelhoffer et al.,1993, 1995, 1998). Comparing the retention values between the plants and forest floors in the present study indicated that the ${ }^{15} \mathrm{~N}$-ammonium in forest floor ${ }_{\text {total }}$ retained two times higher than in the plants, while the ${ }^{15} \mathrm{~N}$-nitrate retention in forest floor ${ }_{\text {total }}$ was slightly lower than that of the plants. The concentration of the ${ }^{15} \mathrm{~N}$ tracers retained in $\mathrm{O}_{\mathrm{F}}+\mathrm{O}_{\mathrm{H}}\left(1.20 \times 10^{-3}-1.03 \times 10^{-3} \mathrm{mg} \mathrm{g}^{-1}\right.$ and $0.50 \times 10^{-3}$ 
$-0.28 \times 10^{-3} \mathrm{mg} \mathrm{g}^{-1}$ ) after ${ }^{15} \mathrm{~N}$-ammonium and ${ }^{15} \mathrm{~N}$-nitrate were lower than the corresponding values in $\mathrm{O}_{\mathrm{L}}\left(0.022-0.034 \mathrm{mg} \mathrm{g}^{-1}\right.$ and $\left.0.010-0.013 \mathrm{mg} \mathrm{g}^{-1}\right)$, however, due to much higher mass the sink strength in $\mathrm{O}_{\mathrm{F}}+\mathrm{O}_{\mathrm{H}}\left(27.5-23.6 \mathrm{mg} \mathrm{m}^{-2}\right.$ after ${ }^{15} \mathrm{~N}-\mathrm{NH}_{4}{ }^{+}$to $9.88-5.88 \mathrm{mg} \mathrm{m}^{-2}$ after $\left.{ }^{15}{\mathrm{~N}-\mathrm{NO}_{3}}^{-}\right)$were significantly higher than the corresponding values in $\mathrm{O}_{\mathrm{L}}\left(4.74-7.78 \mathrm{mg} \mathrm{m}^{-2}\right.$ to $2.14-2.41 \mathrm{mg} \mathrm{m}^{-2}$ ) in the plants and non-plants treatments (Table 4). Tracer recoveries in forest floor $_{(\text {total) }}$ were significantly influenced by the form of $\mathrm{N}$ label applied. The tracer recoveries of the applied ${ }^{15} \mathrm{~N}$ retained into $\mathrm{O}_{\mathrm{L}}$ accounted for $5.09-8.36 \%$ after ${ }^{15} \mathrm{~N}$ ammonium and $2.33-2.62 \%$ after ${ }^{15} \mathrm{~N}$-nitrate, while the percentage recoveries of added ${ }^{15} \mathrm{~N}$ assimilated into $\mathrm{O}_{\mathrm{F}}+\mathrm{O}_{\mathrm{H}}$ varied between $29.5-25.4 \%$ after ${ }^{15} \mathrm{~N}-\mathrm{NH}_{4}{ }^{+}$and $10.7-6.38 \%$ after ${ }^{15}{\mathrm{~N}-\mathrm{NO}_{3}}^{-}$in plants and non-plants treatments. In consistent with Groffman et al. (1993) and Buchmann et al. (1996) more ${ }^{15} \mathrm{~N}$-ammonium was incorporated into the forest floor (total $)(32.2-$ $\left.31.4 \mathrm{mg} \mathrm{m}^{-2}\right)$ than ${ }^{15} \mathrm{~N}$-nitrate $\left(12.0-8.29 \mathrm{mg} \mathrm{m}^{-2}\right)$ in plants and non-plants treatments. This can be explained by the preference of $\mathrm{NH}_{4}{ }^{+}-\mathrm{N}$ to $\mathrm{NO}_{3}{ }^{-}-\mathrm{N}$ by soil microorganisms, followed by higher microbial immobilization of ammonium and also adsorption of $\mathrm{NH}_{4}{ }^{+}-\mathrm{N}$ through pure physicochemical reactions onto exchange sites of organic matter, while nitrate due to a lower retention capacity relative to ammonium is lost mainly into leachate (e.g. Matschonat and Matzner 1996; Aber et al. 1998). This could be seen after two growing seasons of ${ }^{15} \mathrm{~N}$ tracers application $\left(92.1-93.1 \mathrm{mg}{ }^{15} \mathrm{~N} \mathrm{~m}^{-2}\right)$, that more ${ }^{15} \mathrm{~N}$-nitrate $\left(49.1-72.8 \mathrm{mg} \mathrm{L}{ }^{-1}\right)$ than ${ }^{15} \mathrm{~N}$ ammonium $\left(21.6-31.3 \mathrm{mg} \mathrm{L}^{-1}\right)$ were incorporated into leachate (Table 5). The results of ${ }^{15} \mathrm{~N}$ retention efficiencies after ${ }^{15} \mathrm{~N}-\mathrm{NO}^{-}(46.7-21.0 \%)$ and ${ }^{15} \mathrm{~N}-\mathrm{NH}_{4}{ }^{+}(76.8-66.4 \%)$ in plants and non-plants treatments represented lower retention capacity of nitrate relative to ammonium, resulted in higher fluxes of ${ }^{15} \mathrm{~N}$-nitrate from forest floor into leachate (Table 5). The observed movement of ${ }^{15} \mathrm{~N}$ tracer through the forest floor demonstrated that although the forest floors due to high immobilization capacity were the important sink for $\mathrm{N}(23.8-21.4 \%$ of the applied $\left.{ }^{15} \mathrm{~N}\right)$, however leaching losses of the applied tracer $(38.3-56.3 \%)$ represented a significant proportion of the total $\mathrm{N}$ input. In consistent, Durka et al. (1994) indicated that the movement of ${ }^{15} \mathrm{~N}$ tracer through the forest floor corresponds well with estimates of the leaching rates of deposited nitrate. 
Table 4. The concentration $(\mathrm{mg} / \mathrm{g}$ or $\mathrm{L})$ and the amount of ${ }^{15} \mathrm{~N}$ tracer retained or leached $(\mathrm{mg}$ $\mathrm{m}^{-2}$ ) and the percentage of tracer recoveries including plant ${ }_{\text {(total) }}, \mathrm{O}_{\mathrm{L}}, \mathrm{O}_{\mathrm{F}}+\mathrm{O}_{\mathrm{H}}$ and forest floor (total) and in leachate in the ${ }^{15} \mathrm{~N}$-fertilized plants and non-plants treatments, $(n=42)$, (Standard deviation represent in parentheses).

\begin{tabular}{|c|c|c|c|c|c|c|c|}
\hline \multirow[t]{3}{*}{ pool } & \multicolumn{4}{|c|}{${ }^{15} \mathrm{~N}$ tracer retained or leached } & \multicolumn{2}{|c|}{${ }^{15} \mathrm{~N}$ tracer recovered } & \multirow{3}{*}{$\begin{array}{c}\begin{array}{c}{ }^{15} \mathrm{~N} \text { recovery } \\
(\text { mean })\end{array} \\
\%\end{array}$} \\
\hline & \multicolumn{2}{|c|}{${ }^{15} \mathrm{~N}-\mathrm{NH}_{4}{ }^{+}$} & \multicolumn{2}{|c|}{${ }^{15} \mathrm{~N}^{-\mathrm{NO}_{3}}{ }^{-}$} & ${ }^{15} \mathrm{~N}-\mathrm{NH}_{4}{ }^{+}$ & ${ }^{15} \mathrm{~N}-\mathrm{NO}_{3}^{-}$ & \\
\hline & $(\mathrm{mg} / \mathrm{g}$ or $\mathrm{L})$ & $\left(\mathrm{mg} \mathrm{m}^{-2}\right)$ & $(\mathrm{mg} / \mathrm{g}$ or $\mathrm{L})$ & $\left(\mathrm{mg} \mathrm{m}^{-2}\right)$ & & V & \\
\hline plant $_{\text {(total) }}$ & $0.034(0.03)$ & $15.9(4.18)$ & $0.042(0.04)$ & $17.5(5.28)$ & 17.1 & 19.0 & 18.03 \\
\hline $\mathrm{O}_{\mathrm{L}}$ (plants) & $0.022(0.01)$ & $4.74(2.35)$ & $0.010(0.01)$ & $2.14(0.89)$ & 5.09 & 2.33 & 3.71 \\
\hline $\mathrm{O}_{\mathrm{F}}+\mathrm{O}_{\mathrm{H}}$ (plants) & $1.20 \times 10^{-3}$ & $27.5(12.8)$ & $0.50 \times 10^{-3}$ & $9.88(6.89)$ & 29.5 & 10.7 & 20.1 \\
\hline forest floor (total) $_{\text {(plants) }}$ & & $32.2(13.0)$ & & $12.0(6.95)$ & 34.6 & 13.1 & 23.8 \\
\hline leachate (plants) & $0.041(0.02)$ & $21.6(2.71)$ & $0.079(0.03)$ & $49.1(5.42)$ & 23.2 & 53.3 & 38.3 \\
\hline $\mathrm{O}_{\mathrm{L}}$ & $0.034(0.02)$ & $7.78(6.66)$ & $0.013(0.01)$ & $2.41(1.45)$ & 8.36 & 2.62 & 5.49 \\
\hline $\mathrm{O}_{\mathrm{F}}+\mathrm{O}_{\mathrm{H}}$ & $1.03 \times 10^{-3}$ & $23.6(5.54)$ & $0.28 \times 10^{-3}$ & $5.88(2.30)$ & 25.4 & 6.38 & 15.9 \\
\hline forest floor $_{\text {(total) }}$ & & $31.4(8.66)$ & & $8.29(2.72)$ & 33.7 & 9.00 & 21.4 \\
\hline leachate & $0.051(0.01)$ & $31.3(3.21)$ & $0.098(0.02)$ & $72.8(5.57)$ & 33.6 & 79.1 & 56.3 \\
\hline
\end{tabular}

Table 5. ${ }^{15} \mathrm{~N}$ tracer input, output and retention efficiencies, the amounts of the tracer retained in plant, forest floor, and the balance values of ${ }^{15} \mathrm{~N}$ excess $\left(\mathrm{mg}^{15} \mathrm{~N} \mathrm{~m}^{-2}\right)$ and the percentage of the tracer lost in the ${ }^{15} \mathrm{~N}$-fertilized plants $(n=21)$ and non-plants $(n=21)$ treatments, (Standard deviation represent in parentheses).

\begin{tabular}{|c|c|c|c|c|c|c|c|}
\hline \multirow[t]{2}{*}{ treatment } & \multirow[t]{2}{*}{${ }^{15} \mathrm{~N}$-input } & \multirow[t]{2}{*}{${ }^{15} \mathrm{~N}$-output } & \multirow{2}{*}{$\begin{array}{c}{ }^{15} \mathrm{~N} \text { retention } \\
\text { efficiency }\end{array}$} & \multicolumn{2}{|c|}{${ }^{15} \mathrm{~N}$ tracer retained } & \multirow[t]{2}{*}{${ }^{15} \mathrm{~N}$ balance } & \multirow[t]{2}{*}{${ }^{15} \mathrm{~N}$ lost } \\
\hline & & & & plant $_{\text {(total) }}$ & forest floor $_{\text {(total) }}$ & & \\
\hline & $\left(\mathrm{mg}^{15} \mathrm{I}\right.$ & $\left.\mathrm{N} \mathrm{m}^{-2}\right)$ & $(\%)$ & $(\mathrm{m}$ & $\left.{ }^{15} \mathrm{~N} \mathrm{~m}^{-2}\right)$ & & $(\%)$ \\
\hline $\mathrm{NH}_{4}{ }^{15} \mathrm{NO}_{3}$ (plants) & $92.1(0.68)$ & $49.1(5.42)$ & 46.7 & $17.5(5.28)$ & $12.0(6.95)$ & $13.5(10.3)$ & 14.7 \\
\hline $\mathrm{NH}_{4}{ }^{15} \mathrm{NO}_{3}$ & $92.1(0.68)$ & $72.8(5.57)$ & 21.0 & - & $8.29(2.72)$ & $11.0(6.23)$ & 11.9 \\
\hline${ }^{15} \mathrm{NH}_{4} \mathrm{NO}_{3}$ (plants) & $93.1(1.24)$ & $21.6(2.71)$ & 76.8 & $15.9(4.18)$ & $32.2(13.0)$ & $23.3(14.0)$ & 25.1 \\
\hline${ }^{15} \mathrm{NH}_{4} \mathrm{NO}_{3}$ & $93.1(1.24)$ & $31.3(3.21)$ & 66.4 & - & $31.4(8.66)$ & $30.4(9.32)$ & 32.7 \\
\hline
\end{tabular}




\subsection{5 ${ }^{15} \mathrm{~N}$ budgets}

Estimating the balance values of ${ }^{15} \mathrm{~N}_{\text {(excess) }}$, as the difference between ${ }^{15} \mathrm{~N}$ input and the amounts of the tracer in leachate and the ${ }^{15} \mathrm{~N}$ retained in plants $_{(\text {total })}$ and forest floors $($ total) , indicated higher ammonium retention capacity $\left(23.3-30.4 \mathrm{mg}{ }^{15} \mathrm{~N}_{-} \mathrm{NH}_{4}{ }^{+} \mathrm{m}^{-2}\right)$ compared to nitrate (13.5

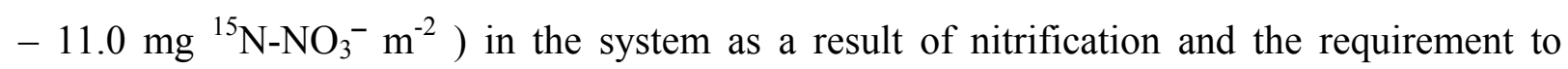
maintain a constant $\mathrm{N}$ concentration in equilibrium between $\mathrm{N}$-immobilization and mineralization (Table 5). Total recovery rates of the applied ${ }^{15} \mathrm{~N}$ in the total system accounted for $(85.3-88.1 \%)$ after ${ }^{15} \mathrm{~N}$-nitrate and $(74.9-67.3 \%)$ after ${ }^{15} \mathrm{~N}$-ammonium in plants and non-plants treatments, respectively. The labelled $\mathrm{N}$ not recovered in the investigated parts amounted to $(14.7-11.9 \%)$ after ${ }^{15} \mathrm{~N}-\mathrm{NO}^{-}$and $(25.1-32.7 \%)$ after ${ }^{15} \mathrm{~N}^{-\mathrm{NH}_{4}}{ }^{+}$in plants and non plants treatments, has presumably been lost by denitrification (Table 5). In consistent, Mochoge and Beese (1983) demonstrated losses of labelled nitrogen in forest soils in the range of 10 to $35 \%$. Melin et al. (1983) reported the rates of the labelled N lost after two growing seasons $\mathrm{NH}_{4} \mathrm{NO}_{3}$ fertilizer application in a Pinus sylvestris stand amounted to $11-31 \%$. Mulholland et al. (1999) reported total recovery of $64-79 \%$ of the applied ${ }^{15} \mathrm{~N}$ after six weeks ${ }^{15} \mathrm{~N}$-labelled ammonium addition in a first-order deciduous forest stream. Our data further exhibited that the losses after ${ }^{15} \mathrm{~N}_{-} \mathrm{NH}_{4}{ }^{+}$addition were up to 2.7 times higher than after ${ }^{15} \mathrm{~N}$ $\mathrm{NO}_{3}{ }^{-}$application. This may presumably due to the transport behaviour of these ions in the forest floor. The anionic nitrate which did not interact with the organic matter, was leached out much faster than the cationic ammonium. Consequently, there was not enough time for further $\mathrm{NO}_{3}{ }^{-}$transformations as was the case for $\mathrm{NH}_{4}{ }^{+}$. Nitric oxide is the main gaseous component when nitrate is added to acidic forest humus. Production of nitric oxide (NO) can occur during both nitrification and denitrification (Galbally 1989, Davidson et al. 1993), but net losses via this avenue and other potential pathways of gaseous $\mathrm{N}$ loss are not well quantified for temperate forests. Wolf and Brumme, (2003) showed that under natural conditions a moder humus, Solling, is a source of $\mathrm{N}_{2}$. Due to acidic forest floor conditions it seems unlikely that any amounts of labelled $\mathrm{N}$ could have been lost from the system through volatilization of $\mathrm{NH}_{3}$. Whether the losses were caused by biological processes or in combination with abiotic processes still is unknown. However, under high biological oxygen demand, the rate of $\mathrm{O}_{2}$ diffusion to facultative denitrifiers may become limiting even under unsaturated water regimes (Reddy and Patrick, 1975). In the present study it is likely that high soil water content (mean $138.7 \%$ of dry weight) by reducing the oxygen availability may provide conditions, where the microenvironments of the soil microbes may become anaerobic which promote the 
denitrification of N (Stanford et al., 1975; Alexander, 1977). The quantities of gaseous N exchange and the mechanisms responsible for gaseous evolution are a complex combination of environmental and substrate conditions that control mineralization of $\mathrm{N}$ as well as subsequent nitrification and denitrification.

\subsection{Conclusion}

The results of the present study demonstrated that the applied nitrogen in plant available forms to a lower extent is taken up directly by the plants leading to an immobilization via the litter and forest floor $\mathrm{O}_{\mathrm{F}}+\mathrm{O}_{\mathrm{H}}$. The preferential heterotrophic use of ammonium resulted in a two times higher retention of deposited ${ }^{15} \mathrm{NH}_{4}$ in the forest floor compared to plants. In contrast, the nitrate immobilization in the forest floor was lower compared to plants although statistically not significantly different. The form of $\mathrm{N}$ input influenced its movement into plant pools. It was demonstrated that beech seedlings take up nitrogen mainly in the form of nitrate, which is then reduced in the leaves, although the differences between the retention of $\mathrm{NO}_{3}-\mathrm{N}$ and $\mathrm{NH}_{4}-\mathrm{N}$ in plants were not statistically significant. In addition the results showed that the percentage recoveries of ${ }^{15} \mathrm{~N}$ retained in the forest floor were 3 times higher when ${ }^{15} \mathrm{NH}_{4}{ }^{+}$was applied as compared to ${ }^{15} \mathrm{NO}_{3}{ }^{-}$. Because ${ }^{15} \mathrm{~N}_{-} \mathrm{NH}_{4}{ }^{+}$and ${ }^{15} \mathrm{~N}_{-} \mathrm{NO}_{3}{ }^{-}$in equivalent amounts were applied the presented results can be used to determine how forms and rates of the $\mathrm{N}$-inputs affects the distribution of nitrogen into different components of the system. It was evident that not the plants but the microorganisms can responsible for a substantially higher retention of $\mathrm{NH}_{4}^{+}$than $\mathrm{NO}_{3}{ }^{-}$in the total system plant-soil. In general the immobilization of ammonium in the plantsoil system was about $60 \%$ higher than for nitrate and indicated the importance of the $\mathrm{N}$-forms deposition for the retention in forest ecosystems. 


\section{Summary}

The mechanisms of carbon and nitrogen transformation in forest ecosystems are important for the element cycling in forest ecosystems. Most forests in Germany have moder and mor humus forms which is why most of the element cycling in acid soils proceed in the forest floor. The quality of the forest floor is also assumed to be responsible for the retention of deposited nitrogen but there is a controversial discussion about the capacity of the forest floor to adsorb deposited nitrogen. Nitrogen deposition in forest ecosystems is of concern because of nitrate leaching and $\mathrm{N}_{2} \mathrm{O}$ emissions, also $\mathrm{N}_{2} \mathrm{O}$ is a greenhouse gas and has the ability to destroy the ozone layer in the stratosphere. Most forest ecosystems actually indicate a high ability to immobilize deposited nitrogen. The presented work contributes to the discussion regarding the function of the forest floor in the carbon and nitrogen transformation of forest ecosystems. Two experiments were conducted. Undisturbed cores from the forest floor of a beech (Fagus silvatica), a spruce (Picea abies) and a mixed tree forest (beech and spruce) at the Solling, Germany, were incubated at $1,5,10,15$, and $20^{\circ} \mathrm{C}$ to study the net $\mathrm{C}$ mineralization, net $\mathrm{N}$-mineralization, and $\mathrm{N}_{2} \mathrm{O}$ emission (see Figure 1). In a second experiment (see Figure 2) the same forest floors were incubated with beech seeds over a period of 442 days to study the influence of trees on the carbon and nitrogen cycling. It was hypothesized:

I. that the forest floors of spruce stands show a higher degree of N-saturation with higher $\mathrm{C}: \mathrm{N}$ ratio, increased net $\mathrm{N}$-mineralization $(\mathrm{NNM})$ and losses via nitrate leaching and $\mathrm{N}_{2} \mathrm{O} / \mathrm{NO}$ emissions.

II. that $\mathrm{N}$ immobilization in the forest floor from atmospheric $\mathrm{N}$ deposition increases the $\mathrm{NNM}$ and $\mathrm{N}_{2} \mathrm{O}$ losses at elevated temperatures indicated by higher $\mathrm{Q}_{10}$ values compared to net $\mathrm{C}$ mineralization (NCM).

III. based on the hypothesis of Aber et al (1998), mycorrhizal fine roots improve the $\mathrm{N}$ immobilization without increased $\mathrm{CO}_{2}$ emissions.

IV. that the applied nitrogen in plant available forms to a lower extent is taken up directly by the plants leading to an immobilization via the litter and forest floor.

V. that ammonium is preferred by microorganisms in contrast to plants, resulted in higher total retention in the soil-plant system when this $\mathrm{N}$ form is applied. 
I. A parameter to characterize the degree of $\mathrm{N}$ saturation of a forest ecosystem is the $\mathrm{C} / \mathrm{N}$ ratio of the forest floor. A higher $\mathrm{N}$ deposition in spruce forests, primary resulted from a higher dry deposition, was assumed to have reduced $\mathrm{C} / \mathrm{N}$ ratio in the forest floor to a larger extend than in the beech stand. Low $\mathrm{C} / \mathrm{N}$ ratios in all three stands (beech, spruce, and mixed forest) indicated that high $\mathrm{N}$ deposition has increased the $\mathrm{N}$ content independent of the plant species. Moreover, all soil chemical properties of the forest floors did not show any significant difference. Net N-mineralization, studied in the first experiment (see Figure 1), often observed to be higher in beech than in spruce forest soils, was similar and correspond with a uniform microbial biomass and ergosterol content, an indicator for fungal biomass.

II. The temperature dependence of biological processes, studied in the first experiment (see Figure 1), is generally be characterized by doubling or tripling if the temperature increases by $10^{\circ} \mathrm{C}\left(\mathrm{Q}_{10}=2-3\right)$. Incubation studies at $1,5,10,15$, and $20^{\circ} \mathrm{C}$ revealed a similar increase in NCM and NNM in the forest floor of the beech, spruce and mixed species forests. The higher $\mathrm{Q}_{10}$ value for NNM was not significantly different to NCM. Higher $\mathrm{Q}_{10}$ value for $\mathrm{N}_{2} \mathrm{O}$ than for $\mathrm{NNM}$ is well known from the literature and is rather explained by positive feed back mechanisms than by $\mathrm{N}$ saturation. At $20^{\circ} \mathrm{C}$, a temperature which normally not affected the soils at Solling, a drastic change in the microbial community was observed. The microbial biomass was about 50\% lower compared to the lower temperatures although the mineralization followed the exponential temperature increase and indicated a higher specific respiration $\left(\mathrm{NCM} \mathrm{g}^{-1} \mathrm{C}_{\text {mic }}\right.$ ) at $20^{\circ} \mathrm{C}$. Resulting from a moderate decrease in fungal biomass, which was higher at the beech stand than at the spruce stand, the decrease in microbial biomass was primary attributed to a decrease in bacterial biomass.

III. $\mathrm{N}$ immobilization by roots was studied in the second experiment (see Figure 2). immobilization of deposited ${ }^{15} \mathrm{~N}$ labeled nitrogen by mycorrhizal roots may increase the ${ }^{15} \mathrm{~N}$ sequestration by their turnover which may be detectable in the soil organic matter. A higher ${ }^{15} \mathrm{~N}$ content in the forest floor with beech seedlings indicated that plants may have improved the $\mathrm{N}$ immobilization. Different forest floor material seems to have no effect on $\mathrm{N}$ immobilization. However, a high $\mathrm{N}$ stock and high spatial variability in the forest floors have prevented a statistically significant result. 
IV. The plant uptake of nitrogen was similar between the control and ${ }^{15} \mathrm{~N}$-fertilized treatments and showed statistically insignificant differences in the uptake of nitrate and ammonium (second experiment, Figure 2). Most of the ${ }^{15} \mathrm{~N}$ taken up by the plants was used to build up the above ground seedling (one-third of total plant uptake) and the coarse roots (onethird of total plant uptake). Fine roots account for less than one-fourth. The ${ }^{15} \mathrm{~N}$ transfer to the forest floor via leaves in the second year, which were collected in autumn to prevent a ${ }^{15} \mathrm{~N}$ flux via litter fall, was less than $5 \%$ at the end of the experiment. Although this flux is of less importance annually it may be a very important pathway of deposited nitrogen to the forest floor in the long-term.

V. Nitrogen immobilization by heterotrophic microorganisms in the forest floor was three times higher after ammonium than after nitrate (second experiment, Figure 2). The preferential heterotrophic use of ammonium resulted in a two times higher retention of deposited ${ }^{15} \mathrm{~N}$ in the forest floor compared to plants. In contrast, the nitrate immobilization in the forest floor was lower compared to plants although statistically not significantly different. In total the immobilization of ammonium in the plant-soil system was about $60 \%$ higher than for nitrate and indicated the importance of the $\mathrm{N}$-forms deposition for the retention in forest ecosystems. 


\section{Zusammenfassung}

Das Verständnis der Mechanismen der Kohlenstoff- und Stickstoffumsetzungen im Boden sind von großer Bedeutung für den Elementkreislauf und die Ernährung von Waldökosystemen. Die überwiegende Teil der Waldböden in Deutschland ist stark versauert und durch die Ausbildung von Moder- und Rohhumusformen erfolgen die Stoffumsetzungen im Wesentlichen im Auflagehumus. Die Qualität des Auflagehumus ist weiterhin entscheidend für die Fähigkeit von Waldökosystemen den eingetragenen Stickstoff zu immobilisieren, während die Frage nach der Retentionskapazität von Humusauflagen weiterhin umstritten ist. Die Stickstoffdepositonen in Waldökosysteme können zu einer starken Belastung von angrenzende Ökosystemen führen, wenn die Retentionskapazitäten erschöpft sind. Die Folge sind erhöhte Nitratausträge und Lachgasemissionen, ein Gas das zum Treibhauseffekt beiträgt und an der katalytischen Zerstörung der Ozonschicht beteiligt ist. Die vorliegenden Arbeit leistet einen Beitrag zur Funktion der organischen Auflagen im Kohlen- und Stickstoffkreislauf von Waldökosystemen. Dazu wurden zwei Experimente durchgeführt. In einem Ansatz wurde die Temperaturabhängigkeit des Netto C-Mineralisation (NCM), Netto N-Mineralisation (NNM) und der $\mathrm{N}_{2} \mathrm{O}$ Emissionen durch Inkubation bei 1, 5, 10,15 und $20^{\circ} \mathrm{C}$ studiert (siehe Abbildung 1). Als Probenmaterial wurde ein Kollektiv von ungestörten Humusauflagen aus drei benachbarten Versuchsflächen im Solling verwendet. Es handelte sich um einen mullartigem Moder unter den Hauptbaumarten Fichte (Picea abies), Buche (Fagus sylvatica) und um einen Fichten-Buchen-Mischbestand. In einem zweiten Versuch (siehe Abbildung 2) wurden die gleichen Humusauflagen mit Buchensamen über einen Zeitraum von 442 Tagen bei konstanter Temperatur inkubiert, um den Einfluß der Jungpflanzen auf dem Kohlenstoff- und Stickstoffumsatz zu studieren. Für das Studium der N-Transformationsprozesse in der Pflanze und den Humusauflagen wurde das Stickstoffisotop ${ }^{15} \mathrm{~N}$ eingesetzt.

Es wurde folgende Hypothesen überprüft:

I. Die Humusauflage des Fichtenstandortes weisen einen höheren Grad an N-Sättigung auf der sich durch eine höheres C:N verhältnis, eine erhöhte NNM, Nitratauswaschung und $\mathrm{N}_{2} \mathrm{O}$ Emission bemerkbar macht. 
II. Eine erhöhter Grad der N-Sättigung führt zu einer größeren Temperaturabhängigkeit der $\mathrm{NNM}$ und der $\mathrm{N}_{2} \mathrm{O}$ Emissionen und damit zu höheren $\mathrm{Q}_{10}$ Werten im Vergleich zur NCM.

III. Basierend auf der Hypothese von Aber et al. (1998) wird die N-Immobilisation durch mykorrhizierte Feinwurzeln erhöht ohne eine erhöhte $\mathrm{CO}_{2}$ Emission zu verursachen.

IV. Ein Teil des deponierten Stickstoff wird direkt von Pflanzen aufgenommen und in den Pflanzen immobilisiert oder durch Streufall den Humusauflagen zugeführt.

V. Ammonium wird bevorzugt von Mikroorganismen aufgenommen im Gegensatz zu Pflanzen was zu einer erhöhten Gesamtimmobilisation im System Boden/Pflanze führt wenn überwiegend Ammonium in Waldökosysteme eingetragen wird.

I. Ein Parameter, den Grad von N Sättigung eines Waldökosystems zu charakterisieren, ist das $\mathrm{C} / \mathrm{N}$ Verhältnis des Waldbodens. Eine höhere N Deposition in Fichtewälder, vor allem bedingt durch eine erhöhte trockenen Deposition, könnte zu einem engeren $\mathrm{C} / \mathrm{N}$ Verhältnis in Humusauflagen von Fichtenwäldern geführt haben. Niedrige $\mathrm{C} / \mathrm{N}$ Verhältnisse in allen drei untersuchten Humusauflagen deuten jedoch darauf hin, dass die über mehre Dekaden erfolgten hohen N Deposition in allen Systemen zu einer NSättigung geführt haben. Darüber hinaus zeigten alle chemischen Eigenschaften der Humusauflagen keinen bedeutenden Unterschied auf. Auch die NNM, untersucht im 1. Experiment, wies keinen Unterschied zwischen den Humusauflagen auf und kann zum Teil auf eine einheitliche mikrobielle Biomasse und Ergosterolgehalt, ein Maß für die pilzliche Biomasse, zurückgeführt werden.

II. Die Temperaturabhängigkeit von biologischen Prozesse, studiert im 1. Experiment, ist im allgemeinen durch eine Verdoppeln oder Verdreifachung der Raten bei einer Temperaturerhöhung von $10^{\circ} \mathrm{C}$ gekennzeichnet, angegeben durch den $Q_{10}$ Wert $\left(Q_{10}=2\right.$ - 3). Die Inkubation bei $1,5,10,15$ und $20^{\circ} \mathrm{C}$ führte in allen Humusauflagen zu einer Zunahme der NNM und NCM. Der etwas höhere $Q_{10}$ Wert für die NNM im Vergleich zur NCM war statistisch nicht abzusichern. Der wesentlich höhere $Q_{10}$ Wert für die $\mathrm{N}_{2} \mathrm{O}$ Emission wird in der Regel nicht auf eine erhöhte N-Sättigung sondern auf andere positive Rückkopplungsmechanismen zurückgeführt, die in dieser Arbeit nicht gesondert 
untersucht wurden. Die Inkubation bei $20^{\circ} \mathrm{C}$, eine Bodentemperatur die im Solling normalerweise nicht erreicht wird, hat $\mathrm{zu}$ einer drastischen Veränderung in der mikrobiellen Biomasse und Zusammensetzung geführt. Die mikrobielle Biomasse war ungefähr $50 \%$ niedriger im Vergleich $\mathrm{zu}$ den niedrigen Temperaturen in den Humusauflagen der 3 Standorte, obwohl die Mineralisation dem exponentiellen Temperaturanstieg folgte. Dies ist auf eine höhere spezifische Atmung (NCM g-1 $\mathrm{C}_{\text {mic }}$ ) bei $20^{\circ} \mathrm{C}$ zurückzuführen. Diese Veränderung geht einher mit einer moderaten Reduktion der pilzlichen Biomasse in den Humusauflagen des Buchenstandortes, ist aber vor allem auf eine starke Reduktion der bakteriellen Biomasse zurückzuführen.

III. Die Stickstoff Immobilisation durch Wurzeln wurde im 2. Versuch untersucht (siehe Abbildung 2). Die Immobilisierung von ${ }^{15} \mathrm{~N}$ markiertem Stickstoffes durch mycorrhizierte Wurzeln kann die Retention von deponiertem Stickstoff durch den Umsatz derselben erhöhen und in der organischen Auflage gespeichert werden. Durch Isotopenuntersuchungen kann der Nachweis der Immobilisation erfolgen. Ein höhere ${ }^{15} \mathrm{~N}$ Retention in den Humusauflagen mit Buchensämlingen zeigte an, dass Pflanzen die N Immobilisierung im Boden verbessert haben. Es wurden keine Unterschiede zwischen den Humusauflagen festgestellt. Jedoch konnten die Ergebnisse aufgrund einer hohen räumliche Variation der N Mengen in den Humusauflagen bei gleichzeitig sehr hohen N Vorräten nicht statistisch abgesichert werden.

IV. Das Pflanzenaufnahme von markiertem Stickstoff unterschied sich nicht zwischen den Arten und es konnten auch keine statistisch gesicherten Unterschiede bei der Aufnahme von ${ }^{15} \mathrm{~N}$ markiertem Ammonium und Nitrat festgestellt werden. Der größte Teil des aufgenommen ${ }^{15} \mathrm{~N}$ wurde für den Aufbau der oberirdischen Biomasse und der Hauptwurzeln verwendet (je, ein Drittel des gesamte Stickstoff Aufnahme). Feinwurzeln erklären weniger als ein Viertel der gesamten N Aufnahme. Die Anteil, der über Blätter dem Auflagehumus im zweiten Jahr potentiell hätte zugeführt werden können (Blätter wurden vor dem Laubfall gesammelt um den Fluß zu unterbinden) war kleiner als 5\% der gesamten N-Aufnahme am Ende des Versuchs. Obwohl der jährlich Fluß keine große Bedeutung hat, kann er langfristig zu einer für das Waldökosystem wichtigen Speicherung im Auflagehumus führen. 
V. Die heterotrophe Immobilisation durch Mikroorganismen in der Humusauflage war 3 mal höher für Ammonium als für Nitrat (2.Experiment, Abbildung 2). Die bevorzugte heterotrophe Immobilisation von Ammoniums hat $\mathrm{zu}$ einer 2 mal höherer Retention von gespeichertem ${ }^{15} \mathrm{~N}$ in den Humusauflagen im Vergleich zu den Pflanzen geführt. In Gegensatz dazu war die Nitratimmobilisierung in der Humusauflage niedriger verglichen zu den Pflanzen, obwohl statistisch nicht verschieden. Insgesamt war die Immobilisieung des Ammoniums im Pflanze/Boden System ungefähr 60\% höher als für Nitrat, und weist auf die Bedeutung der N-Formen bei der Immobilisation in Waldökosystemen hin. 


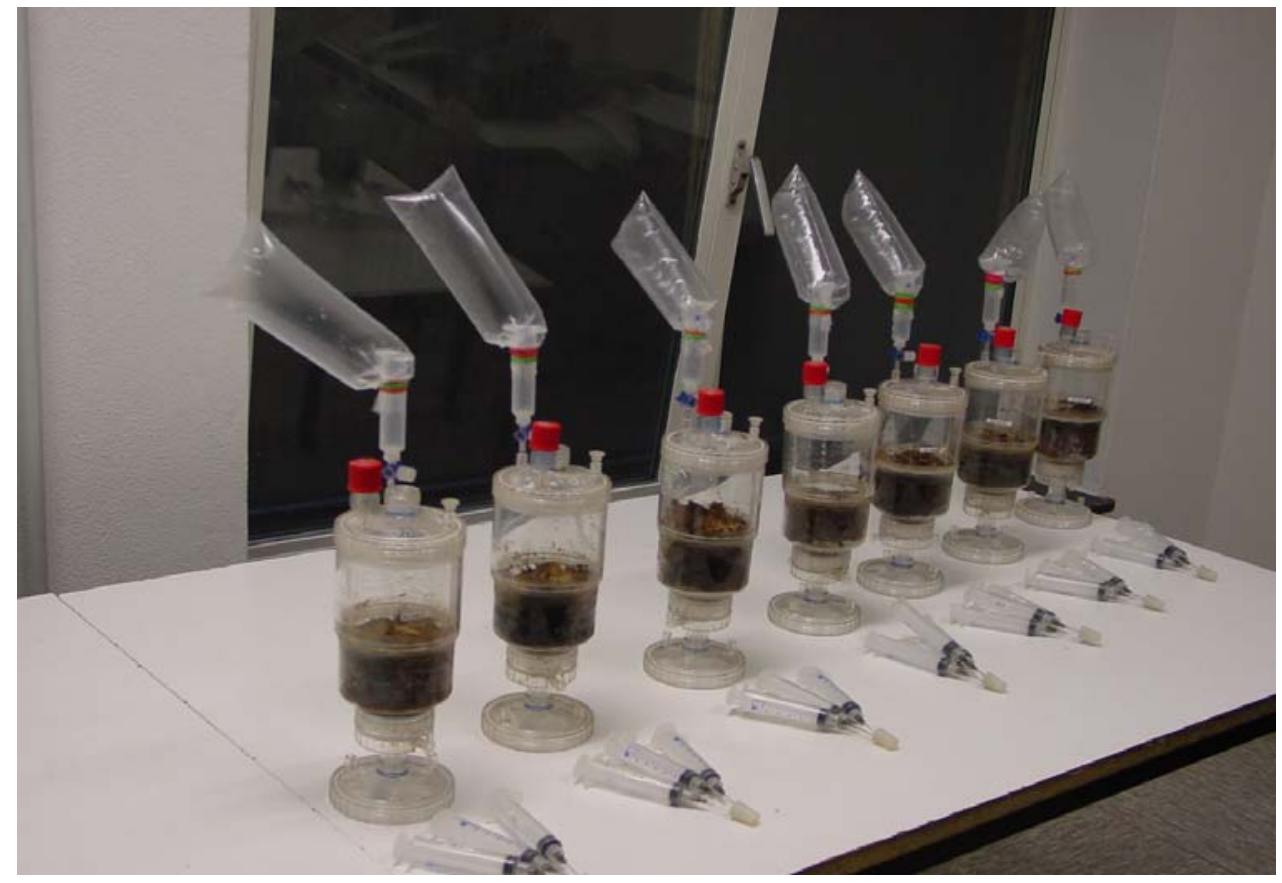

Figure 1. Forest floor samples of the incubation experiment.

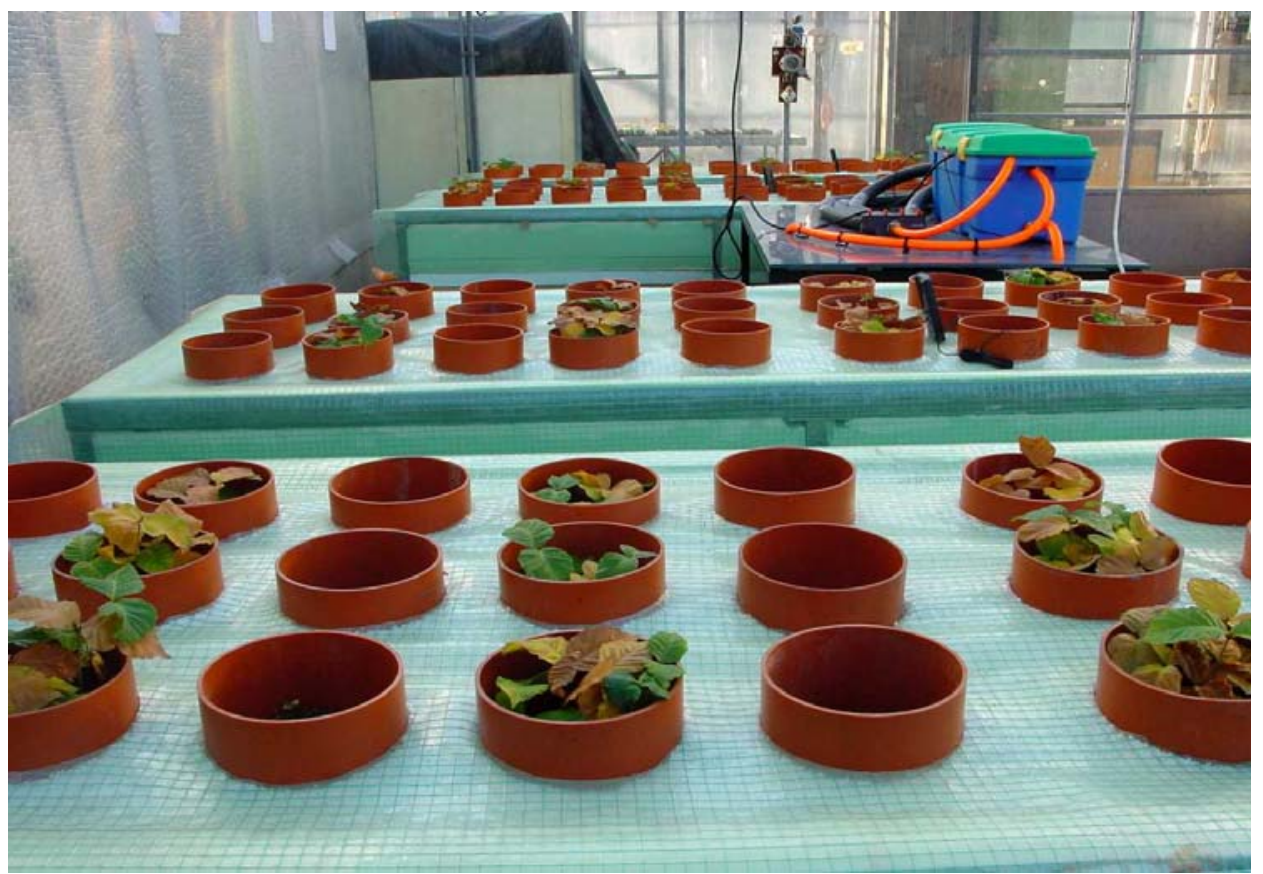

Figure 2. Greenhouse experiment. 

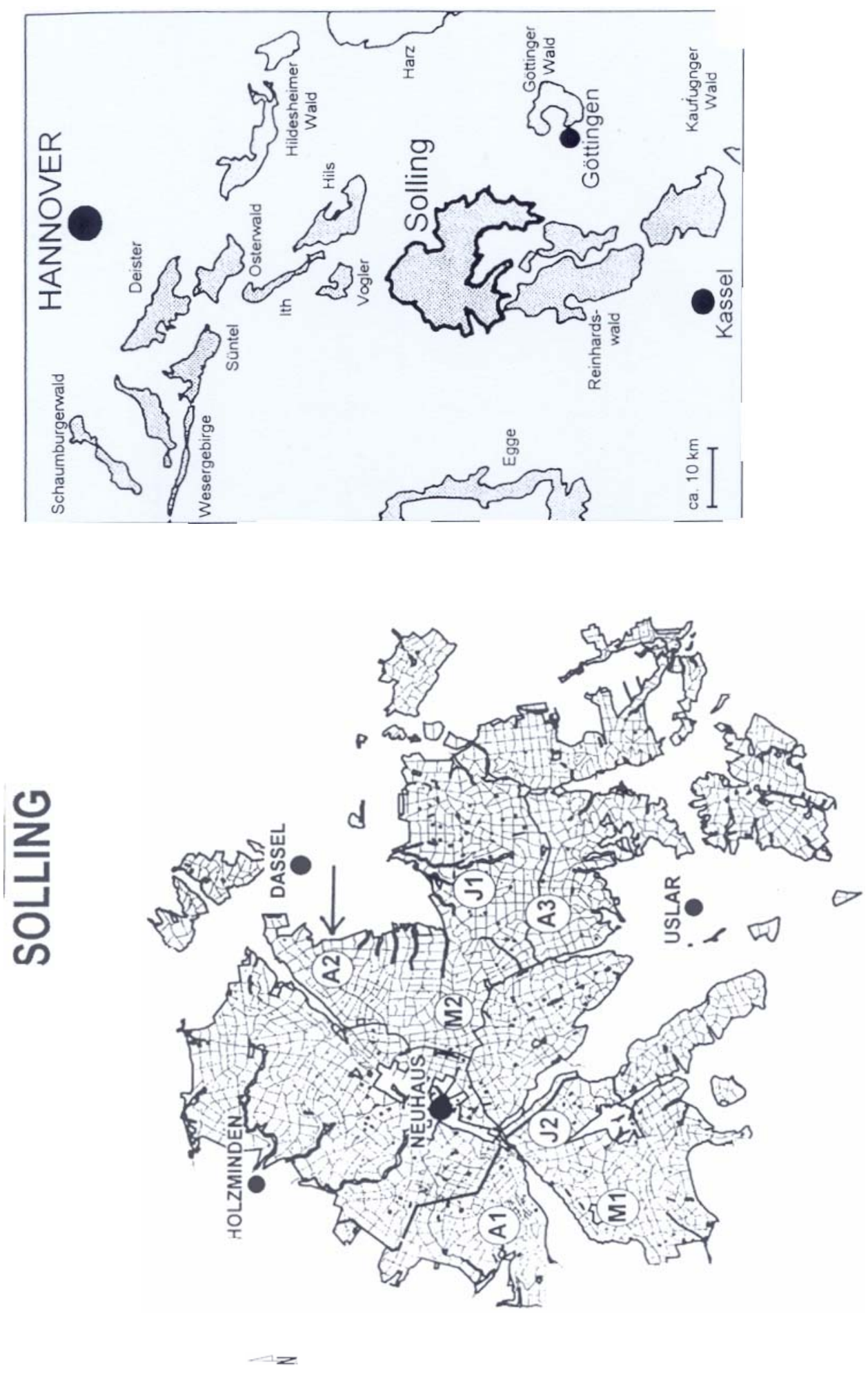

Position of the Solling forest and the location of the sampling sites (A2) in Solling. 


\section{References}

Aber, JD., McDowell, WH., Nadelhoffer, KJ., Magill, A. Berntson, G. Kamakea, M., McNulty, SG., Currie, W., Rustad, L. and Fernandez, I. 1998. Nitrogen saturation in temperate forest ecosystems. Hypotheses revisited. Bio Science. 48, 921 - 934.

Aber, J. D., Melillo, J. M. and McClaugherty. C. A. 1990. Predicting long-term patterns of mass loss, nitrogen dynamics, and soil organic matter formation from initial fine litter chemistry in temperate forest ecosystems. Canadian Journal of Botanny. 68, 2201 - 2208.

Aber, J.D., Magill, A.H. Boone, R., Melillo, J.M., Steudler, P. and Bowden, R. 1993. Plant and soil responses to chronic nitrogen additions at the harvard Forest, Massachusetts. Ecological applications. 3, $156-166$.

Aber, JD., Nadelhoffer, KJ, Steudler, P., Melillo, JM. 1989. Nitrogen saturation in northern forest ecosystems. Bio Science. 39, 378 - 386.

Aber, JD. 1992. Nitrogen cycling and nitrogen saturation in temperate forest ecosystems. Trends in Ecology and Evolution. 7, 220 - 223.

Aber, JD., Melillo, JM., Nadelhoffer, KJ., Pastor, J., and Boone, RD. 1991. Factors controlling nitrogen cycling and nitrogen saturation in northern temperate forest ecosystems. Ecological Applications. 1, 303 - 315.

Alban, D.H. 1982. Effects of nutrient accumulation by aspen, spruce, and pine on soil properties. Soil Science Society of America Journal 46, 853 - 861.

Alexander, M. 1977. Introduction to soil microbiology. J. Wiley and Sons, Inc., New York and London.

Allgemeine Forst Zeitschrift (AFZ). 1995 (17), 10 Jahre Waldkalkung, 928 - 949.

Anderson JM 1988. Spatiotemporal effects of invertebrates on soil processes. Biology and Fertility of Soils 6, $216-227$

Anderson, J.M., 1991. The effects of climate change on decomposition processes in grassland and coniferous forests. Ecological Applications. 1, 326 - 347. 
Anderson, H. 2004. Soil Impacts on Microbial Biomass Carbon in Lower Saxony of Germany. Functioning and Management of European Beech Ecosystems. Editors: Brumme, R. and Khanna, P. 2004. Springer Verlag.

Anderson, J.M. 1992. Responses of soils to climate change. Advances in Ecological Research. $22,163-210$.

Arnebrant, K., and Söderström, B. 1992. Effects of different fertilizer treatments on ectomycorrhizal colonization potential in two Scots pine forests in Sweden. Forest Ecology and Management. 53, 77 - 89.

Beese, F. 1986. Parameter des Stickstoffumsatzes in Ökosystemen mit Böden unterschiedlicher Acidität. Göttinger Bodenk Ber. 90, 344.

Berg,B.,Meentemeyer,V.2002. Litter quality in a north European transect versus carbon storage potential. Plant and Soil. 242, 83 - 92.

Binkley D, Valentine D 1991. Fifty-year biogeochemical effects of green ash, white pine, and Norway spruce in a replicated experiment. Forest Ecology and Management. 40, 13 - 25.

Blagodatskaya, EV., Anderson, TH. 1998. Interactive effects of $\mathrm{pH}$ and substrate quality on the fungal-to-bacterial ratio and $q \mathrm{CO}_{2}$ of microbial communities in forest soils. Soil Biology and Biochemistry. 30 (10-11): 1269 - 1274.

Bonan, GB., Van Cleve, K. 1991. Soil temperature, nitrogen mineralization, and carbon source-sink relationships in boreal forests. Canadian Journal of Forest Research.22, 629 - 639.

Bowden, R.D., Melillo, J.M., Steudler, P.A., and Aber, J.D. 1991. Effects of nitrogen additions on annual nitrous oxide fluxes from temperate forest soils in the North eastern United States. Journal of Geophysical Research. 96 (D5), 9321 - 9328.

Boxman, A.W., Van Dam, D., Van Dijk, H.F.G., Hogervorst, R.F. and Koopmans, C.J. 1995. Ecosystem responses to reduced nitrogen and sulfur inputs to two coniferous stands in the Netherlands. Forest Ecology and Management. 71, 7 - 30.

Brown, AHF 1992. Functioning of mixed-species stands at Gisburn NW England. In: Cannell 
MGR, Malcolm DC, Robertson PA (eds) The ecology of mixed species stands of trees.

Blackwell, Oxford, pp 125 - 150.

Brookes, P.C., Landman, A., Pruden, G., and Jenkinson, D.S. 1985. Chloroform fumigation and the release of soil nitrogen. Soil Biology and Biochemistry. 17, 837 - 842.

Bredemeier, M., Blanck, K., and Lamersdorf. N. and Wiedey, G.A. 1995. Response of soil water chemistry to experimental "clean rain" in the NITREX roof experiment at Solling, Germany. Forest Ecology and Management. 71, 31 - 44.

Brumme, R., Egenolf, M., Wolff, B., Riek, W., Baritz, R. 2004. Stocks and changes of Carbon and Nitrogen of German Forest Soils. Functioning and Management of European Beech Ecosystems. Editors: Brumme, R. and Khanna, P. 2004. Springer Verlag.

Brumme, R., Borken, W., Finke. S. 1999. Hierarchical control on $\mathrm{N}_{2} \mathrm{O}$ emissions in forest ecosystems. Global Biogeochemical Cycles. 13, 4, 1137 -- 1148.

Brumme, R., 1995. Mechanisms of carbon and nutrient release and retention in beech forest gaps,III. Environmental regulation of soil respiration and nitrous oxide emissions along a microclimatic gradient. Plant and Soil. 168-169, 593 - 600.

Brumme, R. and Beese, F. 1992. Effects of liming and nitrogen fertilization on emissions of $\mathrm{CO}_{2}$ and $\mathrm{N}_{2} \mathrm{O}$ from a temperate forest. Journal of Geophysical Research. 97, 12851 - 12858.

Buchmann, N., Gebauer, G., Schulze, E.D. 1996. Partitioning of ${ }^{15} \mathrm{~N}$-labeled ammonium and nitrate among soil, litter, below- and above-ground biomass of trees and understory in a 15year-old Picea abies plantation. Biogeochemistry. 33, 1 - 23.

Buberl, HG., v. Wilpert, K., Trefz-Malcher, G., Hildebrand, EE., Wiebel, M. 1994. Der chemische Zustand von Waldböden in Baden-Württemberg. Mitteilungen der Forstlichen Versuchs- und Forschungsanstalt Baden-Württemberg, Heft 182.

Canham, C.D.,Berkowitz, A.R., Kelly, V.R., Lovett, G.M., Ollinger, S.V., and Schnurr, J.1996. 
Biomass allocation and multiple resource limitation in tree seedlings. Canadian Journal of Forest Research. 26, 1521 - 1530.

Cannell, M.G.R. 1985. Dry-matter partitioning in tree crops.- In Attributes of Trees as Crop plants (M.G.R. Canell and J.E. Jackson, eds), pp. 160-193. Institue of Terrestrial Ecology, Huntingdon. ISBN 0-904282-83-X.

Cicerone, R. J., Changes in stratospheric ozone, 1987. Science, 237, 35-42.

Cromer, R.N. and Jarvis, P.G. 1990. Growth and biomass partitioning in Eucalyptus grandis seedlings in response to nitrogen supply. Aust. Journal of Plant Physiology. 17, 503 - 515.

Currie, W.S., Aber, JD., McDowell, WH., Boone, RD., and Magill, AH., 1996. Vertical transport of dissolved organic $\mathrm{C}$ and $\mathrm{N}$ under long-term $\mathrm{N}$ amendments in pine and hard-wood forests. Biogeochemistry. 35, 471 - 505.

Davidson, E.A., Matson, P.A., Vitousek, P.M., Riley, R., Dunkin, K., Garcia-Mendez, G., and Maass, J.M. 1993. Processes regulating soil emissions of $\mathrm{NO}$ and $\mathrm{N}_{2} \mathrm{O}$ in a seasonally dry tropical forest. Ecology. 74, 130 - 139.

Davidson, E.A., Myrold, D.D. and Groffman, P.M. 1990. Denitrification in temperate forest ecosystems. Pages 196-220. Sustained productivity of forest soils. Faculty of Forestry publications. University of British Colombia, Vancouver, Canada.

Dise, NB., and Wright, RF. 1995. Nitrogen leaching in European forests in relation to nitrogen deposition. Forest Ecology and Management. 71, 153 - 162.

Djajakirana, G., Joergensen, R.G., Meyer, B. 1996. Ergosterol and microbial biomass relationship in soil. Biology and fertility of soils. 22, $299-304$.

Dohrenbusch, A., 1990. Verjüngungsentwicklung der Buche (Fagus sylvatica L.): Bericht einer langfristigen Beobachtung im Sollingen. Schriften aus der Forstliche Fakultät der Universität Göttingen, Bd 97. Sauerländer, Frankfurt am Main, 70 pp. 
Durka, W., Schulze, ED., Gebauer, G. and Voerkelius, S. 1994. Effects of forest decline on uptake and leaching of deposited nitrate determined from ${ }^{15} \mathrm{~N}$ and ${ }^{18} \mathrm{O}$ measurements. Nature. $372,765-767$.

Ellenberg, H., Mayer, R., Schauermann, J. 1986. Ökosystemforschung- Ergebnisse des Sollingprojekts 1966 - 1986. Stuttgart: Ulmer, 1986.

Emmet, BA., Quarmby, C. 1991. The effect of harvesting intensity on the fate of applied ${ }^{15} \mathrm{~N}-$ ammonium to the organic horizons of a coniferous forest in N-Wales.Biogeochemistry.15, 47 63.

Emmer, IM., and Tietema, A. 1990. Temperature-dependent nitrogen transformation in acid oak-beach forest litter in the Netherlands. Plant and Soil. 122, 193 - 196.

Evans, J. R. 1989. Photosynthesis and nitrogen relationships in leaves of $\mathrm{C}_{3}$ plants. Oecologia. 78, $9-19$.

Fernandez I J and Struchtemeyer R A.1984. Correlation between element concentrations in spruce foliage and forest soils. Commun. Soil Science and Plant Anal. 15, 1243 - 1255.

Ferrari, J. B. 1999. Fine-scale patterns of leaf litterfall and nitrogen cycling in an old-growth forest. Canadian Journal of Forest Research. 29, 291 - 302.

Flanagan, PW., Van Cleve, K.1983. Nutrient cycling in relation to decomposition and organic matter quality in taiga ecosystems. Canadian Journal of Forest Research. 13, 795 - 817.

Foster, NW., Beauchamp, EG., Corke, CT. 1980. Microbial activity in Pinus banksiana Lamb. Forest floor amended with nitrogen and carbon. Canadian Journal of Soil Science. 60, 199 209.

Galbally, I.E. 1989. Factors controlling Nox emissions from soils. Pages 23 - 37 in M. O. Andreae and D. S. Schimel, editors. Exchange of trace gases between terrestrial ecosystems and the atmosphere. John Woley and Sons, Chichester, England.

Geßler, A., Schneider, S., Sengbusch, D., Weber, P., Hanemann, U., Huber, C., Rothe, A., Kreutzer, K., Rennenberg, H. 1998. Field and laboratory experiments on net uptake of nitrate and ammonium by the roots of Spruce (Picea abies) and Beech (Fagus sylvatica) Trees. New Phytologist.138, 275 - 285. 
Glatzel, G., Kazda, M. 1985. Wachstum und Mineralstoffernährung von Buche (Fagus sylvatica) und Spitzahorn (Acer plantanoides) auf versauertem und schwermetallbelatetem

Bodenmaterial aus dem Einsickerungsberich von Stammabflußwasser in Buchenwäldern. Zeitschrift für Pflanzenernährung und Bodenkunde. 148, 429 - 438.

Goncalves, JLM., Caryle, JC. 1994. Modelling the influence of moisture and temperature on net nitrogen mineralization in a forested sandy soil. Soil Biology and Biochemistry. 26, 1557 1564 .

Gower ST, Son Y 1992. Differences in soil and leaf litterfall dynamics for five forest plantations. Soil Science Society of America Journal. 56, 1959 - 1966.

Groffman, PM., Zak, DR., Christensen, S., Mosier, A., and Tiedje, JM. 1993. Early spring nitrogen dynamics in a temperate forest landscape. Ecology. 74, 1579 - 1585.

Groffman, P.M., 1991. Ecology in nitrification and denitrification in soil evaluated at scales relevant to atmospheric chemistry, in Microbial production and consumption of greenhouse gases: Methane, nitrogen oxide and halomethanes, American Society of Microbiology, Washington, D.C., $201-217$.

Gundersen, P., Rasmussen, L. 1995. Nitrogen mobility in a nitrogen limited forest at Klosterhede, Denmark, Examined by $\mathrm{NH}_{4} \mathrm{NO}_{3}$ adition. Forest Ecology and Management. 71, $75-88$.

Gundersen, P., Emmet, BA., Kjonaas, OJ., Koopmans, CJ., and Tietema, A. 1998. Impact of nitrogen deposition on nitrogen cycling in forests: a synthesis of NITREX data. Forest Ecology Management.101, 37 - 56.

Hallbäcken, L. and Tamm, C.O. 1986. Changes in Soil Acidity from 1927 to 1982-1984 in a Forest Area of South-West Sweden. Scandinavian Journal of Forest Research. 1, 219 - 232.

Heal, O. W., Anderson, J. M. and Swift, M. J. 1997. Plant litter quality and decomposition: An historical overview. In. Cadish, G. and Giller, K. E. (eds), Driven by nature: plant litter quality and decomposition. CAB International, Wallingford, 3 - 30. 
Heisner, U. Wilpert, K.v. und Hildbrand, E.E. 2003. Vergleich aktueller Messungen zum Aziditätsstatus südwestdeutscher Waldböden mit historischen Messungen von 1927. Allgemeine Forst- und Jagdzeitung., 174., 2 - 3, 41 - 49.

Herlitzius, H. 1983. Biological decomposition efficiency in different woodland soils. Oecologia.110, $387-392$.

Houghton JT, Jenkins Cj, Ephraums JJ (eds), 1990. Climate change, the IPCC scientific assessment. Cambridge University Press, Cambridge.

Houghton, R.A., Davidson, E.A., Woodwell, G.M.,1998. Missing sinks, feedback, and understanding the role of terrestrial ecosystems in the global carbon balance. Global Biogeochemical Cycles 12, 25 - 34.

Ingestad, T. 1979. Mineral nutrient requirements of Pinus sylvestris and Picea abies seedlings. Physiologia Plantarum. 45, 373 - 380.

Johnson, DW., Ball, JT., Walker, RF. 1997. Effects of $\mathrm{CO}_{2}$ and nitrogen fertilisation on vegetation and soil nutrient content in Juvenile ponderosa pine. Plant and Soil. 190, 29 - 40.

Joergensen, R.G. 1996. The fumigation-extraction method to estimate soil microbial biomass: Soil Biology and Biochemistry. 28, 25 - 31.

Kaetterer, T., Reichstein, M., Andren, O., Lomander, A., 1998. Temperature dependence of organic matter decomposition: a critical review using literature data analysed with different models. Biology and Fertility of Soils. 27, 258 - 262.

Khanna, P. K. and Ulrich, B. 1991.Ecochemistry of Temperate Deciduous Forests. In E. Röhrig, B. Ulrich (eds.): Ecosystems of the world. 7, Elsevier, Amsterdam, London, New York, Tokyo, p.121 - 163.

Kirschbaum, M.U.F., 2000. Will changes in soil organic carbon act as a positive or negative feedback on global warming? Biogeochemistry. 48, 21 - 51. 
Kirschbaum M. U. F. 1995. The temperature dependence of soil organic matter decomposition, and the effect of global warming on soil organic $\mathrm{C}$ storage. Soil biology and Biochemistry. 27, $753-760$.

Killham, K. 1994. Soil Ecology. Cambridge University press, Cambridge p. 242.

Korotaev, A. A.,1992. Bodenverdichtung und Wurzelwachstum der Baeume. Forstarchiv. 63, 116 - 119.

Landsberg, JJ., Gower, ST. 1997. Applications of physiological ecology to forest management. New York: Academic Press.

Ljungström, M., and Stjernquist, I. 1995. Growth and nutrient dynamics of beech (Fagus sylvatica L.) seedlings in acid soils. Plant and Soil. 176, $171-181$.

Loftfield, N., Flessa, H., Augustin, J. Beese, F. 1997. Automated gas chromatographic system for rapid analysis of the atmospheric trace gases methane, carbon dioxide, and nitrous oxide. Journal of Environmental Quality. 26 (2), 560 - 564.

Lioyd, J., Taylor, J.A.,1994. On the temperature dependence of soil respiration. Functional Ecology. 8, 315 - 323.

Liu J-C and Trueby P 1989. Bodenanalytische Diagnose von K- und Mg-Mangel in Fichtenbestaenden (Picea abies Krast.) Zeitschrift für Pflanzenernährung und Bodenkunde. $152,307-311$.

Luxmoore, R.J., Grizzard and Strand, R.H. 1981. Nutrient retranslocation in the outer canopy and understory of aneastern deciduous forest. Forest Science. 27, 505 - 518.

Lukumbuzya, T. K., Fyles, J. W., and Cote, B. 1994. Effects of base cations fertilization on litter decomposition in a sugar maple forest in southern Quebec. Canadian Journal of Forest Research. 24, 447 - 452.

MacDonald, NW., Zak, DR., Pregitzer, KS. 1995. Temperature effects on kinetics of microbial respiration and net nitrogen and sulfur mineralization. Soil Science Society of America Journal. 59, 233 - 240.

Magill, AH., Aber, JD., Hendricks, JJ., Bowden, RD., Melillo, JM., Steudler, PA. 1997. 
Biogeochemical Response of Forest Ecosystems to Simulated Chronic Nitrogen Deposition. Ecological applications. 7 (2), 402 - 415.

Magill, AH., Downs, KJ., Nadelhoffer, RA., Hallet, RA., and Aber, JD. 1996. Forest ecosystem response to four years of chronic nitrate and Sulfate additions at Lead Mountain, Maine. Forest Ecology and Management. 84, 29 - 37.

Magill, A., Aber, JD., Berntson, G., McDowell, W., Nadelhoffer, K., Melillo, J., and Steudler, P. 2000. Long-term nitrogen additions and nitrogen saturation in two temperate forests.

Ecosystems. 3, $238-253$.

Mangel, K. and Kirkby, E.A. 1987. Principles of Plant Nutrition. International Potash Institute. Bern, 687 pp.

Marschner, H. 1986. Mineral nutrition of higher plants. Academic Press, London, 889 P.

Matschonat, G., Matzner, E. 1996. Soil chemical properties affecting $\mathrm{NH}_{4}{ }^{+}$sorption in forest soils. Zeitschrift für Pflanzenernährung und Bodenkunde. 159 (5), 505 - 511.

Matzner, E. 1989. Acid precipitation: case study Solling. Pages 95 - 115. Springer-Verlag, New York, USA.

McClaugherty, C.A., Pastor, J., Aber, J., and Melillo, j. M. 1985. Forest litter decomposition in relation to soil nitrogen dynamics and litter quality. Ecology. 66, 266 - 275.

McClaugherty, C., Berg, B., 1987. Cellulose, lignin and nitrogen concentrations as rate regulating factors in late stages of forest litter decomposition. Pedobiologia. 30, 101 - 112.

Mead, D.J. and Pritchett, W.L. 1975. Fertilizer movement in the slash pine ecosystem 1. Uptake of $\mathrm{N}$ and $\mathrm{P}$ and movement in the soil. Plant and Soil. 43, 451 - 465.

Mead, D.J. and Preston, C.M. 1994. Distribution and retranslocation of ${ }^{15} \mathrm{~N}$ in lodgepole pine over eight growing seasons. Tree Physiology. 4, 389 - 402.

Melillo, J. M., Aber, J. D. and Muratore, J. F. 1982. Nitrogen and lignin control of hardwood leaf litter decomposition dynamics. Ecology. 63, 621 - 626.

Meentemeyer, V. 1978. Macroclimate and lignin control of litter decomposition rates. 
Ecology. 59, 465 - 472.

Melin, J., Nommik, H., Lohm, U., Flower-Ellis, J. 1983. Fertilizer nitrogen budget in Scots pine ecosystem attained by using root-isolated plots and ${ }^{15} \mathrm{~N}$ tracer technique. Plant and Soil. 74, 249 - 263.

Millard, P. 1996. Ecophysiology of the Internal Cycling of Nitrogen for Tree Growth. Zeitschrift für Pflanzenernährung und Bodenkunde.159, 1 - 10.

Millard, P., Proe, M.F. 1991. Leaf demography and the seasonal internal cycling of nitrogen in sycamore (Acer Pseudoplatanus L.) seedlings in relation to nitrogen supply. New Phytologist. 117, 587 - 596.

Millard, P., Proe, M.F. 1993. Nitrogen uptake, partitioning and internal cycling in Picea sitchensis (Bong.) Carr. As influenced by nitrogen supply. New Phytologist. 125, 113 - 119.

Minotta, G., Pinzautti, S., 1996. Effects of light and soil fertility on growth, leaf chlorophyll content and nutrient use efficiency of beech (Fagus sylvatica L.) seedlings. Forest Ecology and Management. 86, 61 - 71.

Mochoge, B., and Beese, F. 1983. The behavior of nitrogen fertilizers in nutral and acid loess soils. II. Distribution and balance of ${ }^{15} \mathrm{~N}$-tagged nitrogen. Zeitschrift für Pflanzenernährung und Bodenkunde.146, 504 - 515.

Mulholland, P.J., Tank, J.L., Sanzone, D.M., Wollheim, W.M., Peterson, B.J., Webster, J.R. Meyer, J.L. 1999. Nitrogen Cycling in a Forest Stream Determined by a ${ }^{15} \mathrm{~N}$ Tracer addition. Ecological Monographs. 70 (3), 471 - 493.

Nambiar, E.K.S. and Fife, D.N. 1991. Nutrient retranslocation in temperate conifers. Tree Physiology. 9, 185 - 207.

Nambiar, E.K.S. and Bowen, G.D.1986. Uptake, distribution and retranslocation of nitrogen by Pinus radiata from $15 \mathrm{~N}$-labelled fertilizer applied to podzolized sandy soil. Forest Ecology and Management. 15, 269 - 284.

Naegele, W., and Conrad, R., 1990. Influence of soil pH on the nitrate reducing microbial populations and their potential to reduce nitrate to $\mathrm{NO}$ and $\mathrm{N}_{2} \mathrm{O}$, FEMS Microbial. Ecology. $74,49-58$.

Nadelhoffer, Kj., Downs, MR., Fry, B., Magill, A. and Aber, JD. 1999. Controls on N retention and exports in a frrtilized watershed. Environmental Monitoring and Assessment. 55 
(1): $187-210$.

Nadelhoffer, KJ., Downs, MR., Fry, B. Aber, JD., Magill, AH and Melillo, JM. 1995. The fate of ${ }^{15} \mathrm{~N}$-labelled nitrate additions to a northern hardwood forest in eastern Maine, USA.

Oecologia. 103, 292 - 301.

Nadelhoffer, KJ., Downs, MR., Fry, B. 1999. Sinks for ${ }^{15} \mathrm{~N}$-enriched additions to an oak forest and a red pine plantation. Ecological applications. 9, 72 - 86.

Nadelhoffer, KJ., Fry, B. 1994. Nitrogen isotope studies in forest ecosystems. In: Lajtha K, Michener R (eds) Stable isotope studies in ecology and environmental science. Blackwell. Oxford. PP 22 - 44.

Nadelhoffer, KJ., Aber, JD., Downs, MR., Fry, B., Melillo, JM. 1993. Biological sinks for nitrogen additions to a forested catchment. Experimental manipulations of biota and biogeochemical cycling in ecosystems: approach, methodologies, Findings (CEC Ecosystems Research Report no.(4) ECSC-EEC-EAEC. Brussels, Luxembourg. PP. 64 - 70.

Nadelhoffer, KJ., Aber, JD., Downs, MR., Fry, B. and Melillo, JM. 1992. Biological sinks for $\mathrm{N}$ additions to a forested catchment. In: Rasmussen L, Bridges $\mathrm{T}$ and Mathy $\mathrm{P}$ (EDS) Proceedings “ Experimental Manipulations of Biota and Biogeochemical Cycling in ecosystems", 18 - 20 May 1992 (pp 64 - 70). Copenhagen, Denmark.

Nadelhoffer, Kj., Aber, JD., Melillo, JM. 1984. Seasonal patterns of ammonium and nitrate uptake in nine temperate forest ecosystems. Plant and Soil. 80, 321 - 335.

Nadelhoffer, KJ., Emmett, BA., Gundersen, P., Kjonaas, OJ., Koopmans, CJ., Schleppi, P., Titema, A., Wright, RF. 1999. Nitrogen deposition makes a minor contribution to carbon sequestration in temperate forests. Nature. 398, 145 - 148.

Nihlgard, B. 1985. The ammonium hypothesis- an additional explanation to the forest decline in Europe. Ambio. 14, 2 - 8.

Nilsson, Lo., Wiklund, K. 1994. Nitrogen uptake in a Norway spruce stand following Ammonium-sulfate application, fertigation, irrigation, drought and nitrogen-free-fertilization. Plant and Soil. 164, 221 - 229.

NMELF (Nieedersächsisches Ministerium für Ernährung, Landwirtschaft und Forsten). 1996:

Waldentwicklung Solling. Fachgutachten. P. 14 - 15. 
Nommik, H. 1966. The uptake and translocation of fertilizer ${ }^{15} \mathrm{~N}$ in young trees of Scots Pine and Norway Spruce. Stud. For. Suec. 35, 18 pp.

Norden, U. 1994. Leaf litterfall concentrations and fluxes of elements in deciduous tree species. Scandinavian Journal of Forest Research. 9, 9 - 16.

Nodar,R., Acea, M.J., and Carballas, T., 1992. Microbial response to $\mathrm{Ca}(\mathrm{OH})_{2}$ treatment in a forest soil, FEMS Microbial Ecology, 86, 213 - 219.

Nylund, J-E., and Wallander, H. 1989. Effects of ectomycorrhiza on host growth and carbon balance in a semi-hydroponic cultivation system. New Phytologist. 112, 389 - 398.

Ockenden, I., Lott, JNA. 1998. Changes in the distribution of magnesium, Potassium, Calcium and Phosphorus during growth of Cucurbita seedlings. Journal of Experimental Botany. 39 (204), $973-980$.

Papen, H., and R. von Berg., Hellmann, B., and Rennenberg, H., 1991. The effect of experimental acid precipitation and liming on chemolithotrophic and heterotrophic nitrification in soils of the Hoeglwald, Forstwissenschaftliches Forsch., 39, 111 - 116.

Post, W.M., Pastor, J., Zinke, P.J.,Stangenberger, A.G. 1985. Global patterns of soil nitrogen storage. Nature. 317, 613 - 616.

Preston, C.M., Marshall, V.G., McCullough, K., Mead, D.J. 1990. Fate of ${ }^{15}$ N-labelled fertilizer applied on snow at two forest sites in British Colombia. Canadian Journal of Forest Research. $20,1583-1592$.

Preston, CM., and Mead, DJ. 1990. Distribution of N-15 labelled fertilizer applied on snow to lodgepöle pine in interior British Colombia, Canada, after one and eight growing seasons. Proc. International Symposium on the "Use of Stable Isotopes in plant nutrition, Soil Fertility and Environmental Studies" (pp 10 - 11). Vienna, Austria.

Ramanathan, V., R. J. Cicerone, H. B. Singh, and j. T. Kiehl, 1985. Trace gas trends and their potential role in climate change. Journal of Geophysical Research. 90, 5547 - 5566.

Raubuch, M., Joergensen, RG.,2002. C and net N mineralisation in a coniferous forest soil: 
the contribution of the temporal variability of microbial biomass $\mathrm{C}$ and N. Soil Biology and Biochemistry. 34 (6): 841 - 849.

Raubuch, M. 1998. The impact of moisture and temperature on adenylate content and adenylate energy of microbial communities in the litter of coniferous forest soils. Verhandlungen der Gesellschaft für Ökologie. 28, 415 - 419.

Reddy, K.R. and Patrick, Jr. 1975. Effect of alternate aerobic and anaerobic conditions on redox potential, organic matter decomposition and nitrogen loss in a flooded soil. Soil Biology and Biochemistry. 7, 87 - 94.

Reich, PB., Grigal, DF., Aber JD., Gower. 1997. Nitrogen mineralization and productivity in 50 hardwood and conifer stands on diverse soils. Ecology. 78, 335 - 347.

Rottmann, M., 1989. Wind- und Sturmschaeden in Wald: Beitraege zur Beurteilung d. Bruchgefaehrdung, zur Schadenvorbeugung und zur Behandlung sturmgeschaedigter Nadelholzbestaende. Sauerlaender Velag, Frankfurt (Main).

Robertson, G.P., 1989. Nitrification and denitrification in humid tropical ecosystems: potential controls on nitrogen retention. In Mineral Nutrients in tropical Forest and Savanna Ecosystems. Ed. J Protector. 55 - 69. Blackwell Scientific Publications, London.

Runion, GB., Entry, JA., Prior, SA., Mitchell, RJ., Rogers, HH. 1999. Tissue chemistry and carbon allocation in seedlings of Pinus palustris subjected to elevated atmospheric $\mathrm{CO}_{2}$ and water stress. Tree Physiology. 19, 329 - 335.

Sanger, L. J., Cox, P., Splatt, P., Whelan, M. J., and Andeson, J. M. 1996. Variability in the quality of Pinus sylvestris needles and litter from sites with different soil characteristics: lignin and phenylpropanoid signature. Soil Biology and Biochemistry. 28, 829 - 835.

Schimel D. S., braswell B.H., Holland E. A., McKeown R., Ojima D. S., Painter T. H., Parton W. J. and Townsend A. R. 1994. Climatic, edaphic, and biotic controls over storage and turnover of carbon in soils. Global Biogeochemical Cycles. 8, 279 - 293.

Schmaltz, J. 1966. Der Einfluß von Reservestoffen in den kotyledonen auf das wachstum von Buchensämlingen. Forstarchiv. 37, 138 - 139. 
Schimel, JP., and Firestone, M.K. 1989. Inorganic N incorporation by coniferous forest floor material. Soil Biology and Biochemistry. 21, 41 - 46.

Schlesinger, W.H., Andrews, J.A., 2000: Soil respiration and the global carbon cycle. Biogeochemistry. 48, 7 - 20.

Scott, N. A. and Binkley, D. 1997. Foliage litter quality and annual net N mineralization. Comparison across North American forest sites. Oecologia. 111, 151 - 159.

Sitaula, B.K., Bakken, L.R., 1993. $\mathrm{N}_{2} \mathrm{O}$ release from spruce forest soil, and relation with nitrification, $\mathrm{CH}_{4}$ uptake, temperature, moisture and fertilisation, Soil Biology and Biochemistry. 25, 1415 - 1421.

Skärby, L., Ro-Poulsen, H., Wellburn, F.A.M., and Sheppard, L.J. 1998. Impact of ozone on forests: a European perspective. New Phytologist. 139, 109 - 122.

Stanford, G., Van der Pol, R.A., Dzienia, S. 1975. Soil Science Society of America Processing. 29, $284-289$.

Stark, J. M., and Hart, S. C. 1996. Diffusion technique for preparing salt solution Kjeldahl digests, and persulfate digests for nitrogen-15 analysis. Soil Science Society America Journal. $60,1846-1855$.

Strickland, T. C., Sollins, p., Rudd, N., and Schimel, D.S. 1992. Rapid stabilization and mobilization of ${ }^{15} \mathrm{~N}$ in forest and range soils. Soil Biology and Biochemistry. 9, 849 - 855.

Suzuki, T., Kohno, K. 1983. Changes in nitrogen levels and free amino acids in rooting cuttings of mulberry (Morus alba). Physiologia Plantarum. 59 (3), 455 - 460.

Suner, A., Röhrig, E. 1980. Die Entwicklung der Buchennaturverjüngung in Abhängigkeit von der Auflichtung des Altbestandes. Forstarchiv, 51, 145 - 149.

Szymura, TH. 2003. Diffrences in elemental composition of silver fir seedlings from four different populations in eastern Poland. Forest Ecology and Management. 179, 497 - 505. Taylor, B. R., Parkinson, D. and Parsons, W. F. J. 1989. Nitrogen and lignin content as predictors of litter decay rates: a microcosm test. Ecology. 70, 97 - 104.

Termorshuizen, AJ. Ket, PC. 1991. Effects of ammonium and nitrate on mycorrhizal seedlings 
of Pinus-sylvestris. European Journal of Forest Pathology. 21 (6-7), 404 - 413.

Titema, A. 1998. Microbial carbon and nitrogen dynamics in coniferous forest floor material collected along a European nitrogen deposition gradient. Forest Ecology and Management. 101, $29-36$.

Tietema, A., Emmett, BA., Gundersen, P., Kjönaas, OJ., Koopmans, CJ. 1998. The fate of ${ }^{15} \mathrm{~N}-$ labelled nitrogen deposition in coniferous forests. Forest Ecology and Management. 101, 19 27.

Titema, A., Wessel, WW. 1992. Gross nitrogen transformations in the organic layer of acid forest ecosystems subjected to increased atmospheric nitrogen input. Soil Biology and Biochemistry. 24, 943 - 950.

Tietema, A. 1998. Microbial carbon and nitrogen dynamics in coniferous forest floor material collected along a European nitrogen deposition gradient. Forest Ecology and Management. 101, 29 - 36.

Tice, K. R., R. C. Graham, and H. B. Wood. 1996. Transformations of 2:1 phyllosilicates in 41 - year - old soils under oak and pine. Deoderama 70, 49 - 62.

Tyrrell, LE., Boerner, REJ. 1987. Larixlaricina and Picea mariana relationships among leaf lifespan, foliar nutrient patterns, nutrient conservation, and growth efficiency. Canadian Journal of Botany. 65 (8), $1570-1577$.

Tromp, J. 1983. Nutrient reserves of roots of fruit trees, in particular carbohydrates and nitrogen. Plant and Soil. 71, 401 - 413.

Ulrich, B. 1994. Nutrient and acid-base budget of central European forest ecosystems. In: Godbold, DL., Hüttermann, A. (eds) Effects of Acid Rain on Forest Ecosystems. John Wiley New York, pp 1 - 50.

Van Miegroet, H., and D. W. Cole. 1984. The impact of nitrification on soil acidification and cation leaching in a red alder ecosystem. Journal of Environmental Quality 13, 586 - 590.

Van Hees, A.F.M. and Clerkx, A.P.P.M. 2003. Shading and root-shoot relations in saplings of silver birch, pedunculate oak and beech. Forest Ecology and Management. 176, 439 - 448. 
Vitousek, P.M., Matson, P.A. 1985. Disturbance, nitrogen availability, and nitrogen losses in an intensively managed loblolly pine plantation. Ecology. 66, 1360 - 1376.

Vivin, P. Guehl, JM. 1997. Changes in carbon uptake and allocation patterns in Quercus robur seedlings in response to elevated $\mathrm{CO}_{2}$ and water stress: an evaluation with $\mathrm{C}-13$ labelling. Annals of Forest Science. 54, 597 - 610.

Wardle, D. A. and Lavelle, P. 1997. Linkages between soil biota, plant litter quality and decomposition.- In: Cadish, G. and Giller, K. E. (eds), Driven by nature: plant litter quality and decomposition. CAB International, wallingford, 107 - 124.

Wallander, H. 1995. A new hypothesis to explain allocation of dry matter between mycorrhizal fungi and pine seedlings in relation to nutrient supply. Plant and Soil. 168 - 169: 243 - 248.

Wallander, H. and Nylund, J-E. 1991. Effects of excess nitrogen on carbohydrate concentration and mycorrhizal development of Pinus sylvestris L. seedlings. New Phytologist. 119, 405 - 411.

Wallander, H. and Nylund, J-E. 1992. Effects of excess nitrogen and phosphorus starvation on the extramatrical myceliumof Pinus sylvestris L. ectomycorrhiza. New Phytologist. 120, 495 503.

Walbridge, M. R., and P. M. Vitousek. 1987. Phosphorous mineralization potentials in acid organic soils: processes affecting ${ }^{32} \mathrm{PO}_{4}$ isotope dilution measurements. Soil Biology and Biochemistry 19: 709 - 717.

Weier, K.L. Doran, J.W., Power, J.W. and Walters, D.T., 1993. Denitrification and the denitrogen/nitrous oxide ratio as affected by soil water, available carbon, and nitrate. Soil Science Society of America Journal. 57, 66 - 72.

Wolf, I., and Brumme, R. 2003. Dinitrogen and Nitrous Oxide formation in Beech Forest Floor and Mineral Soils. Soil Science Society of America Journal. 67, 1862 - 1868.

Wright, RF., and van Breeman, N. 1995. The Nitrex project: an introduction. Forest Ecology and Management. 71, 1 - 6 . 
Wright, R.F., Roelofs, J.G.M., Bredemeier, B., Blanck, K., Boxman, A.W., Emmett, B.A., Gundersen, P., Hultberg, H., Kjønaas, O.J., Moldman, F., Tietema, A., van Breemen, N. and van Dijk, H.F.G. 1995. NITREX responses of coniferous forest ecosystems to experimentally changed deposition of nitrogen. Forest Ecology and Management. 71, 163 - 169.

Wright, RF., Titema, A. 1995. Ecosystem response to 9 years of Nitrogen addition at Sogndal, Norway. Forest Ecology and Management. 71, 133 - 142.

Wyland, L. J., Jackson, L.E., Brooks, P. D. 1994. Eliminating nitrate interference during Kjeldahl digestion of soil extracts for microbial biomass determination. Soil Science Society of America Journal. 58, 357 - 360.

Xu, X.J., and Timmer, V.R. 1999. Growth and nitrogen nutrition of Chinese fir seedlings exposed to nutrient loading and fertilisation. Plant and Soil. 216, 83 - 91.

Zech, W., Suttner, T., Popp, E. 1985. Elemental analyses and physiological responses of forest trees in $\mathrm{SO}_{2}$-polluted areas of NE-Bavaria. Water, Air and Soil Pollution. 25, 175 - 183.

Zeller, B., Colin-Belgrand, M., Dambrine, E. and Martin, F. 2000. Decomposition of ${ }^{15}$ Nlabeled beech litter and fate of nitrogen derived from litter in a beech forest. Oecologia. 123, $550-559$.

Zezschwitz, E. 1980. Analytische Kennwerte typischer Humusformen westfälischer Bergwälder. Zeitschrift für Pflanzenernährung und Bodenkunde. 143, 692 - 700. 


\section{Acknowledgements}

I am so greatful to Prof. Dr. F. Beese for offering me an opportunity to do my Ph.D. in Institute of Soil Science and Forest Nutrition of Geoge-August University of Goettingen and for the kind supervision of my thesis. My sincere gratitude is to Prof. Dr. A. Hüttermann for taking over the second reference of my dissertation at the faculty of forest sciences and forest ecology. I am especially greatful to Dr. R. Brumme for precious advises and scientific support during my research work. I wish to thank all laboratory colleagues of Institute of Soil Science and Forest Nutrition especially Dr. N. Loftfield for technical assistance and support in analysing my soil samples. I would like to thank Mr. H. Mühlhan for technical assistance in instalation the equipments of the green house experiment. I am greatful to all colleagues of the Institute of Soil Science and Forest Nutrition for the nice atmosphere. I am highly greatful to my family especially my father Mr. G. R. Bagherzadeh and mother Mrs. B. Kormi for encourage and support me over the entire my education. I give my best thanks to my spouse Mrs. M. Afshari and my son Alireza for their great encourage and patience. 


\section{Curriculum vitae}

Name, first name:

Date of birth:

Place of birth:

Family status:

Nationality:

Education:

$1973-1978$

$1978-1980$

$1980-1984$

$1986-1988$

$1988-1990$

Professional activity:

Juni 1990 - Juni 1992

Juni 1992 - April 1995

Training:

April 1995 - Oktober 1995

Oktober 1995 - September 1996

Oktober 1996 - November 1997

April 1997 - Januar 2000

Juli 2000 - February 2004
Bagherzadeh Chaharjouee, Ali

21.09.1966

Mashhad

Married

Iran

Attendance at the primary school

Attendance at the guidance school

Attendance at the High school

with diploma in natural sciences

Study at the University of Mashhad in the field of Agriculture

Study at the University of Ahwaz in the field of soil science with the degree of Bachelor of Science

Military service

Work in the sugar factory of Fariman - Iran

German language course at the Goethe Institut in Goettingen with final examination of PNDS

Structure study at the technical University of Berlin in the field of sugar technology

Practical course at the sugar factory of Guestrow

Study at the Georg-August university of

Goettingen in the field of Agriculture - plant production with the degree of M.Sc. eng. agr.

Ph.D. study at the Georg-August university of Goettingen in the field of ecological soil science 